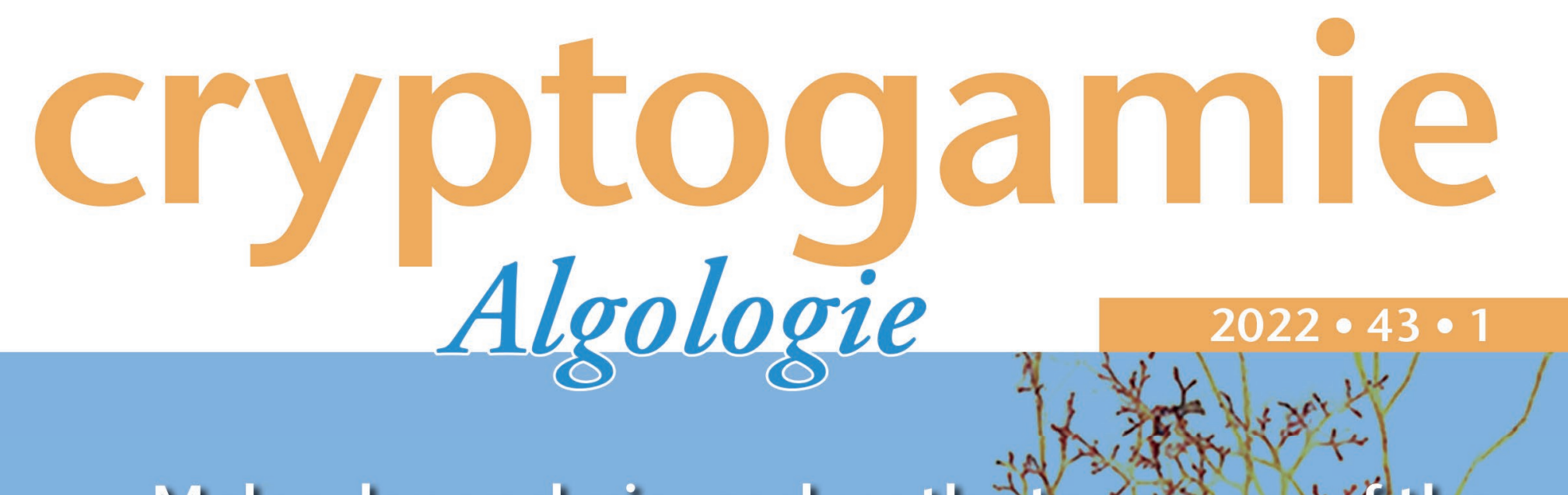

Molecular analysis resolves the tax o lo my off the Laurencia complex (Rhodomelacear Geramialíes)

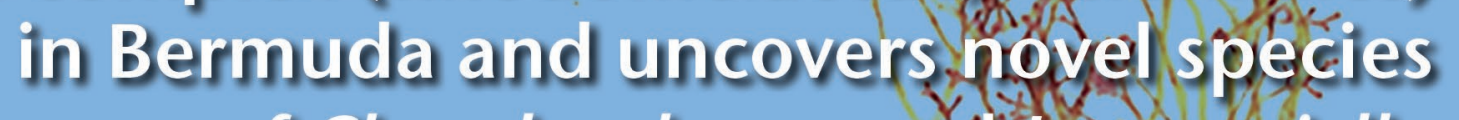
of Chondrophycus and daitrenciella

Thea R. POPOLIZIO, Craig W. SCHNEIDER, Walter M.JONGBLOED, Gary W. SAUNDERS \& Christopher E. 'LANE $y$,

se is

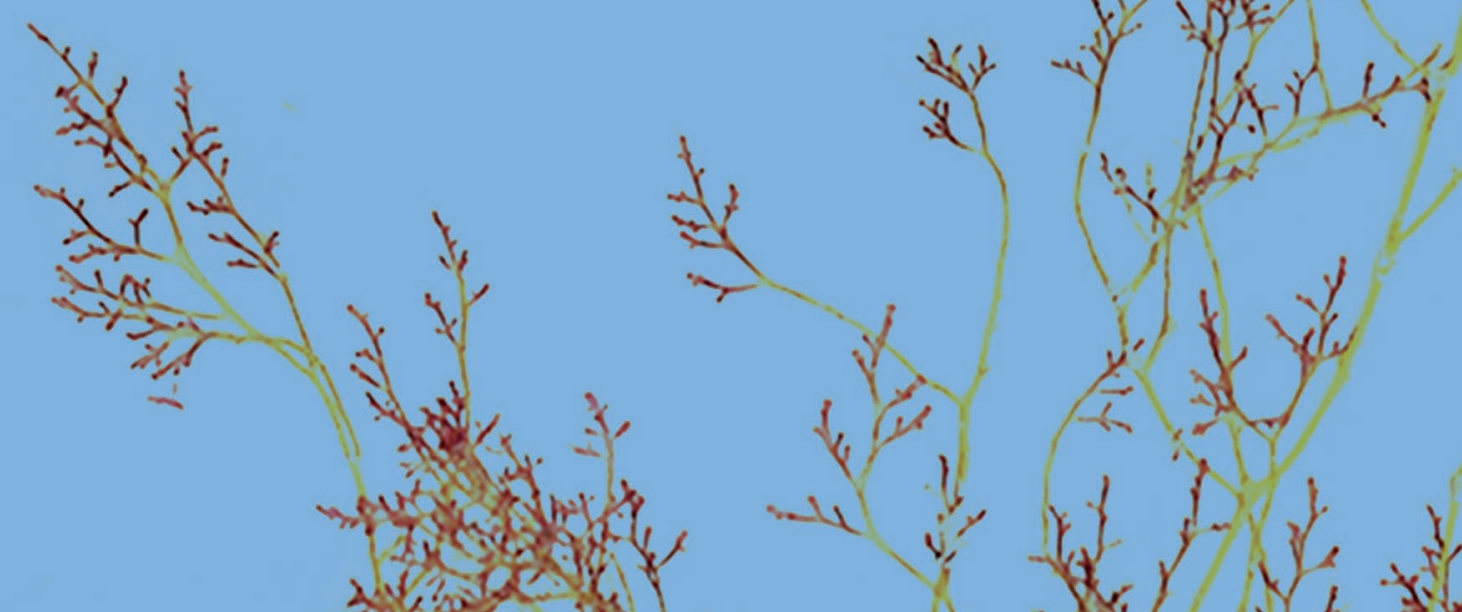

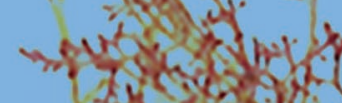
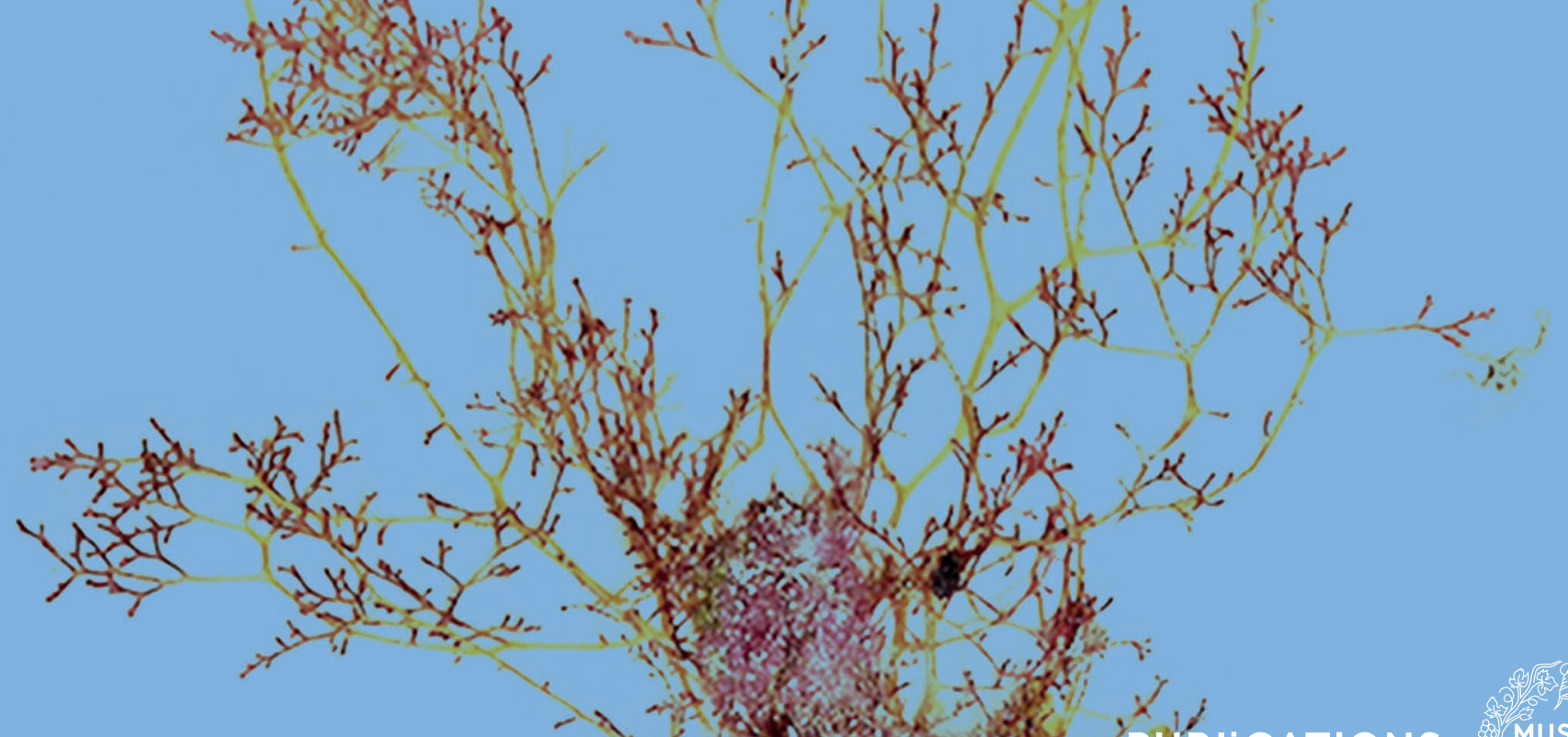

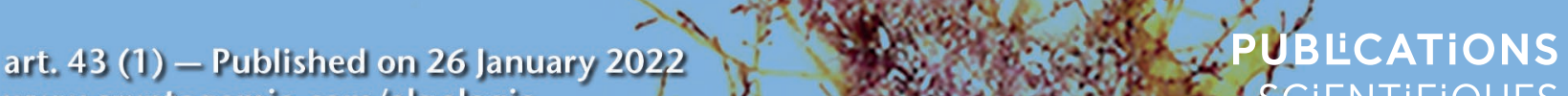
www. cryptogamie.com/algologje 
DiRECTEUR DE LA PUBLICATION / PUBLICATION DIRECTOR: Bruno DAVID

Président du Muséum national d'Histoire naturelle

RÉDACTRICE EN CHEF / EDITOR-IN-CHIEF : Line LE GALL

Muséum national d'Histoire naturelle

ASSISTANTE DE RÉDACTION / AsSISTANT EDITOR : Marianne SALAÜN (algo@cryptogamie.com)

MISE EN PAGE / PAGE LAYOUt : Marianne SALAÜN

RÉDACTEURS ASSOCIÉS / AsSOCIATE EDITORS

Ecoevolutionary dynamics of algae in a changing world

Stacy KRUEGER-HADFIELD

Department of Biology, University of Alabama, 1300 University Blvd, Birmingham, AL 35294 (United States)

Jana KULICHOVA

Department of Botany, Charles University, Prague (Czech Republic)

Cecilia TOTTI

Dipartimento di Scienze della Vita e dell'Ambiente, Università Politecnica delle Marche, Via Brecce Bianche, 60131 Ancona (Italy)

Phylogenetic systematics, species delimitation \& genetics of speciation

Sylvain FAUGERON

UMI3614 Evolutionary Biology and Ecology of Algae, Departamento de Ecología, Facultad de Ciencias Biologicas,

Pontificia Universidad Catolica de Chile, Av. Bernardo O’Higgins 340, Santiago (Chile)

Marie-Laure GUILLEMIN

Instituto de Ciencias Ambientales y Evolutivas, Universidad Austral de Chile, Valdivia (Chile)

Diana SARNO

Department of Integrative Marine Ecology, Stazione Zoologica Anton Dohrn, Villa Comunale, 80121 Napoli (Italy)

Comparative evolutionary genomics of algae

Nicolas BLOUIN

Department of Molecular Biology, University of Wyoming, Dept. 3944, 1000 E University Ave, Laramie, WY 82071 (United States)

Heroen VERBRUGGEN

School of BioSciences, University of Melbourne, Victoria, 3010 (Australia)

Algal physiology \& photosynthesis

Janet KÜBLER

California State University Northridge, Department of Biology, California State University, Northridge, CA 91330-8303 (United States)

Prokaryotic algae

Nico SALMASO

IASMA Research and Innovation Centre, Fondazione Mach-Istituto Agrario di S. Michele all'Adige, Limnology and River Ecology,

Via E. Mach, 1, 38010 San Michele all'Adige, Trento (Italy)

Vitor VASCONCELOS

Faculdade de Ciências da Universidade do Porto and CIIMAR, Rua do Campo Alegre, s/n, 4169-007 Porto (Portugal)

COUVERTURE / COVER:

Extraits d'éléments de la Figure 5 / Extracts of the Figure 5

Cryptogamie, Algologie est indexé dans / Cryptogamie, Algologie is indexed in:

- Aquatic Sciences \& Fisheries Abstracts Part I.

- Biological Abstracts

- Chemical Abstracts

- Current Contents

- Marine Science Contents Tables (FAO)

- Science Citation Index

- Publications bibliographiques du CNRS (Pascal).

Cryptogamie, Algologie est distribué en version électronique par / Cryptogamie, Algologie is distributed electronically by:

- BioOne ${ }^{\circledR}$ (http://www.bioone.org/loi/crya)

Cryptogamie, Algologie est une revue en flux continu publiée par les Publications scientifiques du Muséum, Paris

Cryptogamie, Algologie is a fast track journal published by the Museum Science Press, Paris

Les Publications scientifiques du Muséum publient aussi / The Museum Science Press also publishes: Adansonia, Geodiversitas, Zoosystema, Anthropozoologica, European Journal of Taxonomy, Naturae, Comptes Rendus Palévol, Cryptogamie sous-sections Bryologie, Mycologie.

Diffusion - Publications scientifiques Muséum national d'Histoire naturelle

CP $41-57$ rue Cuvier F-75231 Paris cedex 05 (France)

Tél. : 33 (0)1 40794805 / Fax: 33 (0)1 40793840

diff.pub@mnhn.fr / http://sciencepress.mnhn.fr

C) Publications scientifiques du Muséum national d'Histoire naturelle, Paris, 2022

ISSN (imprimé / print): 0181-1568 / ISSN (électronique / electronic): 1776-0984 


\title{
Molecular analysis resolves the taxonomy of the Laurencia complex (Rhodomelaceae, Ceramiales) in Bermuda and uncovers novel species of Chondrophycus and Laurenciella
}

\author{
Thea R. POPOLIZIO \\ Department of Biology, Salem State University, Salem, Massachusetts, 01970 (United States) \\ tpopolizio@salemstate.edu (corresponding author) \\ Craig W. SCHNEIDER \\ Walter M. JONGBLOED \\ Department of Biology, Trinity College, Hartford, Connecticut, 06106 (United States)
}

Gary W. SAUNDERS

Centre for Environmental \& Molecular Algal Research, Department of Biology, University of New Brunswick, Fredericton, NB E3B 5A3 (Canada)

Christopher E. LANE

Department of Biological Sciences, University of Rhode Island, Kingston, Rhode Island, 02881 (United States)

Submitted on 26 April 2021 | Accepted on 10 September 2021 | Published on 26 January 2022

Popolizio T. R., Schneider C. W., Jongbloed W. M., Saunders G. W. \& Lane C. E. 2022. - Molecular analysis resolves the taxonomy of the Laurencia complex (Rhodomelaceae, Ceramiales) in Bermuda and uncovers novel species of Chondrophycus and Laurenciella. Cryptogamie, Algologie 43 (1): 1-30. https://doi.org/10.5252/cryptogamie-algologie2022v43a1. http://cryptogamie.com/algologie/43/1

\section{ABSTRACT}

In the last decade, molecular tools have revealed a significant number of previously unrecognized taxa in Bermuda's marine flora, especially among the Rhodophyta. A number of species have been persistently misidentified based on morphological similarities to species described from other localities. Some have been assigned to existing taxa not previously reported for the islands, and many have been determined to be novel species. Of late, researchers have substantially modified the 'Laurencia complex' in several regions around the globe. Herein, we confirm the presence in Bermuda of five of the eight genera recognized in this complex - Laurencia J.V.Lamouroux, Chondrophycus (J.Tokida \& Y.Saito) Garbary \& J.T.Harper, Palisada (Yamada) K.W.Nam, Yuzurua (K.W.Nam) Martin-Lescanne and Laurenciella Cassano, Gil-Rodríguez, Senties, Díaz-Larrea, M.C.Oliveira \& M.T.Fujii, and discuss the species historically and presently known in the islands. Both $r b c \mathrm{~L}$ chloroplast sequences and COI-5P mitochondrial sequences support the recognition of at least two species for what has historically been labeled L. obtusa in Bermuda, these assigned to L. dendroidea J.Agardh and L. catarinensis Cordeiro-Marino \& M.T.Fujii in molecular analyses. We present two new species, Chondrophycus planiparvus Popolizio, C.W.Schneider \& C.E.Lane, sp. nov. and Laurenciella namii Popolizio,

KEY WORDS Bermuda,

ITS,

$r b c \mathrm{~L}$,

Rhodomelaceae, new species. C.W.Schneider \& C.E.Lane, sp. nov., the latter genetically distinct from L. marilzae (Gil-Rodriguez, Sentíes, Diaz-Larrea, Cassano \& M.T.Fujii) Gil-Rodriguez, Sentíes, Diaz-Larrea, Cassano \& M.T.Fujii, L. mayaimii Collado-Vides, Cassano \& M.T.Fujii and an undescribed species from Brazil. We also used ITS (rRNA) sequences to explore species limits for Laurencia catarinensis, L. dendroidea and L. microcladia Kützing. A full description of Laurencia microcladia, based on recent collections from Bermuda and the Caribbean Sea, is also included in this study. 


\begin{abstract}
RÉSUMÉ
L'analyse moléculaire résout la taxonomie du complexe Laurencia (Rhodomelaceae, Ceramiales) aux Bermudes et permet la découverte de nouvelles espèces de Chondrophycus et Laurenciella.

Au cours de la dernière décennie, les outils moléculaires ont révélé un nombre important de taxons précédemment non reconnus dans la flore marine des Bermudes, en particulier parmi les Rhodophytes. Un certain nombre d'espèces ont été constamment mal identifiées sur la base de similitudes morphologiques avec des espèces décrites dans d'autres localités. Certaines ont été attribuées à des taxons existants qui n’avaient pas été signalés auparavant pour les îles, et beaucoup ont été déterminées comme étant des espèces nouvelles. Ces derniers temps, les chercheurs ont considérablement modifié le «complexe Laurencia» dans plusieurs régions du monde. Dans cet article, nous confirmons la présence aux Bermudes de cinq des huit genres reconnus dans ce complexe - Laurencia J.V.Lamouroux, Chondrophycus (J.Tokida \& Y.Saito) Garbary \& J.T.Harper, Palisada (Yamada) K.W.Nam, Yuzurua (K.W.Nam) Martin-Lescanne et Laurenciella Cassano, Gil-Rodríguez, Senties, Díaz-Larrea, M.C.Oliveira \& M.T.Fujii, et nous discutons des espèces historiquement et actuellement connues dans les îles. Les séquences chloroplastiques $r b c$ et les séquences mitochondriales COI-5P soutiennent la reconnaissance d'au moins deux espèces pour le matériel qui a été historiquement étiqueté $L$. obtusa aux Bermudes, celles-ci étant assignées à $L$. dendroidea J.Agardh et $L$. catarinensis Cordeiro-Marino \& M.T.Fujii dans les analyses moléculaires. Nous présentons deux nouvelles espèces, Chondrophycus planiparvus Popolizio, C.W.Schneider \& C.E.Lane, sp. nov. et Laurenciella namii Popolizio, C.W.Schneider \& C.E.Lane, sp. nov., cette dernière étant génétiquement distincte de L. marilzae (Gil-Rodriguez, Sentíes, Diaz-Larrea, Cassano \& M.T.Fujii) Gil-Rodriguez, Sentíes, Diaz-Larrea, Cassano \& M.T.Fujii, L. mayaimii Collado-Vides, Cassano \& M.T.Fujii et d'une espèce non décrite du Brésil. Nous avons également utilisé les séquences ITS (rRNA) pour explorer les limites des espèces pour Laurencia catarinensis, $L$. dendroidea et $L$. microcladia Kützing. Une description complète de Laurencia microcladia, basée sur des collections récentes des Bermudes et de la mer des Caraïbes, est également incluse dans cette étude.

MOTS CLÉS
Bermudes,
COI-5P,
ITS,
rbcL,
Rhodomelaceae,
espèces nouvelles.
\end{abstract}

\section{INTRODUCTION}

The 'Laurencia complex' is a diverse sub-grouping of red algae in the family Rhodomelaceae (Tribe Laurencieae Schmitz 1889) found in tropical and temperate seas worldwide and contains 232 currently accepted species (Guiry \& Guiry 2020). In the past several decades, this group has received substantial attention from phycologists around the world due to its convoluted taxonomy and nomenclature (e.g., Fujii et al. 2006; Cassano et al. 2009, 2012b; Martin-Lescanne et al. 2010; Metti et al. 2015). Within the complex (and in addition to Laurencia sensu stricto) the genus Osmundea Stackhouse has been resurrected (Nam et al. 1994), Chondrophycus (J.Tokida \& Y.Saito) Garbary \& J.T.Harper (Garbary \& Harper 1998) and Yuzurua (K.W.Nam) Martin-Lescanne (Martin-Lescanne et al. 2010) have been elevated to generic status, and four new genera have been described - Palisada (Yamada) K.W.Nam (Nam 2007), Laurenciella Cassano, Gil-Rodríguez, Senties, Díaz-Larrea, M.C.Oliveira \& M.T.Fujii (Cassano et al. 2012b), Corynecladia J.Agardh (Metti et al. 2015; Cassano et al. 2019) and Ohelopapa F.Rousseau, Martin-Lescanne, Payri \& L.Le Gall (Rousseau et al. 2017). Members of the 'Laurencia complex' are known to exhibit considerable morphological plasticity, making them challenging to diagnose using morphology alone. Each of the genera, however, has been shown to form well-supported monophyletic clades in multiple publications, except for the taxon-rich genus Laurencia (138 spp.). This group is in need of extensive molecular and morphological analysis and, likely, additional re-organization.
As a genus, Laurencia Kutzing has already been significantly modified by molecular-assisted alpha taxonomy (MAAT) (e.g. Gil-Rodríguez et al. 2009; Cassano et al. 2012a, b; ColladoVides et al. 2018). Erected by Lamouroux (1813: 131-132) for only eight species, L. obtusa (Hudson) J.V.Lamouroux was later lectotypified as the generitype (Schmitz 1889). In his monograph of Laurencia, Yamada (1931) separated the genus into four sections based on morphological and anatomical features. Saito (1967) segregated Laurencia sensu lato into two subgenera, designating these Chondrophycus and Laurencia based on differences in tetrasporangial arrangement and the presence or absence of secondary pit connections. Decades later, the genus Osmundea (Stackhouse 1809) was resurrected by Nam et al. (1994) within the complex and distinguished from Laurencia by the reproductive characters of tetrasporangial and spermatangial branch origin. By this time, it was also established that Laurencia possessed four pericentral cells, whereas the other genera had only two. Using morphological cladistics, Garbary \& Harper (1998) elevated the subgenus Chondrophycus to generic rank as sister to Osmundea based primarily on the presence of two (rather than four) pericentral cells in vegetative axes and trichoblast-type spermatangial development. Osmundea exhibits filament-type spermatangial development. Many of the species nested within the Chondrophycus clade resolved by Garbary \& Harper (1998) have since been transferred to Palisada, a genus proposed and later validated by Nam (2007) based on Yamada's (1931) section Palisadae of Laurencia, with tetrasporangial development unique from that of Chondrophycus. Martin-Lescanne et al. 
(2010) segregated Yuzurua from Palisada sensu stricto on molecular evidence, adding a fifth genus to the complex. The authors determined the morphological traits of Yuzurua to mainly overlap with those of Palisada, but with secondary pit connections between cortical cells in the former, and lacking the characteristic palisade-like cells of the latter genus. The genus Laurenciella was added to the complex for a molecularly distinct clade that is entirely morphologically cryptic with its sister genus Laurencia sensu stricto (Cassano et al. 2012b). The genus Corynecladia (as Coronaphycus Metti) was recognized for an independent clade that included Laurencia elata (C.Agardh) Hooker f. \& Harvey and is morphologically characterized by development of an extensive secondary cortex at the base of the thallus (Metti et al. 2015). The name was emended to Corynecladia when molecular evidence placed C. elata (C.Agardh) Cassano, M.C.Oliveira \& M.T.Fujii and C. nova (Metti) Cassano, M.C.Oliveira \& M.T.Fujii in a clade with the generitype Corynecladia clavata (Sonder) J.Agardh (Cassano et al. 2019). Most recently, Laurencia flexilis Setchell (Rousseau et al. 2017) was designated as the generitype Ohelopapa flexilis F.Rousseau, Martin-Lescanne, Payri \& L.Le Gall for a new genus (Rousseau et al. 2017), creating a further subdivision in the Laurencia complex.

Members of the Laurencia complex are distinguished from the closely related genus Chondria C.Agardh by both vegetative and reproductive characters. Chondria displays five pericentral cells per axial cell (often only obvious at the apices); genera in the Laurencia complex produce either two or four (Womersley 2003). Spermatangial plates form in Chondria; alternatively, in the Laurencia complex male gametangia develop from trichoblasts located within apical pits (Nam 1999).

Several workers in the past two decades have provided a phylogenetic basis for the re-organization of the Laurencia complex within a broad global context and have introduced a great number of new or reinstated genera (Cassano et al. 2009; Gil-Rodriguez et al. 2009; Martin-Lescanne et al. 2010). Comprehensive surveys of this complex using molecular tools are less common for specific localities like Bermuda, but the results are particularly interesting when compared to historical accounts of the islands' flora. Reports of Laurencia in Bermuda first appeared in the literature in the mid 19th century, the earliest by Alexander F. Kemp (1857), who included L. obtusa and $L$. papillosa C.Agardh (now Palisada perforata (Bory) K.W.Nam). Laurencia obtusa (type locality = England) was subsequently recorded from the islands by workers over the next century (Rein 1873; Dickie 1874; Hemsley 1884; Murray 1888; Collins et al. 1916 [as Phycotheca Boreali-Americana XLII, no. 2092]; Collins \& Hervey 1917; Howe 1918; Tandy 1936; Bernatowicz 1952) followed by later $20^{\text {th }}$ century accounts (see Schneider 2003). Laurencia obtusa var. crucifera Kützing was reported by Dickie (1874), and var. gracilis (C.Agardh) Zanardini by Collins \& Hervey (1917). Collins \& Hervey (1917) reported L. paniculata J.Agardh from Bermuda, and this species is presently regarded as a junior synonym of L. obtusa. Rein (1873) provided the first account of Yuzurua poiteaui (J.V.Lamouroux) Martin-Lescanne (as L. gemmifera Harvey). Howe (1918) included L. intricata J.V.Lamouroux, L. microcladia Kützing, and Palisada corallopsis
(Montagne) Sentíes, M.T.Fujii \& Díaz-Larrea [as L. corallopsis (Montagne) M.Howe] in his survey of the islands' flora. Almost a century later, Schneider $\&$ Lane $(2005,2007)$ and Schneider et al. (2010) added L. decumbens Kützing, Yuzurua iridescens (M.J.Wynne \& D.L.Ballantine) Sentíes, M.J.Wynne, Cassano, Gil-Rodriguez \& M.T.Fujii [as Chondrophycus iridescens (M.J.Wynne \& D.L.Ballantine) Garbary \& J.T.Harper] and L. caraibica P.C.Silva to the Bermuda flora.

The present study provides the molecular and morphological evidence needed to establish Laurencia dendroidea J.Agardh, L. catarinensis Cordeiro-Marino \& M.T.Fujii, Palisada flagellifera (J.Agardh) K.W.Nam, and novel species of Laurenciella and Chondrophycus as constituents of the Laurencia complex in the Bermuda flora. We also verify previous reports of the following members of this tribe: Laurencia intricata J.V.Lamouroux, L. microcladia Kützing, Palisada perforata (Bory) K.W.Nam, P. corallopsis, Yuzurua poiteaui (J.V.Lamouroux) MartinLescanne and $Y$. iridescens, and distinguish the formerly synonymized P. cervicornis (Harvey) Collado-Vides, Cassano \& M.T.Fujii from P. corallopsis in Bermuda. Unfortunately, our attempts to obtain sequence data from archival material of L. caraibica and L. decumbens collected in Bermuda in the recent past have been unsuccessful.

\section{METHODS}

Collections were made in shallow water $(0-3 \mathrm{~m})$ or via scuba (to $23 \mathrm{~m}$ ), and site locations were taken using a Garmin ${ }^{\text {TM }}$ eTrex H (Olathe, Kansas, United States). A portion of each specimen used for DNA analysis was dried on silica gel, and the remainder of the thallus was pressed onto herbarium paper as a permanent voucher. Selected fragments were preserved in $4-5 \%$ formaldehyde in seawater for anatomical study. Sections were mounted in 30\% corn syrup with acidified $1 \%$ aniline blue in a ratio of 20:1 with a few drops of formaldehyde as a medium preservative. Live specimens chosen for DNA analysis were photographed using a Canon Powershot $s 90$ digital camera (Canon Inc., Tokyo, Japan), and dried herbarium specimens were scanned on an HP 309a Photosmart Premium scanner (Hewlett-Packard Company, Palo Alto, California, United States). Photomicrographs were taken using Zeiss Axioskop 40 microscope (Oberkochen, Germany) equipped with a model 11.2 Spot InSight 2 digital camera (Diagnostic Instruments, Sterling Heights, Michigan, United States). The digital images were composed in Adobe Photoshop ${ }^{\mathrm{Tm}} \mathrm{CS} 6 \mathrm{v}$. 13.0.1 (Adobe Systems, San Jose, California, United States). Voucher specimens of some numbers are deposited in KIRI, $\mathrm{MICH}, \mathrm{NY}$, the Bermuda Natural History Museum (BAMZ) and Herbarium C.W. Schneider. Herbarium abbreviations follow the online Index Herbariorum (http://sweetgum.nybg.org/ ih/) and standard author initials are from Brummitt $\&$ Powell (1992). The Phycotheca Boreali-Americana (P.B.-A.) exsiccata cited here is part of CWS' personal herbarium.

Silica-dried samples for DNA analysis were ground in liquid nitrogen and stored at $-20^{\circ} \mathrm{C}$. DNA was extracted from 0.1-0.5 $\mu$ l ground material using a GenElute Plant Genomic 
Miniprep Kit according to manufacturer protocol (SigmaAldrich, St. Louis, Missouri, United States) with $500 \mu \mathrm{l}$ of modified lysis solution $(50 \mu \mathrm{l} 10 \%$ TWEEN 20 , and $5 \mu \mathrm{l}$ of $20 \mathrm{mg} / \mathrm{ml}$ Proteinase $\mathrm{K}$ added), as well as $1 \mathrm{hr} 23^{\circ} \mathrm{C}$ incubation followed by a $20 \mathrm{~min}$ incubation on ice (Saunders \& Druehl 1993).

DNA was amplified via polymerase chain reaction (PCR) with the Takara Ex-Taq DNA polymerase kit (PanVera, Madison, WI, United States) in an Eppendorf AG Mastercycler epGradient thermal cycler (Eppendorf, Hamburg, Germany). To assign all specimens to species groups, two oligonucleotide primers were used for both sequencing and amplification of the COI-5P barcode marker (the 5' region of the cytochrome $c$ oxidase subunit I gene), GWSFn (Le Gall \& Saunders 2010) and GWSRx (Saunders \& McDevit 2012). A denaturation cycle of $94^{\circ} \mathrm{C}$ for 4 min was followed by $38-42$ cycles of $94^{\circ} \mathrm{C}$ for $1 \mathrm{~min}, 45^{\circ} \mathrm{C}$ for $1 \mathrm{~min}, 72^{\circ} \mathrm{C}$ for $1 \mathrm{~min}$ and a final extension of $72^{\circ} \mathrm{C}$ for $7 \mathrm{~min}$. Several specimens were selected for additional sequencing of the plastid-encoded RuBisCO $(r b c \mathrm{~L})$ operon. Four oligonucleotide primers were used for both amplification and sequencing of two overlapping fragments: forward- RR1 (5' ATGTCTAACTCTGTAGAAG 3') and reverse- RR4 (5' TTCAGCTCTTTCATACAT 3') and forward- RrIf (5' TCTCAGCCTTTTATGCGTTG 3') and reverse- Rrr (5'ATCTCACTATTCTATACTCC 3'). A denaturation cycle of $94^{\circ} \mathrm{C}$ for 4 min was followed by 35 cycles of $94^{\circ} \mathrm{C}$ for $1 \mathrm{~min}, 47^{\circ} \mathrm{C}$ for $1 \mathrm{~min}, 72^{\circ} \mathrm{C}$ for $2 \mathrm{~min}$, and a final extension of $72^{\circ} \mathrm{C}$ for $7 \mathrm{~min}$. Amplified DNA was treated with the QIAquick PCR Purification Kit following the manufacturer's protocol (Qiagen Redwood City, California, United States), and the purified PCR product was sequenced at the Rhode Island Genomics and Sequencing Center using the Applied Biosystems Inc. 3130xl Genetic Analyzer (Life Technologies, Grand Island, New York, United States). Specimens used in COI-5P and $r b c \mathrm{~L}$ analyses are recorded in Appendix 1.

To compare intraspecific vs. interspecific sequence distances in three of our Laurencia taxa, allowing us to assess species boundaries not clearly resolved with COI-5P and $r b c \mathrm{~L}$, we sequenced the internal transcribed spacer region of nuclear ribosomal cistron (ITS). ITS amplification and sequencing followed Saunders \& Moore (2013) using the primers P1 and Harv4 for amplification and sequencing, as well as the internal primers P5 and R1 for sequencing. The resulting 18 ITS sequences were aligned using MUSCLE (multiple sequence comparison by log-expectation) in Geneious Prime (v. 2020.1 available from http://www.geneious.com) and adjusted by eye where needed. Sequence comparison for the ITS was based only on nucleotide substitutions between/among species with the insertions and deletions (indels) removed prior to barcode gap analysis. Specimens used in ITS analysis are recorded in Appendix 2.
COI-5P sequences from representative species within the Laurencia complex, including those available through GenBank and newly determined here (Appendix 1), were included in an alignment using MUSCLE (in Geneious v. 9.0.5). The COI-5P alignment was analyzed in Geneious using the Species Delimitation tool to calculate intraspecific variation and nearest neighbor distances (barcode gap) (Table 1). To compare intraspecific variation and nearest neighbor distances in a second gene, we repeated the alignment and distance analysis described above using $r b c \mathrm{~L}$ sequence data from our collected specimens and from GenBank (Appendix 1 and Table 1). These data were used to demarcate genetic species groups.

Following barcode gap analyses, an alignment was constructed with MUSCLE (in Geneious v. 9.0.5) using fulllength $r b c \mathrm{~L}$ (the RuBisCO large subunit gene) sequences for one representative of each genetic species. In some instances, multiple specimens from our collections representing the same species were included in the analysis because they were from different geographic locations (i.e., Bermuda, Florida and/or the Caribbean). To place our western Atlantic specimens in a broader context, all relevant GenBank data (Appendix 1) for the Laurencia complex were added to the alignment (generated using MUSCLE in Geneious v. 9.0.5), along with several other taxa in the Rhodomelaceae as outgroups. The best model of evolution for the $r b c \mathrm{~L}$ (132 taxa, 1217 sites) was determined in jModelTest 2 (volume 2.1.10; Darriba et al. 2012). The selected phylogenetic model $(\mathrm{GTR}+\mathrm{I}+\mathrm{G})$ was used to complete maximum likelihood (ML) and Bayesian (BI) analyses. In both analyses the data set was partitioned by codon. The $r b c \mathrm{~L}$ maximum likelihood phylogeny was estimated using the RAxML graphical user interface (Silvestro \& Michalak 2012) with branch support calculated using 1000 bootstrap replicates. Bayesian analysis of $r b c \mathrm{~L}$ was conducted in MrBayes v.3.2.2 (Ronquist \& Huelsenbeck 2003) and run with four parallel chains of the Markov chain Monte Carlo (three heated + one cold) starting with a random tree and sampling at intervals of 1000 generations for four million generations. After 1 million generations the standard deviation of split frequencies reached 0.01 and likelihood scores had stabilized, thus the initial 1000 trees were discarded as the burn-in. Posterior probabilities (PP) were estimated based on the remaining trees. The generated tree was manipulated for presentation (Fig. 1) using FigTree v1.4.4 software (http:// tree.bio.ed.ac.uk/software/figtree/).

\section{RESULTS/SYSTEMATICS}

Our DNA barcode (COI-5P) analysis included 243 sequences (ranging from 458 to 617 base pairs [bp]) from members of the Laurencia complex; 170 of these (70\%) were generated for this study from specimens collected in Bermuda, the

FIG. 1. - Maximum likelihood tree topology derived from analysis of $r b c L$ sequences with bootstrap values $(\geq 70)$ and Bayesian posterior probabilities ( $\geq 0.95)$ appended, respectively. A dash (-) indicates values lower than these thresholds for that analysis, while an asterisk (*) indicates strong support (>98/1) for both metrics. Branches leading to an unsupported node (i.e., support values below the ML and BI thresholds) are colored gray. Sequences from taxa appearing in boldface type were newly generated in this study. 
Ohelopapa flexilis Tahit

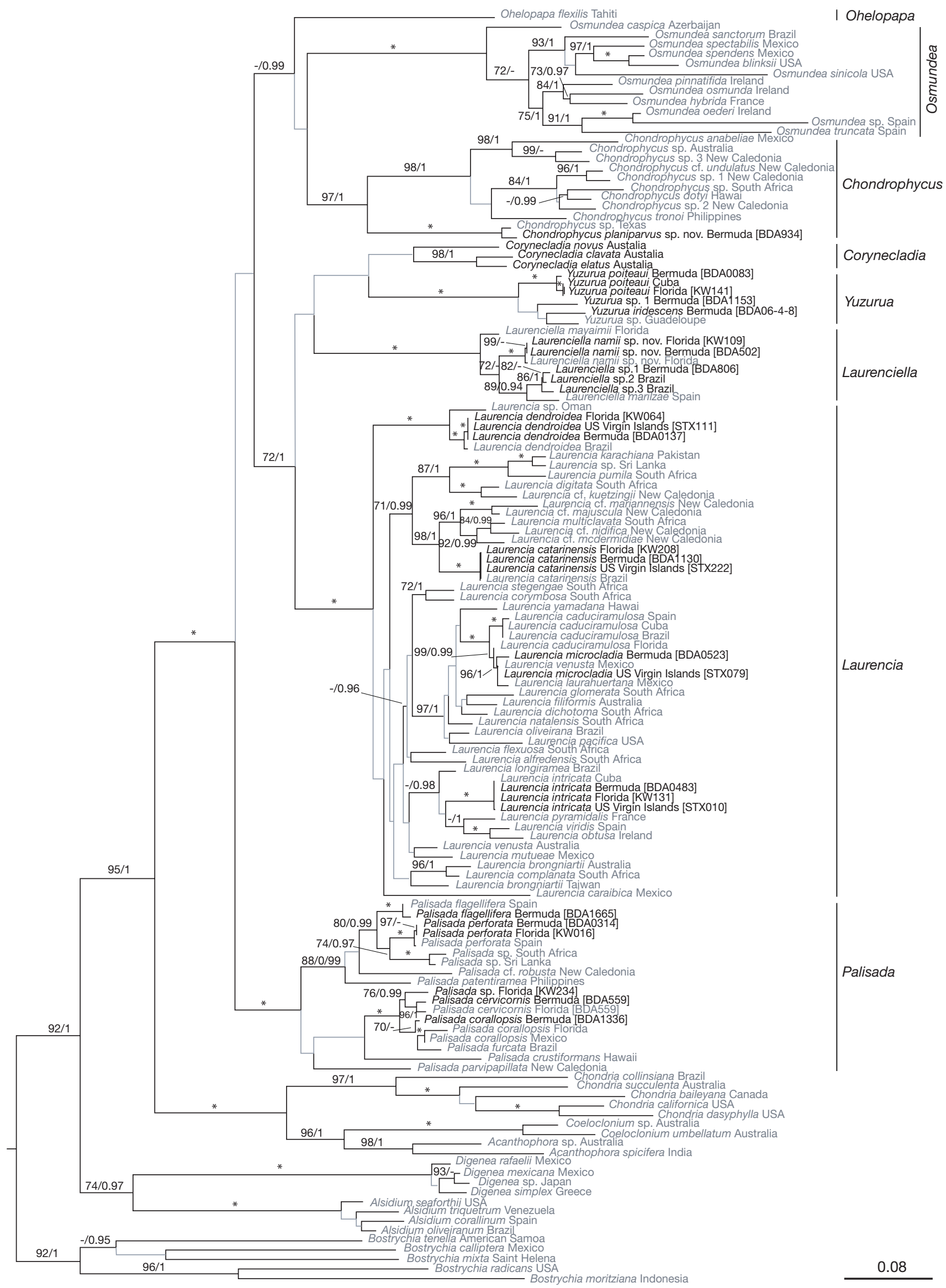


TABLE 1. - Intraspecific divergence and distance to nearest neighbor in COI-5P and $r b c \mathrm{~L}$ for taxa within the Laurencia complex included in this study. a-Includes Chondrophycus sp. (Texas) b-Includes Laurencia sp. (Sri Lanka) c-Includes taxa currently ascribed to L. venusta (Mexico), L. caduciramulosa ( United States) and L. laurahuertana. When these sequences are excluded, the maximum intraspecific divergence for L. microcladia is $0.4 \%$.d-Includes Laurenciella sp. 2 (Brazil) * Species with new sequence data from collections made in Bermuda, St. Croix, and/or the Florida Keys. For both COI-5P and $r b c L$ genes, we selected one specimen of each newly sequenced species and geographic location for deposit in GenBank. The complete datasets for each gene can be shared upon request.

\begin{tabular}{|c|c|c|c|c|c|c|c|c|}
\hline \multirow[b]{2}{*}{ Species } & \multicolumn{4}{|c|}{ COI-5P } & \multicolumn{4}{|c|}{ rbcL } \\
\hline & n & $\begin{array}{l}\text { Max intra- } \\
\text { specific } \\
\text { divergence (\%) }\end{array}$ & Nearest neighbor & $\begin{array}{l}\text { Distance to } \\
\text { nearest } \\
\text { neighbor (\%) }\end{array}$ & & $\begin{array}{r}\text { Max intraspecific } \\
\text { divergence (\%) }\end{array}$ & Nearest neighbor & $\begin{array}{l}\text { Distance to } \\
\text { nearest } \\
\text { neighbor (\%) }\end{array}$ \\
\hline Chondrophycus & - & - & - & - & - & - & - & - \\
\hline C. dotyi & 1 & - & C. planiparvus sp. nov. & 9.3 & 1 & - & C. sp. 1 South Africa & 3.8 \\
\hline C. planiparvus sp. nov.* & 1 & - & C. undulatus & 8.8 & $2 a$ & 0.5 & C. sp. Australia & 9.5 \\
\hline C. undulatus & 4 & 0.4 & C. planiparvus sp. nov. & 8.8 & 1 & - & C. sp. 1 New Caledonia & 2.1 \\
\hline Corynecladia & - & - & - & - & - & - & - & - \\
\hline C. clavata & 1 & - & O. flexilis & 10.5 & 1 & - & C. elatus & 2.5 \\
\hline Laurencia & - & - & - & - & - & - & - & - \\
\hline L. catarinensis* & 24 & 0.5 & L. karachiana & 5.2 & 6 & 0.06 & L. majuscula & 4.2 \\
\hline L. dendroidea* & 60 & 2.4 & L. intricata & 9.3 & 7 & 0.5 & L. longiramea & 5.5 \\
\hline L. intricata* & 10 & 0.1 & L. longiramea & 5.2 & 8 & 0.3 & L. longiramea & 3.7 \\
\hline L. karachiana & 1 & - & L. catarinensis & 5.2 & $2 b$ & 0.3 & L. pumila & 2.1 \\
\hline L. longiramea & 1 & - & L. pacifica & 4.2 & 1 & - & L. pyramidalis & 2.9 \\
\hline L. mcdermidiae & 4 & 0.8 & L. intricata & 7.9 & 1 & - & L. nidifica & 2.5 \\
\hline L. microcladia* & 19 & 0.5 & L. nidifica & 4.6 & $5 c$ & 0.5 & L. caduciramulosa & 1.2 \\
\hline L. nidifica & 5 & 1.2 & L. microcladia & 4.6 & 1 & - & L. mcdermidiae & 2.5 \\
\hline L. nipponica & 3 & 0.4 & L. satoi & 3.7 & - & - & - & - \\
\hline L. obtusa & 1 & - & L. viridis & 2.8 & 1 & - & L. viridis & 2.0 \\
\hline L. pacifica & 2 & 0.3 & L. longiramea & 4.2 & 1 & - & L. catarinensis & 7.3 \\
\hline L. pyramidalis & 4 & 0.3 & L. longiramea & 6.2 & 2 & 0.08 & L. viridis & 3.3 \\
\hline L. satoi & 1 & - & L. nipponica & 3.7 & 1 & - & - & - \\
\hline L. viridis & 3 & 0.2 & L. obtusa & 2.8 & 2 & 0.5 & L. obtusa & 1.8 \\
\hline Laurenciella & - & - & - & - & - & - & - & - \\
\hline L. marilzae & 3 & 1.1 & L. sp.1Bda & 6.0 & 3 & 0.4 & L. sp. 3 Brazil & 1.6 \\
\hline L. mayaimii & 1 & - & L. marilzae & 8.7 & 1 & - & L. namii sp. nov. & 3.6 \\
\hline L. namii sp. nov.* & 14 & 0.4 & L. mayaimii & 9.4 & 3 & 0.2 & L. marilzae & 3.9 \\
\hline L. sp. 1Bda* & 1 & - & L. marilzae & 6.0 & $2 d$ & 0.4 & L. sp. 3 Brazil & 0.9 \\
\hline Ohelopapa & - & - & - & - & - & - & - & - \\
\hline O. flexilis & 1 & - & C. clavata & 10.5 & 1 & - & L. mcdermidiae & 12.5 \\
\hline Osmundea & - & - & - & - & - & - & - & - \\
\hline O. hybrida & 1 & - & O. pinnatifida & 7.1 & 2 & 0.6 & O. pinnatifida & 5.1 \\
\hline O. osmunda & 1 & - & O. pinnatifida & 5.7 & 2 & 0.05 & O. pinnatifida & 4.6 \\
\hline O. spectabilis & 6 & 0.8 & O. hybrida & 9.7 & 4 & 0.3 & O. splendens & 4.2 \\
\hline O. splendens & 2 & 0.5 & O. pinnatifida & 12.1 & 3 & 0.6 & O. blinksii & 1.7 \\
\hline O. pinnatifida & 1 & - & O. osmunda & 5.7 & 3 & 0.2 & O. osmunda & 4.6 \\
\hline Palisada & - & - & - & - & - & - & - & - \\
\hline P. cervicornis* & 2 & 0 & Palisada & 4.5 & 3 & 0.7 & P. sp. 1Fla & 2.0 \\
\hline P. corallopsis* & 2 & 0 & Palisada & 3.9 & 4 & 0.6 & P. furcata & 2.1 \\
\hline$P$. flagellifera* & 6 & 1.3 & P. parvipapillata & 6.3 & 5 & 0.2 & P. perforata & 3.0 \\
\hline P. parvipapillata & 1 & - & P. flagellifera & 6.3 & - & - & - & - \\
\hline P. perforata* & 28 & 0.6 & $P$ flagellifera & 6.7 & 16 & 0.2 & $P$. sp. South Africa & 2.6 \\
\hline P. sp. 1Fla* & 3 & 0 & P. corallopsis & 3.9 & 3 & 0.0 & P. cervicornis & 2.0 \\
\hline Yuzurua & - & - & - & - & - & - & - & - \\
\hline Y. iridescens* & 2 & 0 & Y. poiteaui & 6.9 & 3 & 0.0 & Y. sp. Guadeloupe & 3.7 \\
\hline Y. poiteaui* & $1 \overline{1}$ & 0.8 & Yuzurua & 5.7 & 10 & 0.2 & Y. sp. Guadeloupe & 5.3 \\
\hline Y. sp. $1 \mathrm{Bda}^{*}$ & 1 & - & Y. poiteaui & 5.7 & 1 & - & Y. iridescens & 4.4 \\
\hline
\end{tabular}

Florida Keys and St. Croix, USVI. The remaining 73 COI5P sequences were downloaded from GenBank (Appendix 1). Maximum intraspecific divergence for COI-5P based on our data combined with sequences available in GenBank ranged from $0-1.3 \%$ for all species except Laurencia dendroidea (2.4\%; Table 1). Interspecific variation for COI-5P ranged from $2.8-12.1 \%$ (Table 1 ). To compare distance values for a second gene in the same set of species, we combined $r b c \mathrm{~L}$ sequences $(n=111)$ from our collections with additional data from GenBank (Appendix 1). Maximum intraspecific divergence for $r b c \mathrm{~L}$ ranged from $0-0.7 \%$, while interspecific variation ranged from $0.9-9.5 \%$ (Table 1 ).
The DNA barcode analysis allowed us to organize our large data set into 15 distinct genetic species groupings (Table 1). Of these 15 genetic groups, ten can be assigned to currently reported species of Laurencia (L. catarinensis, $L$. dendroidea, L. intricata and L. microcladia), Palisada (P. cervicornis, P. corallopsis, P. flagellifera and P. perforata) and Yuzurua (Y. iridescens and $Y$. poiteaui). Two are novel species described herein, Chondrophycus planiparvus Popolizio, C. W.Schneider \& C.E.Lane, sp. nov. and Laurenciella namii Popolizio, C.W.Schneider \& C.E.Lane, sp. nov. The three remaining genetic groups were assigned provisional names pending further study, viz., Laurenciella sp. 1Bda, Palisada sp. 1 USA and Yuzurua sp. 1Bda. 
TABLE 2. - Intraspecific ITS divergence and distance to nearest neighbor for 3 species in the genus Laurencia J.V.Lamouroux

\begin{tabular}{lclc}
\hline Species & $\begin{array}{c}\text { Max intraspecific } \\
\text { divergence (\%) }\end{array}$ & Nearest neighbor & $\begin{array}{l}\text { Distance to nearest } \\
\text { neighbor (\%) }\end{array}$ \\
\hline Laurencia microcladia & 2.0 & Laurencia dendroidea & 29.2 \\
Laurencia catarinensis & 2.1 & Laurencia dendroidea & 32.6 \\
Laurencia dendroidea & 0.6 & Laurencia microcladia & 29.2 \\
\hline
\end{tabular}

We had no genetic groups that were a morphological match to L. caraibica or L. decumbens, species that are also reported for Bermuda.

To further explore the separation between intra- and interspecific sequence variability in a subset of taxa, we selected specimens of Laurencia catarinensis, L. dendroidea and L. microcladia and compared distance values for the ITS region of nuclear rRNA (Appendix 2; Table 2). The 18 ITS sequences generated were unusually long for red algae $(-2700 \mathrm{bp})$ with relatively low levels of variation within species. After removing indels from the alignment $(-1000 \mathrm{bp})$ the maximum intraspecific ITS divergences were lowest among Bermuda $L$. dendroidea ( $0.6 \%$; Table 2), while sequences of $L$. catarinensis from Bermuda had 2.0\% divergence (Table 2). Sequences of L. microcladia from both Bermuda and St. Croix displayed $2.1 \%$ divergence (Table 2 ), just slightly more than $L$. catarinensis despite representing a broader geographical sampling. Comparatively, interspecific ITS distances between the three species ranged from 29.2-32.6\% (Table 2).

For phylogenetic analyses in the complex, the $r b c \mathrm{~L}$ gene was selected given the extent of molecular studies using this gene in the past decade. To place our genetic groups into a phylogenetic context, a representative of each of the previously determined groups was included in a single gene $(r b c \mathrm{~L})$ analysis (1217 bp) along with a diverse representation of taxa assigned to the complex for which data were mined from GenBank (Appendix 1). Phylogenetic associations among genera in the tribe conformed largely to those published by Metti et al. (2015), Rousseau et al. (2017) and Cassano et al. (2019). Our analysis similarly provides robust support for the generic groupings in the complex, except Corynecladia (as in previous studies), which may be partly due to the small number of species in the genus relative to other genera (Fig. 1). Relationships between genera, however, are not supported. Our tree topology depicts the sister relationships of Laurencia-Laurenciella [as in Cassano et al. (2019) and Rousseau et al. (2017)], Osmundea-Chondrophycus [as in Cassano et al. (2019) and Metti et al. (2015)] and Corynecladia-Yuzurua (as in the three publications mentioned previously) (Fig. 1). But none of the analyses, including ours, generated branch values to support these relationships. Phylogenies from the previous studies depict Palisada as sister to the Laurencia-Laurenciella-Yuzurua-Corynecladia clade, with poor support in all except for the Bayesian inference results of Rousseau et al. (2017). Similarly, the Palisada clade resolved as a strongly supported generic grouping in our analysis, but its relationship to other members of the complex remains unresolved.
Finally, the monospecific Ohelopapa groups with Osmundea and Chondrophycus in our phylogeny, a result upheld only by the Bayesian analysis (Fig. 1). Previous phylogenetic studies show different, poorly supported relationships of Ohelopapa with other genera in the complex.

After our barcode gap and phylogenetic analyses, new species in Chondrophycus and Laurenciella are added to the flora of the western Atlantic Ocean. We further discovered several species previously unknown for Bermuda, and these are herein added to the island flora. Due to the lack of a comprehensive description of Laurencia microcladia from the western Atlantic, we provide one here for specimens collected in Bermuda and the U.S. Virgin Islands at the northern end of the West Indies (type locality, "ex India occidentali”; Kützing 1865).

\section{Family RHODOMELACEAE Horaninow Genus Laurencia J.V.Lamouroux}

\section{Laurencia microcladia Kützing}

(Figs 2, 3)

Tabulae phycologicae: 22, pl. 60, figs b, c (1865).

Distribution. - Bermuda, Florida, Central America, Caribbean, Brazil, Mediterranean, Azores, Canary Islands, Cape Verde Islands, North Africa, Arabian Gulf, Singapore, Vietnam, Polynesia, Samoa (Guiry \& Guiry 2021).

\section{DESCRIPTION}

Plants to $6.5 \mathrm{~cm}$ tall, fleshy, green to deep purplish-red, often with distinct purple-red branchlet tips, forming clumps with several associated upright axes; individual axes narrowly pyramidal or sometimes with secondary branches not varying much in length from base to tip of main axes; main axes to $0.5 \mathrm{~mm}$ diam. with discoidal holdfasts; densely irregularly branched in all directions, some branches clustered creating a whorled appearance; branchlets clavate to narrowly turbinate, to $2 \mathrm{~mm}$ long; densely clustered ultimate branches imparting a verrucose appearance. Vegetative axes with 4 pericentral cells; secondary pit connections present; in surface view cortical cells 15-50 $\mu \mathrm{m}$ diam., irregularly rounded to rounded rectangular in upper branch regions, elongate-angular to elongate-ovoid below; corps en cerise present; outer cortical cell projections absent. In transverse section, outer cortical cells appearing subquadrate or campanulate to ovoid, 12-36 $\mu \mathrm{m}$ diam.; medullary cells 45-120 $\mu \mathrm{m}$ diam. Branch tips with deep apical pits, trichoblasts emerging from the pits, dichotomously branched 
to 6 or more orders, and expanding in diam. distally. Tetrasporangia arranged parallel to axis (Saito 1967, p. 71), spherical to slightly ovoid, 60-100 $\mu \mathrm{m}$ diam. (Fig. 3B, C); cystocarps urn-shaped, situated near branchlet tips, 600-820 $\mu \mathrm{m}$ diam. (Fig. 3D), carposporangia obpyriform, 30-60 $\mu \mathrm{m}$ diam. and 80-125 $\mu \mathrm{m}$ long. Spermatia formed in dense fascicles issued from lower portions of trichoblasts, spherical to obovoid, 2-3 $\mu \mathrm{m}$ diam.

Genus Laurenciella V.Cassano, Gil-Rodríguez, Sentíes, Díaz-Larrea, M.C.Oliveira \& M.T.Fujii

\section{Laurenciella namii}

Popolizio, C.W.Schneider \& C.E.Lane, sp. nov.

(Fig. 4)

Holotype. - Craig W. Schneider (CWS)/Christopher E. Lane (CEL)/ Thea R. Popolizio (TRP) 12-11-2 [BDA0597] (Fig. 4B), 18.I.2012, Spanish Point Park, north shore Bermuda I., Bermuda, western At-

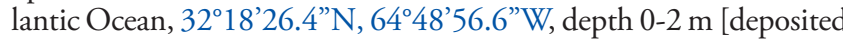
in $\mathrm{MICH}$ ]; isotypes - Bermuda Natural History Museum (BAMZ), Herb. CWS [BDA0598] (Fig. 4A), NY, UNB.

Holotype DNA Barcode. — GenBank OK209887, COI-5P.

PARATYPES. - Bermuda. CWS/CEL/TRP 10-16-12 [BDA0227], 21.VIII.2010, Whalebone Bay, St. George's I., 32²1'51.0”N, 64\%2'43.5"W, depth $1 \mathrm{~m}$; CWS/CEL/TRP 10-33-13 [BDA0502] (see Appendix 1); CWS/CEL/TRP 10-33-15 [BDA0504], 25.VIII.2010, Spanish Point Park, loc. cit., depth 2 m; CWS/CEL/TRP 12-8-1 [BDA0544], 17.VI.2012, Brackish Pond Flats, north shore Bermuda I., 32 $21^{\circ} 07.0^{\prime \prime N}$, 64² $48^{\prime} 02.5^{\prime \prime W}$, depth 3-4 m; TRP/CWS 12-143-4 [BDA1591], 25.X.2012, Trunk I., Harrington Sound, 32 $2^{\circ} 9^{\prime} 58.7^{\prime \prime} \mathrm{N}$, 6443'33.9"W, depth 1-2 m; CWS/TRP 13-20-4 [BDA1871], 18.IX.2013, Whalebone Bay, loc. cit., depth $1 \mathrm{~m}$. Florida. CWS/ CEL/TRP/D.C. McDevit (DCM) 13-9-5 [KW109] (see Appendix 1); CWS/CEL/TRP/DCM 13-9-17 [KW125], 29.V.2013, Key West, White St. Pier, 2432'45.4”N, 8147'00.0"W, depth $2 \mathrm{~m}$; CWS/ CEL/TRP/DCM 13-9-25 [KW133], White St. Pier, loc. cit., depth $2 \mathrm{~m}$; CWS/CEL/TRP/DCM 13-14-7 [KW219], 31.V.2013, Cudjoe, Summerland Bridge, $24^{\circ} 39^{\prime} 39.0^{\prime \prime} \mathrm{N}, 81^{\circ} 26^{\prime} 10.9^{\prime \prime} \mathrm{W}$, depth 1-3 m.

EPONOMY. - An honorific name for Professor Ki Wan Nam of Pukyong National University, Korea, who has played a significant role in the taxonomic diversification of the Laurencia complex using both morphological and phylogenetic data.

Distribution. - Bermuda and Florida, United States.

SEASONALiTY. - Collected throughout the year in Bermuda.

\section{DESCRIPTION}

Plants to $15 \mathrm{~cm}$ tall with main axes yellow-orange and deep red branchlets (Fig. 4A), fleshy; main axes lax, slender, to $1 \mathrm{~mm}$ diam., suboppositely to alternately spiraled branching and arising from discoidal holdfasts. Mature axes in lower portions, elongated and lacking branchlets, appearing denuded (Fig. 4A); upper portions demonstrating profuse alternate to irregular branching (Fig. 4C); ultimate branchlets cylindrical to clavate, to $2 \mathrm{~mm}$ long and $140-350 \mu \mathrm{m}$ in diam . Vegetative axes with 4 pericentral cells; secondary pit connections present in cortical cells; cortical cells in surface view 20-45 $\mu \mathrm{m}$ diam., irregularly rounded-polygonal to ovoid, becoming more elongated in lower portions of branches, outer cortical cells often appearing obpyriform at branch apices; corps en cerise present in living plants, one per outer cortical cell; outer cortical cells acutely projecting, the surface appearing crenate in longitudinal section (Fig. 4D, F). In transverse section, two layers of pigmented cortical cells with three inner layers of colorless irregularly globose medullary cells 30-115 $\mu \mathrm{m}$ diam., decreasing in size radially toward the cortex (Fig. 4E). In section, outer cortical cells rounded-rectangular to ovoid or campanulate, 25-40 $\mu \mathrm{m}$ diam. and 20-35 $\mu \mathrm{m}$ long. Deep apical pits at branch apices bearing dense trichoblast systems to $220 \mu \mathrm{m}$ long with 3-4 orders of subdichotomous branching (Fig. 4F, G). Reproductive structures not found. Distinct from other species of Laurenciella by its COI-5P and $r b c \mathrm{~L}$ molecular sequences.

\section{Genus Chondrophycus \\ (J.Tokida \& Y.Saito) Garbary \& J.T.Harper}

\section{Chondrophycus planiparvus}

Popolizio, C.W.Schneider \& C.E.Lane, sp. nov. (Fig. 5)

Holotype. - T.R. Popolizio/C. W. Schneider 12-40-13 (BDA0934), 13.III.2012, Gurnet Rock, mouth of Castle Harbour, Bermuda, western Atlantic Ocean, 32²0’22.7”N, 6439'44.8”W, depth 13 $\mathrm{m}$ [deposited in UNB]; iso-, MICH [TRP 12-40-12 (BDA0933)].

Holotype DNA Barcode. - GenBank OK209884, COI-5P; OK209859, $r b c \mathrm{~L}$.

PARATYPES. - Bermuda. CWS/CEL 09-30-9, 19.III.2009, Gurnet Rock, loc. cit., 32'20'20.2”N, 64³9'32.1”W, depth 16-17 m; TRP/ CWS 12-148-6 [BDA1625], 5.XI.2012, wreck of the Pelinaion, north shore Bermuda I., 32 $21^{\prime} 20.9^{\prime} \mathrm{N}, 64^{\circ} 38^{\prime} 36.9^{\prime}$ 'W, depth $18 \mathrm{~m}$; TRP/CWS 12-160-8 [BDA1741], 1.XII.2012, wreck of the Hermes,

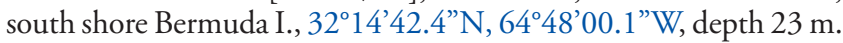

ETYMOLOGY. - From the Latin, describing the typical habit of this flattened ('planus') and relatively small ('parvus') species.

Distribution. - Endemic to Bermuda as presently known.

SEAsonality. - Collected from November to March in Bermuda.

\section{DESCRIPTION}

Plants to $2 \mathrm{~cm}$ high, distinctly compressed, rosy-red, cartilaginous (Fig. 5A-D); main axes to $2 \mathrm{~mm}$ diam. with one or more arising from discoidal holdfasts; branching irregular to opposite or alternate, with branch apices sometimes appearing trifurcated (Fig. 5B, D); branchlets to $2 \mathrm{~mm}$ in diam. Vegetative axes with 2 pericentral cells; cortical cells arranged longitudinally in surface view (Fig. 5E, H), secondary pit connections abundant (Fig. 5G, H). In transverse section, non-palisade outer cortical cells, obtriangulate to obovate, with constrictions at the base (Fig. 5G), 12-35 $\mu \mathrm{m}$ diam. and 9-27 $\mu \mathrm{m}$ long, some acute projections present at branch apices in surface view; outer cortical cells ovoid in upper branch regions, irregularly angular and elongated below, 9-55 $\mu \mathrm{m}$ diam. and 20-100 $\mu \mathrm{m}$ long (Fig. 5H); lenticular thickenings 
A

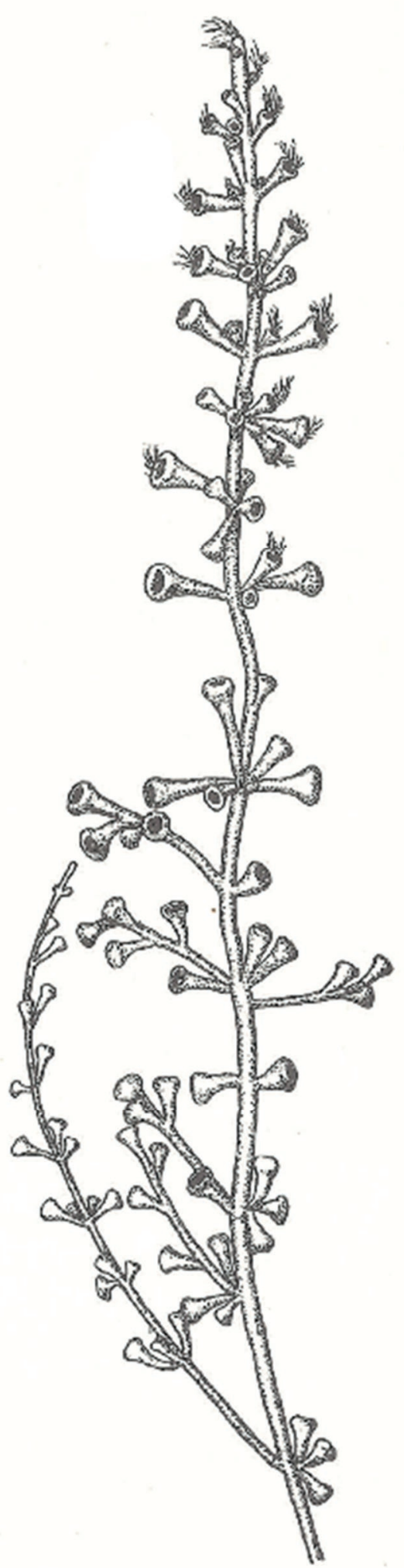

B

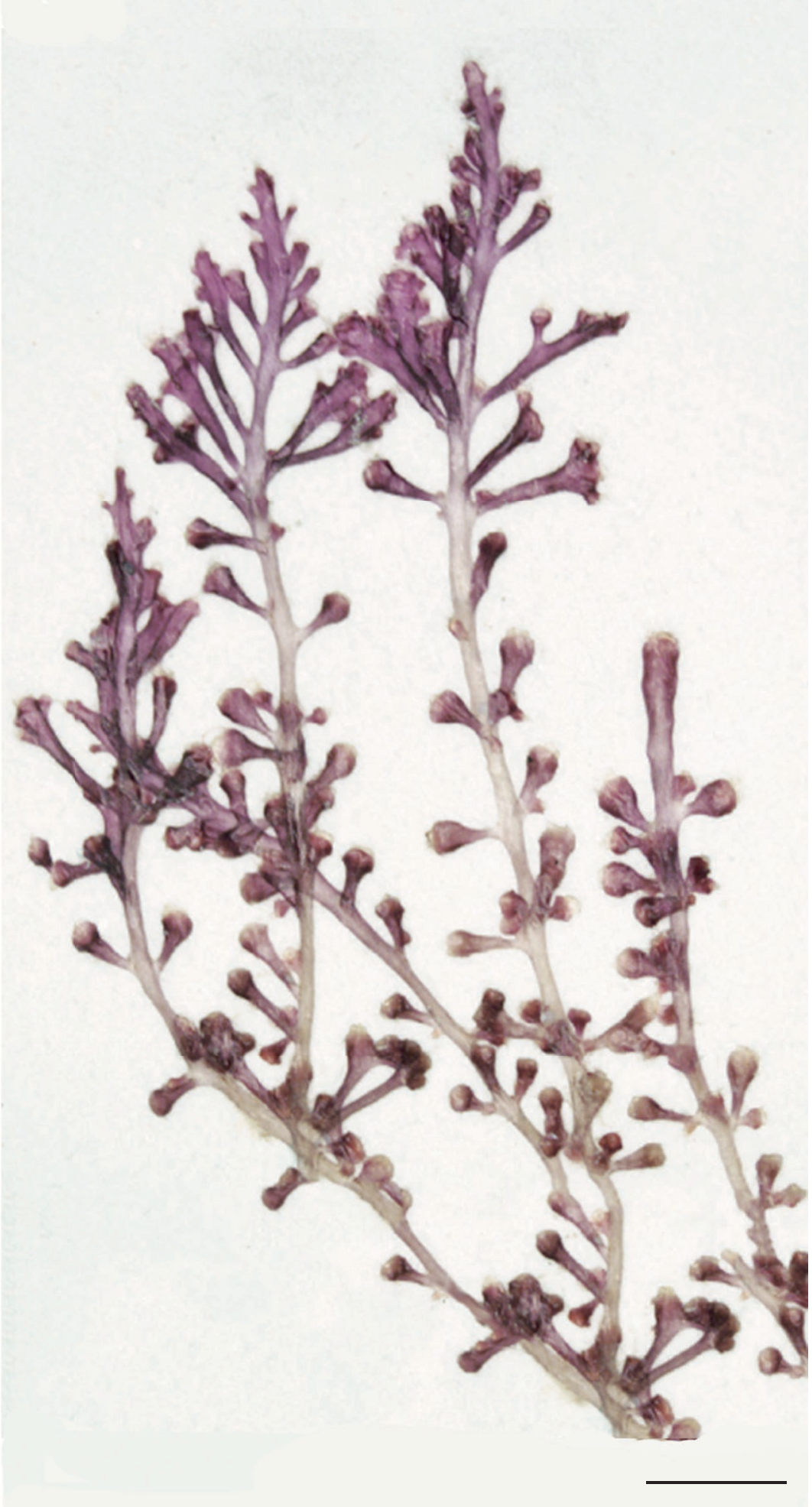

FIG. 2. - Laurencia microcladia Kützing: A, illustration of L. microcladia from Børgesen (1915, as L. obtusa var. gelatinosa (J.V.Lamouroux) J.Agardh) from the US Virgin Islands; B, Sequenced specimen of L. microcladia collected in St. Croix, USVI, Caribbean Antilles [CEL/TRP/EDS 13-26-2/STX079]. Scale bar: 2 mm.

absent in the walls of medullary cells. Extensive trichoblasts emerging from shallow apical pits (Fig. 5F), dichotomously branched, to $600 \mu \mathrm{m}$ long. Tetrasporangia forming at api- ces, slightly ovoid, arranged at right angles to the axis (Saito 1967: 71), 43-68 $\mu \mathrm{m}$ diam. and 48-96 $\mu \mathrm{m}$ long (Fig. 5I). Gametangia not found. 

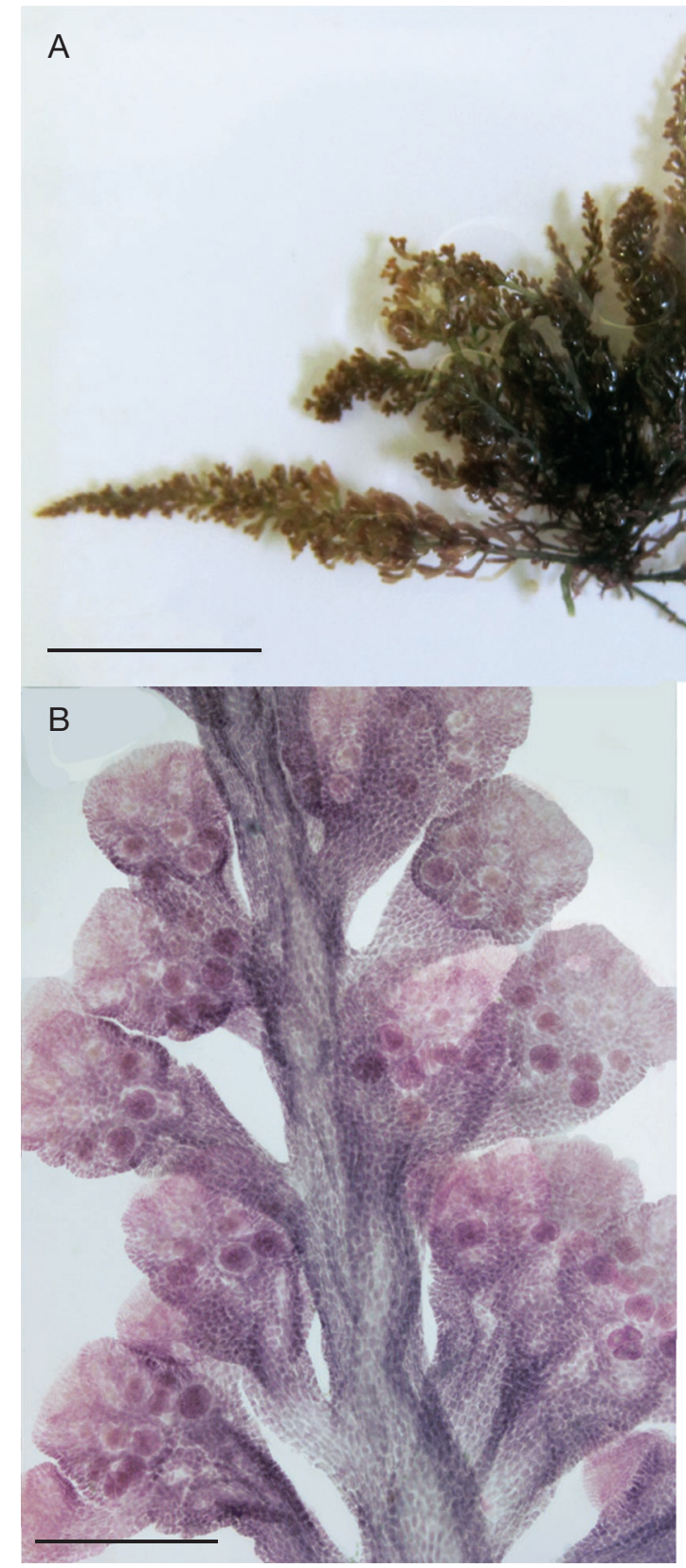

C

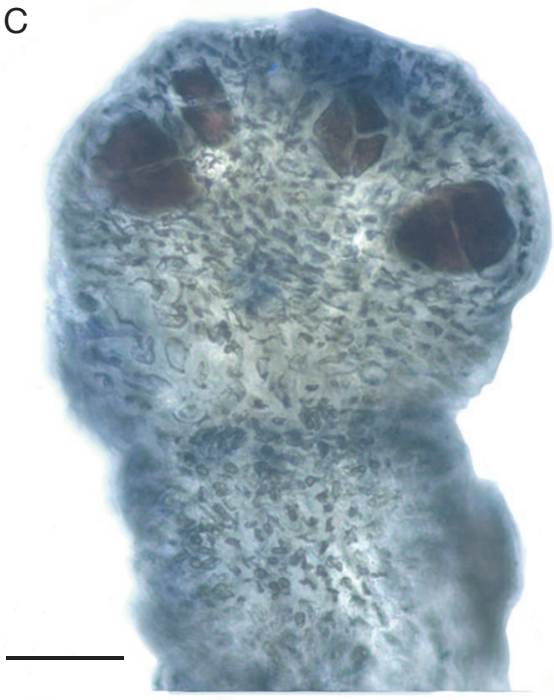

D

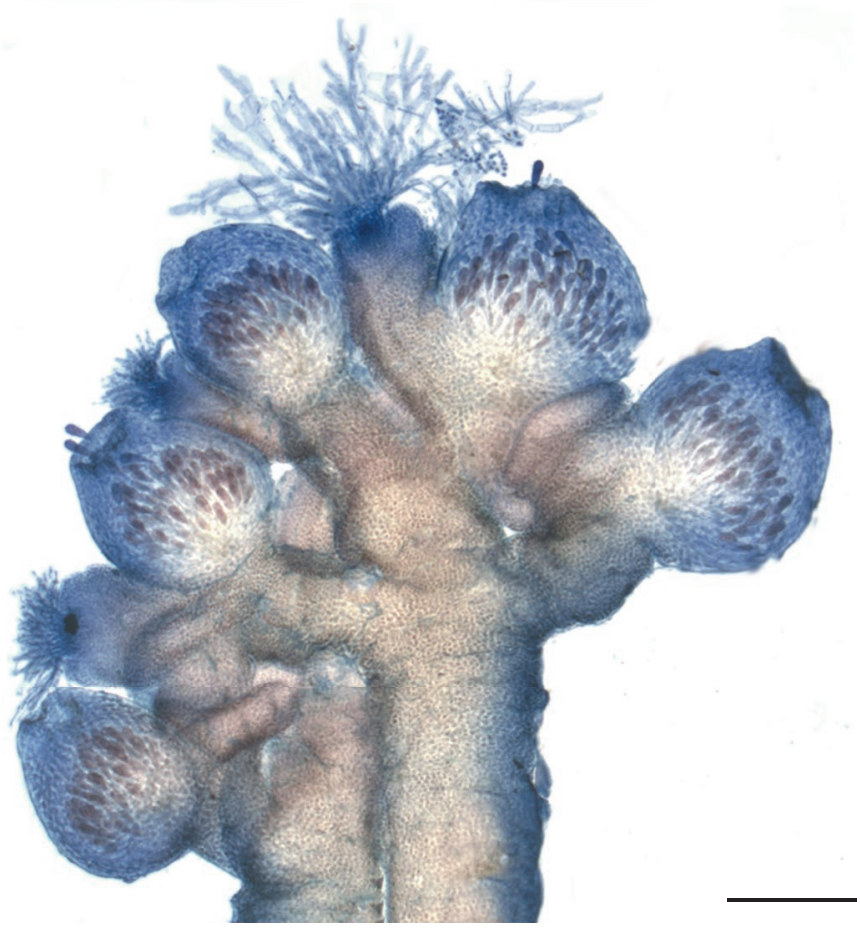

FIG. 3. - Laurencia microcladia Kützing: A, habit with clustered characteristic narrowly pyramidal axes [TRP 12-30-11/BDA0818]. B, whole mount of tetrasporic specimen, displaying irregular branching in all planes and parallel arrangement of tetrasporangia [CWS/CEL 03-21-1]; C, longitudinal section of branch tip showing parallel arrangement of tetrasporangia [TRP 12-172-3]; D, whole mount of female specimen illustrating clustered, urn-shaped cystocarps and obpyriform carposporangia [CWS/CEL 03-21-1]. Scale bars: A, $2 \mathrm{~cm} ; \mathrm{B}, \mathrm{C}, 250 \mu \mathrm{m} ; \mathrm{D}, 500 \mu \mathrm{m}$.

\section{DISCUSSION}

THE GENUS LAURENCIA IN BERMUDA

COI-5P and $r b c \mathrm{~L}$ sequence data support the recognition of two species for collections long called Laurencia obtusa in Bermuda, both of which are distantly related to true L. obtusa from Europe. These species represent examples of western Atlantic entities with a misassigned European binomial placed upon them by phycologists of the $19^{\text {th }}$ and early 20th centuries (see Popolizio et al. 2013). The $r b c \mathrm{~L}$ barcode gap analysis presents support for the conspecific- ity of Bermuda specimens with Laurencia dendroidea and L. catarinensis from Brazil (Cassano et al. 2012a; MachínSánchez et al. 2012). Intraspecific divergences in $r b c \mathrm{~L}$ for the two are $0.5 \%$ and $0.3 \%$, respectively, compared with interspecific divergences of $5.5 \%$ and $3.7 \%$ (Table 1). These species herein represent new reports for Bermuda. Our collections of these two species had previously been assigned to L. obtusa, but our molecular data suggest L. obtusa is not found in Bermuda and likewise may not be present in the tropical western Atlantic. These data also show that both species are present in the Florida Keys and St. Croix 


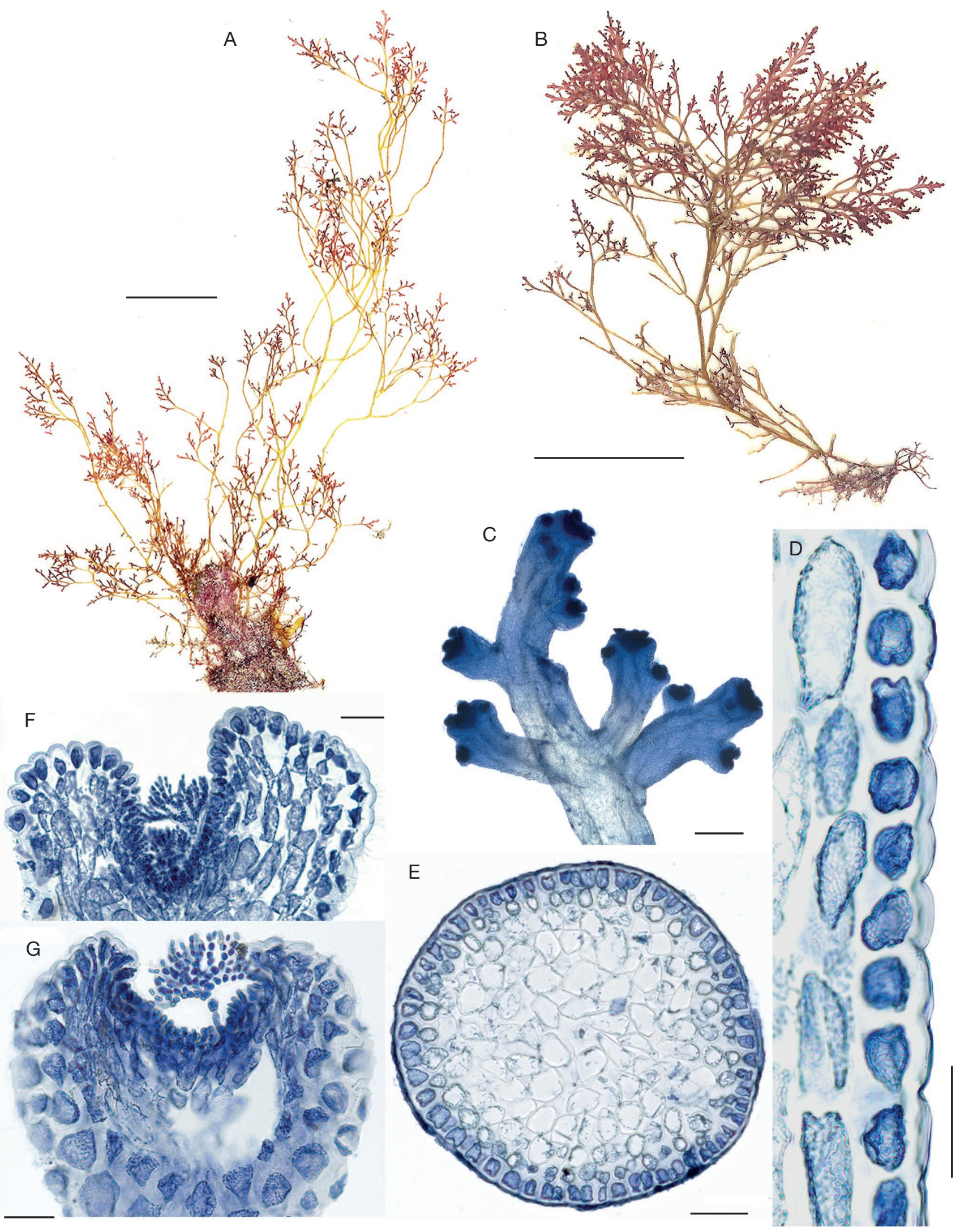

FIG. 4. - Laurenciella namii Popolizio, C.W.Schneider \& C.E.Lane sp. nov. A, isotype specimen [CWS/CEL/TRP 12-11-2/BDA0598]; B, holotype specimen [CWS/ CEL/TRP 12-11-2/BDA0597]; C axial tip displaying irregular branching [CWS/CEL/TRP/DCM 13-9-17/KW125]: D, Longitudinal section of branch with outer cortical cells demonstrating a crenate margin [CWS/CEL/TRP/DCM 13-9-17/KW125]; E, transverse section of axis showing two outer layers of corticated pigmented cells and four inner layers of colorless, irregularly globose medullary cell layers [CWS/CEL/TRP/DCM 13-9-17/KW125]; F, longitudinal section of axial tip illustrating apical pit, trichoblasts and crenate outer margins [CWS/CEL/TRP/DCM 13-9-5/KW109]; G, longitudinal section of axial tip; orientation shows depth of apical pit and developing trichoblasts [CWS/CEL/TRP/DCM 13-9-17/KW125]. Scale bars: A, 2 cm; B, 1 cm; C, $500 \mu \mathrm{m} ; \mathrm{D}, \mathrm{F}, \mathrm{G}, 50 \mu \mathrm{m} ; \mathrm{E}, 100 \mu \mathrm{m}$. 
TABLE 3. - Morphological character comparisons for treatments of Laurencia microcladia Kützing, L. caduciramulosa Masuda \& S.Kawaguchi, L. laurahuertana Mateo-Cid, Mendoza-Gonzalez, Sentíes \& Díaz-Larrea and L. venusta Yamada.

\begin{tabular}{|c|c|c|c|c|c|c|c|}
\hline & $\begin{array}{l}\text { Laurencia } \\
\text { microcladia }\end{array}$ & $\begin{array}{l}\text { Laurencia } \\
\quad \text { microcladia }\end{array}$ & $\begin{array}{l}\text { Laurencia } \\
\text { caduciramulosa }\end{array}$ & $\begin{array}{l}\text { Laurencia } \\
\text { caduciramulosa }\end{array}$ & $\begin{array}{l}\text { Laurencia } \\
\text { laurahuertana }\end{array}$ & $\begin{array}{c}\text { Laurencia } \\
\text { venusta }\end{array}$ & Laurencia venusta \\
\hline $\begin{array}{l}\text { Location of } \\
\text { specimens } \\
\text { used for data }\end{array}$ & $\begin{array}{l}\text { West Indies } \\
\text { (type locality) }\end{array}$ & Bermuda & $\begin{array}{l}\text { Vietnam } \\
\text { (type locality) }\end{array}$ & $\begin{array}{l}\text { Florida, United } \\
\text { States }\end{array}$ & $\begin{array}{l}\text { Caribbean } \\
\text { Mexico } \\
\text { (type locality) }\end{array}$ & \multicolumn{2}{|c|}{$\begin{array}{l}\text { Caribbean Mexico Korea and Japan } \\
\text { (type locality) }\end{array}$} \\
\hline Thallus color & $\begin{array}{l}\text { Gray-green to } \\
\text { purple-green }\end{array}$ & $\begin{array}{l}\text { Green to deep } \\
\text { purple-red, often } \\
\text { with distinct } \\
\text { purple-red } \\
\text { branchlet tips }\end{array}$ & Purple-red & Greenish-brown & Pale green & Pale green & $\begin{array}{l}\text { Brown, greenish } \\
\text { or purple red or } \\
\text { brown with pink } \\
\text { branch tips }\end{array}$ \\
\hline $\begin{array}{l}\text { Length of upright } \\
\text { axes }(\mathrm{cm})\end{array}$ & tto 10 & to 6.5 & $2-5$ & to 1 & to 0.7 & to 7 & to 10 \\
\hline $\begin{array}{l}\text { Branching } \\
\text { pattern }\end{array}$ & $\begin{array}{l}\text { Alternately to } \\
\text { irregularly } \\
\text { branched, } \\
\text { dense distally }\end{array}$ & $\begin{array}{l}\text { Alternately to } \\
\text { irregularly } \\
\text { branched, } \\
\text { dense distally; } \\
\text { some branches } \\
\text { clustered, } \\
\text { appearing } \\
\text { whorled }\end{array}$ & $\begin{array}{l}\text { Irregularly } \\
\text { alternate and } \\
\text { spirally arranged }\end{array}$ & $\begin{array}{l}\text { Irregularly } \\
\text { alternate } \\
\text { and spirally } \\
\text { arranged, } \\
\text { usually with } \\
2-3 \text { orders of } \\
\text { branches }\end{array}$ & $\begin{array}{l}\text { Sparse, } \\
\text { dichotomous } \\
\text { below, } \\
\text { irregularly } \\
\text { alternate above }\end{array}$ & $\begin{array}{l}\text { Sparse, } \\
\text { verticillate, 2-4 } \\
\text { branches per } \\
\text { verticile, less } \\
\text { commonly } \\
\text { opposite, } \\
\text { alternate or } \\
\text { irregular }\end{array}$ & $\begin{array}{l}\text { Irregularly alternate, } \\
\text { subopposite or } \\
\text { subverticillate; } \\
\text { occasionally } \\
\text { curved branches } \\
\text { with secund } \\
\text { ultimate } \\
\text { branchlets }\end{array}$ \\
\hline $\begin{array}{l}\text { Outer cortex cell } \\
\text { diam. }(\mu \mathrm{m}) \text { on } \\
\text { main axes }\end{array}$ & 130-60 & $15-50$ & $\begin{array}{l}\text { 10-30 distally, } \\
\text { 20-36 proximally }\end{array}$ & $23-45$ & Not reported & $14-52$ & $33-58$ \\
\hline $\begin{array}{l}\text { Outer cortex } \\
\text { cross- } \\
\text { sectional cell } \\
\text { projection }\end{array}$ & Not reported & Absent & $\begin{array}{l}\text { Slightly near } \\
\text { branch apices }\end{array}$ & Present & $\begin{array}{l}\text { Present } \\
\text { (undulate) }\end{array}$ & Absent & Absent or slight \\
\hline $\begin{array}{l}\text { Tetrasporangial } \\
\text { arrangement }\end{array}$ & Not reported & Parallel & Not reported & Not reported & Not reported & Parallel & Parallel \\
\hline Tetrasporangia & $\begin{array}{l}\text { Spherical } \\
\text { to ovoid; } \\
65-100 \mu \mathrm{m} \\
\text { diam. }\end{array}$ & $\begin{array}{l}\text { Spherical to } \\
\text { slightly ovoid; } \\
60-100 \mu \mathrm{m} \text { diam. }\end{array}$ & Not reported & Not reported & 60-65 $\mu \mathrm{m}$ diam. & 40-80 $\mu \mathrm{m}$ diam. & 75-86 $\mu \mathrm{m}$ diam. \\
\hline $\begin{array}{l}\text { Cystocarp } \\
\text { shape }\end{array}$ & $\begin{array}{l}\text { Spherical to urn- } \\
\text { shaped; near } \\
\text { branchlet tips }\end{array}$ & $\begin{array}{l}\text { Urn-shaped, } \\
\text { situated near } \\
\text { branchlet tips }\end{array}$ & Not reported & Not reported & Urn-shaped & $\begin{array}{l}\text { Prominent; } \\
\text { laterally } \\
\text { positioned } \\
\text { to bearing } \\
\text { branchlet; urn- } \\
\text { shaped to } \\
\text { conical }\end{array}$ & $\begin{array}{l}\text { Urn-shaped } \\
\text { to conical or } \\
\text { ovoid without } \\
\text { a protuberant } \\
\text { ostiole }\end{array}$ \\
\hline $\begin{array}{l}\text { Cystocarp diam. } \\
(\mu \mathrm{m})\end{array}$ & $500-700$ & $600-820$ & Not reported & Not reported & $450-500$ & $400-600$ & $600-870$ \\
\hline Carposporangia & Not reported & $\begin{array}{l}\text { Obpyriform, } \\
\text { 80-125 } \mu \mathrm{m} \text { long, } \\
30-60 \mu \mathrm{m} \text { diam. }\end{array}$ & Not reported & Not reported & $\begin{array}{l}\text { Pyriform; } \\
\text { 90-100 } \mu \mathrm{m} \\
\text { long, 22-25 } \mu \mathrm{m} \\
\text { diam. }\end{array}$ & $\begin{array}{l}100-150 \mu \mathrm{m} \text { long, } \\
30-50 \mu \mathrm{m} \text { diam. }\end{array}$ & Not reported \\
\hline Spermatangia & Not reported & $\begin{array}{l}\text { Spherical to ovoid; } \\
4.5-10 \mu \mathrm{m} \text { diam.; } \\
\text { sterile apical } \\
\text { cells present }\end{array}$ & Not reported & Not reported & $\begin{array}{l}\text { Ovoid, } 11-13 \mu \mathrm{m} \\
\text { long, } 3-4 \mu \mathrm{m} \\
\text { diam.; sterile } \\
\text { apical cells } \\
\text { absent }\end{array}$ & $\begin{array}{l}\text { Ovoid; } 6-11 \mu \mathrm{m} \\
\text { long, } 4-7 \mu \mathrm{m} \\
\text { diam.; sterile } \\
\text { apical cells } \\
\text { present }\end{array}$ & $\begin{array}{l}\text { Ovoid; } 10-12 \mu \mathrm{m}, \\
5-7 \mu \mathrm{m} \text { diam.; } \\
\text { sterile apical cells } \\
\text { present }\end{array}$ \\
\hline $\begin{array}{l}\text { References for } \\
\text { data }\end{array}$ & $\begin{array}{l}\text { Taylor 1960; } \\
\text { Howe 1918; } \\
\text { Littler \& Littler } \\
\text { 2000; Dawes \& } \\
\text { Mathieson } 2008\end{array}$ & $\begin{array}{l}\text { Present study } \\
8\end{array}$ & $\begin{array}{l}\text { Masuda et al. } \\
1997\end{array}$ & $\begin{array}{l}\text { Collado-Vides } \\
\text { et al. } 2014\end{array}$ & $\begin{array}{l}\text { Mateo-Cid et al. } \\
2014\end{array}$ & Sentíes et al. 2001 & $\begin{array}{l}1 \text { Yamada 1931; Saito } \\
\text { 1967; Nam et al. } \\
2000\end{array}$ \\
\hline
\end{tabular}

in the US Virgin Islands. Notably, specimens we have identified as having "red" habits in our collections group only within the $L$. dendroidea clade, along with green and purple-green morphs of this species. All specimens that were noted as 'green with pink tips' in our field notes fall within the $L$. catarinensis clade. It is likely that Howe (1918) was examining collections of $L$. catarinensis when describing 'L. obtusa' from the islands as "subglobose tufts" that are "often greenish with red tips," features that appear to char- acterize the habit of this species based on our observations and genetic sequences.

The presence of Laurencia intricata in Bermuda also has been verified with molecular data. Sequence data show that this species, first reported for the islands by Howe (1918), is conspecific with specimens from the Caribbean Antilles, the type locality of this species. Intraspecific divergence values are $0.1 \%$ in COI-5P and $0.3 \%$ in $r b c \mathrm{~L}$ (Table 1 ). We have discovered a specimen of $L$. intricata among Hervey's archived 
A

$\mathrm{B}$

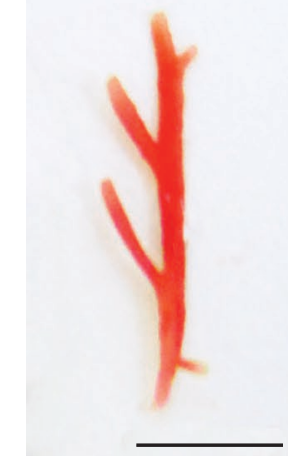

E MO

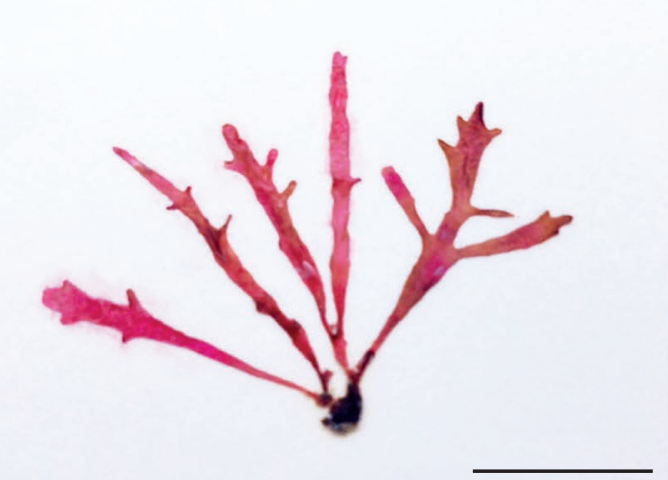

C

D
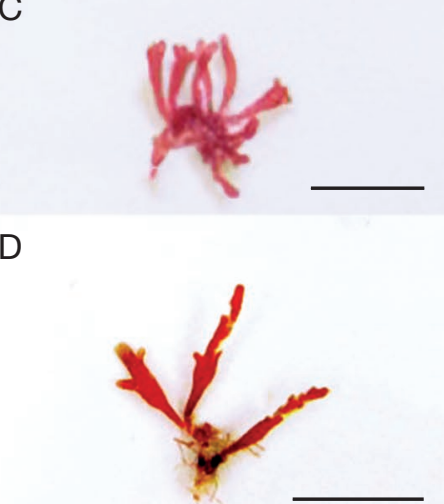

Pin

in - 160 a d पfon ave at 401 G 3. aromes f. $x$ s 5 ?

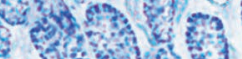
(4)

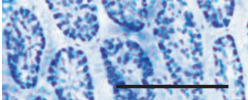
$5243 \frac{2 n^{2}}{2 n^{2}}$
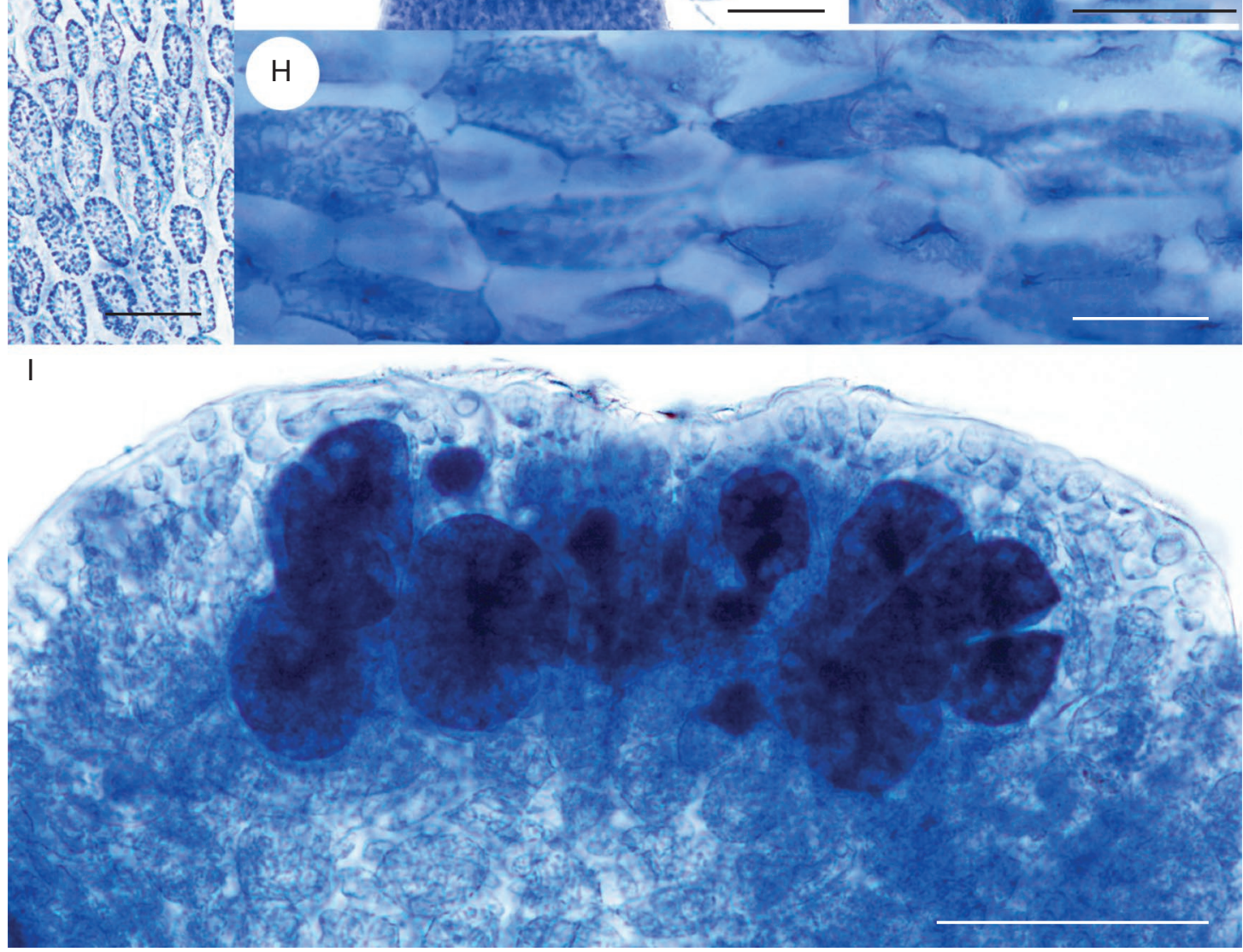

FIG. 5. - Chondrophycus planiparvus Popolizio, C.W.Schneider \& C.E.Lane sp. nov. A, holotype specimen [TRP 12-40-13/BDA0934]; B, specimen with two branched axes arising from a common holdfast [CWS/CEL 9-30-9]; C, habit of small live specimen, [TRP 12-160-8/BDA1741]; D, habit of small pressed specimen [TRP 12-148-6/BDA1625]; $\mathbf{E}$, axial view of cortex showing irregularly angular to ovoid surface cells [TRP 12-148-6/BDA1626]; $\mathbf{F}$, branch apex with new and mature trichoblasts emerging from an apical pit [CWS/CEL 9-30-9]; G, secondary pit connections (arrowheads) between adjacent outer cortical cells in transverse section [TRP 12-40-13/BDA0934]; H, whole mount surface view of outer cortex in lower portions of axes showing irregularly angled surface cells and secondary pit connections [CWS/CEL 09-30-9]; I, longitudinal section of

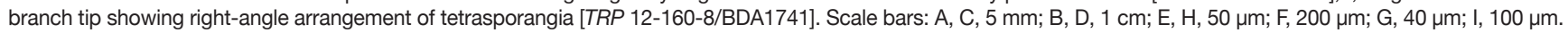


material collected at Heron Bay, Bermuda (P.B.-A. no. 1937, as Laurencia tuberculosa J.Agardh; Collins et al. 1913). The P.B.-A. exsiccata has specimens of this number representing at least two heterotypic members of the 'Laurencia-complex'. Early workers moved all P.B.-A. no. 1937 material to Laurencia poiteaui, yet one representative specimen $(\mathrm{MICH}$ 6605) is L. intricata, while the other (MICH 622078) is likely Yuzurua poiteani.

The first account of Laurencia microcladia in the literature is by Kützing (1865: 22, pl. 60, figs b, c) who illustrated material from the West Indies in a way that distinctly highlights the virgate habit of this species. Børgesen (1915) later reported L. obtusa var. gelatinosa (Desfontaines) J.Agardh from the region, a name that has since been placed in synonymy with L. microcladia. Collins \& Hervey (1917) described their collections (reported as L. obtusa var. gelatinosa) as a "low and slender form of exposed rocky shores" archetypal of this species. Howe (1918) also notes that intertidal collections of $L$. microcladia from Bermuda are included as "P.B. $-A$. no. 1888 , as L. obtusa var. gelatinosa" (Collins et al. 1912). In his account, Børgesen (1915) highlights the pyramidal shape of the thallus, nature of verticillate branching with swollen, clavate branchlets (Fig. 2A), and the tendency of this species to exist in particularly exposed habitats. His illustration of the U.S. Virgin Islands specimen bears a remarkable resemblance to our L. microcladia from St. Croix, USVI (Fig. 2B). Taylor (1960) provided the first detailed description of L. microcladia for the western Atlantic which fits observations of our specimens from both Bermuda and St. Croix with morphological overlap in all characters for which data have been reported by various authors since (Table 3 ).

Intraspecific divergence values for specimens assigned to Laurencia microcladia are $0.5 \%$ and $0.4 \%$ for COI-5P and $r b c \mathrm{~L}$, respectively, compared with interspecific divergences of $4.6 \%$ and $1.2 \%$. To further support the conspecificity of L. microcladia specimens we collected at the Caribbean type locality with those from Bermuda, we compared ITS intraspecific sequence divergences for several isolates of $L$. microcladia and two additional species (L. catarinensis and $L$. dendroidea) within Laurencia (Appendix 2), as well as distances to nearest neighbor, as reported in the results section above. We found that intraspecific divergence for L. microcladia was a maximum of $2.1 \%$ while the distance to the nearest neighbor species (L. dendroidea) was 29.2\% (Table 2). Based on these values, as well as the analyses described above, we consider that specimens of $L$. microcladia from Bermuda and St. Croix represent a single taxon.

Surprisingly, Laurencia microcladia, a fairly common intertidal species in Bermuda and the Caribbean Antilles (Taylor 1960), has not been included in any molecular studies of the Laurencia complex that have been conducted over the past several years in Mexico or Brazil (e.g., Martin-Lescanne et al. 2010; Fujii et al. 2011; Sentíes et al. 2011, 2019; Cassano et al. 2012a, 2012b, 2019; Machín-Sánchez et al. 2012; Machín-Sánchez et al. 2018; Mateo-Cid et al. 2014). Fujii \& Sentíes (2005) document previous reports of L. microcladia in Brazil (Oliveira Filho 1977; Cordeiro-Marino 1978;
Pinheiro-Joventino et al. 1998; Figueiredo et al. 2004) but do not include the species in their detailed monograph of the complex in Brazil. The authors do, however, include L. venusta Yamada, a species from Japan reported for the first time in the Atlantic by Sentíes et al. (2001) from the Mexican Caribbean, and described to be "entirely in concordance" with Japanese material examined by Saito (1964) and without "significant differences" from Yamada's (1931) type specimen. The authors briefly mention the similarities between Mexican L. venusta and L. chondrioides Børgesen from the West Indies but do not discuss similarities with other western Atlantic species of the genus, including L. microcladia, with which it shares a significant number of morphological characteristics (Table 3). The features of L. microcladia from the western Atlantic, including Bermuda, conform to all of the vegetative and reproductive characters described for $L$. venusta from this region, except that in $L$. venusta, sparse verticillate branching is emphasized. Laurencia microcladia is densely branched and possesses verrucose branchlets that are clustered in a manner that creates a whorled appearance, however, branching overall is more irregular than verticillate (Fig. 3A). Additionally, though the observed diameters for tetrasporangia and cystocarps in the two species overlap, the upper limits of these tend to be larger in L. microcladia than in L. venusta, especially compared with Caribbean specimens of the latter species (Table 3).

Our $r b c \mathrm{~L}$ sequences from specimens of Laurencia microcladia are almost identical to those from a specimen identified as L. venusta from Caribbean Mexico, with only $0.2-0.4 \%$ divergences between the sequences. Specifically, two of 1217 base pairs were different between our St. Croix specimen and the GenBank data for $L$. venusta from Caribbean Mexico; five differences were present between both Caribbean specimens and Bermuda specimens. It is likely that the entities shown in the previous analyses are genetic variants of $L$. microcladia, a name that precedes $L$. venusta by more than half a century. Alternatively, the two may represent cryptic species from different ocean basins, but given the near genetic equivalence of these specimens as clearly demonstrated by our data, we think that this is doubtful. While molecular sequence data of L. venusta from Australia are clearly distinct in this analysis, data from $L$. venusta from the type locality in Japan will be required to decisively clarify this matter.

Our specimens of Laurencia microcladia are also closely related in $r b c \mathrm{~L}$ sequence analysis to L. laurahuertana MateoCid, Mendoza-Gonzalez, Sentíes \& Díaz-Larrea (Mateo-Cid et al. 2014) with $0.5 \%$ sequence variation. As such, the vegetative and reproductive characteristics observed in this species are presented for comparative purposes in Table 3. Laurencia laurahuertana is distinguished from L. microcladia by its unusually diminutive size and exclusively being an epiphyte of seagrasses. Laurencia microcladia specimens collected in Bermuda are strictly intertidal and epilithic with the exception of two shallow subtidal specimens from Spanish Point and Shelly Bay, but tidal exposure at these locations is possible during the lunar cycle. The presence of fertile specimens of L. laurahuertana suggests that these are not simply immature 
stages in the life cycle of a larger species. Other notable differences in L. laurahuertana include cortical cell projections (absent in L. microcladia), markedly smaller tetraporangial, cystocarpic and carposporangial diameters, and the absence of a sterile apical cell in spermatangial stichidia. Genetic variation between and L. laurahuertana and Bermuda L. microcladia is well within the intraspecific limits defined for the genus; however, it should be noted that the $r b c \mathrm{~L}$ sequence of $L$. laurahuertana available in GenBank is shorter in sequence length (826 bp) than those that we produced (1217 bp). Thus, longer $r b c \mathrm{~L}$ sequences from $L$. laurahuertana are needed to know definitively whether it is synonymous with $L$. microcladia.

Another $r b c \mathrm{~L}$ sequence, from a specimen identified as L. caduciramulosa from Key Biscayne, Florida, is closely aligned to our $L$. microcladia sequences, with $0.5 \%$ intraspecific divergence. But when compared with sequences from specimens identified as L. caduciramulosa from Spain and Brazil, the Florida species differs by $1.2 \%$. Since molecular data group this species more closely with our L. microcladia than $L$. caduciramulosa, we compared morphology for the two, along with those of L. caduciramulosa from Vietnam, the type locality (Table 3), but morphological features largely overlap for the two species where data are available to assess. Reproductive characters are not reported for $L$. caduciramulosa from either location, making diagnosis based on morphology impracticable. For now, the molecular data suggest that the species from Florida is indeed L. microcladia, and not L. caduciramulosa from the Pacific.

\section{The genus PaLisada In Bermuda}

The molecular sequence data we have produced verify that Palisada perforata in Bermuda is conspecific with specimens from the type locality (Canary Islands, Spain) with $0.6 \%$ and $0.2 \%$ intraspecific divergence in COI-5P and $r b c \mathrm{~L}$, respectively. This species is the most common member of the genus Palisada in our Laurencia complex collections, and is predominantly intertidal with a few exceptions from shallow subtidal sites in the Florida Keys and a single subtidal collection from a shallow subtidal site (3-4 m) off Bermuda's north shore. Another species in the genus, $P$. flagellifera, with a type locality in the Indian Ocean, is reported as pantropical with amphi-Atlantic reports from Cuba (Areces et al. 2003), Brazil (Fujii et al. 2006) and the Canary Islands (Gil-Rodriguez et al. 2010). Our COI-5P barcode investigation indicated a group within the Palisada clade that was distinct from reported Bermuda species $-r b c \mathrm{~L}$ sequences from these collections align with P. flagellifera sequences from Brazil and the Canary Islands (intraspecific divergence $=0.2 \%$ ). Comparative molecular data are not available for specimens from the Indian Ocean type locality. The present report represents the first record of P. flagellifera in Bermuda.

Accounts of Palisada corallopsis (as Laurencia corallopsis) (Montagne) M.Howe in Bermuda (type locality = Cuba) have appeared in the literature since the early $20^{\text {th }}$ century [Howe 1918, as L. corallopsis; Frederick 1963, as L. corallopsis; Schneider 2003, as Chondrophycus corallopsis (Montagne) K.W.Nam]. Harvey's (1853) L. cervicornis Harvey (type locality
$=$ Key West) had long been merged with P. corallopsis (Howe 1918) and Collins et al. (1917, P.B.-A. no. 2187) and Collins $\&$ Hervey (1917) reported their collections from Bermuda as L. cervicornis Harvey (Schneider 2003). Littler \& Littler (2000: 490, as L. cervicornis) argued that $P$. cervicornis was smaller in habit with smaller surface cells than $P$. corallopsis and therefore distinct from the latter, a position accepted by Dawes \& Mathieson (2008). More recently, specimens of P. cervicornis and P. corallopsis collected from the Florida Keys were included in a phylogenetic analysis that supported these species as unique (Collado-Vides et al. 2017).

Specimens field-identified as Palisada corallopsis from Bermuda and the Florida Keys are genetically variable in both COI-5P and $r b c \mathrm{~L}$ analyses. For the latter gene, one genetic entity from Bermuda is closely related (0.6\% divergence) to a specimen from Caribbean Mexico likewise identified as $P$. corallopsis, and considered to be representative of the species due to its proximity to the type locality (Cuba). Collado-Vides et al. (2017) published an $r b c \mathrm{~L}$ sequence of P. corallopis from material collected in Florida that differed by $0.4 \%$ from the Caribbean Mexico specimen sequence, similar to the genetic divergence seen between the latter and Bermuda specimens. The other genetic entity from Bermuda previously identified as $P$. corallopsis aligns instead with specimens of $P$. cervicornis also reported by ColladoVides et al. (2017) with $0.9 \%$ divergence in $r b c \mathrm{~L}$ between the sequences. A third undescribed species that we collected in the Florida Keys is sister to P. cervicornis from Bermuda and Florida (2.0\% divergence in $r b c \mathrm{~L}$, Table 1$)$.

Our collections grouping with Caribbean specimens identified as Palisada corallopis cannot be distinguished from Montagne's (1842) protologue of Sphaerococcus corallopsis Montagne (now P. corallopsis) from Havana, Cuba. Our specimens grouping with $L$. cervicornis from Florida are morphologically indistinguishable from the Collins et al. (1917) Bermuda specimens in P.B.-A. (no. 2187), except for the presence of uniform medullary cell wall thickenings in the recently collected Bermuda specimens. These were not found when examining Collins's specimens. However, both are in accordance with the original description of L. cervicornis provided by Harvey (1853). Without genetic sequencing, we have opted to leave P.B.-A. (no. 2187) under this name as Harvey called it, with the assumption that cell wall thickening is a variable trait.

The absence of lenticular thickenings is also observed when comparing recent Bermuda collections of Palisada cervicornis and $P$. corallopis, the latter species lacking this character. Palisada cervicornis specimens from Bermuda have thinner main axes, though this may simply be a result of younger age. In Bermuda specimens, surface cell diameters are also marginally smaller in P. cervicornis $(18-30 \mu \mathrm{m})$ compared to P. corallopsis $(23-45 \mu \mathrm{m})$, in line with the observations for Caribbean isolates (Littler \& Littler 2000). Other Palisada specimens in this clade collected in Key West are morphologically distinct from the two Bermuda species as well as P. cervicornis specimens described by Collado-Vides et al. (2017) from Florida (Table 4). Further study is required to determine whether 
TABLE 4. - Morphological character comparisons for treatments of Palisada cervicornis (Harvey) Collado-Vides, Cassano \& M.T.Fujii, P. corallopsis (Montagne) Sentíes, M.T.Fujii \& Díaz-Larrea and P. furcata (Cordeiro-Marino \& M.T.Fujii) Cassano \& M.T.Fujii.

\begin{tabular}{|c|c|c|c|c|c|c|}
\hline & $\begin{array}{l}\text { Sphaerococcus } \\
\text { corallopsis } \\
\text { (protologue) }\end{array}$ & $\begin{array}{l}\text { Palisada } \\
\text { corallopsis }\end{array}$ & $\begin{array}{l}\text { Palisada } \\
\text { cervicornis }\end{array}$ & $\begin{array}{l}\text { Palisada } \\
\text { cervicornis }\end{array}$ & $\begin{array}{l}\text { Laurencia } \\
\text { cervicornis } \\
\text { (protologue) }\end{array}$ & Palisada furcata \\
\hline $\begin{array}{l}\text { Location of } \\
\text { specimens used } \\
\text { for data }\end{array}$ & $\begin{array}{l}\text { Havana, Cuba (type } \\
\text { locality) }\end{array}$ & Bermuda & Bermuda & $\begin{array}{l}\text { Florida Keys - } \\
\text { cultured in vitro }\end{array}$ & $\begin{array}{l}\text { Key West, Florida } \\
\text { (type locality) }\end{array}$ & $\begin{array}{l}\text { Brazil (type } \\
\text { locality) }\end{array}$ \\
\hline $\begin{array}{l}\text { Length of upright } \\
\text { axes }(\mathrm{cm})\end{array}$ & - & to 8 & to 2 & $5-6(<1$ in field $)$ & to 4 & to 15 \\
\hline $\begin{array}{l}\text { Main axis basal } \\
\text { diam. }(\mathrm{mm})\end{array}$ & - & $1.5-2.0$ & $0.5-1.0$ & - & - & $1.3-1.5$ \\
\hline Branching pattern & $\begin{array}{l}\text { Irregularly } \\
\text { dichotomous } \\
\text { or whorled; } \\
\text { dichotomous } \\
\text { above with short } \\
\text { nearly dichtomous } \\
\text { branchlets solitary } \\
\text { or in clusters }\end{array}$ & $\begin{array}{l}\text { Irregularly } \\
\text { cervicorn; apices } \\
\text { often appearing } \\
\text { dichotomous; } \\
\text { some } \\
\text { adventitious } \\
\text { branching }\end{array}$ & $\begin{array}{l}\text { Irregularly palmate; } \\
\text { branches varying } \\
\text { in width/length } \\
\text { at each node; to } \\
10 \text { branches per } \\
\text { node }\end{array}$ & $\begin{array}{l}\text { Scarcely branched, } \\
\text { irregular to } \\
\text { dichotomous } \\
\text { usually with 1-2 } \\
\text { orders of branches }\end{array}$ & $\begin{array}{l}\text { Irregularly } \\
\text { branched to } \\
\text { subdichotomous; } \\
\text { secondary } \\
\text { branches curved } \\
\text { upwards }\end{array}$ & $\begin{array}{l}\text { Dichotomously, } \\
\text { trichotomously } \\
\text { to irregularly } \\
\text { branched, more } \\
\text { densely in upper } \\
\text { portions }\end{array}$ \\
\hline $\begin{array}{l}\text { Branchlet diam. } \\
(\mathrm{mm})\end{array}$ & $1-2$ & $1-2$ & to 1.5 & $0.7-1.2$ & to 2 & $1.0-1.5$ \\
\hline Branchlet tips & $\begin{array}{l}\text { Slightly swollen } \\
\text { with apical pit; } \\
\text { trichoblasts } \\
\text { present }\end{array}$ & $\begin{array}{l}\text { Swollen; broad } \\
\text { in proportion } \\
\text { to length; } \\
\text { trichoblasts } \\
\text { present }\end{array}$ & $\begin{array}{l}\text { Slightly swollen; } \\
\text { trichoblasts } \\
\text { present }\end{array}$ & - & $\begin{array}{l}\text { Cylindrical; broad } \\
\text { in proportion } \\
\text { to length; } \\
\text { trichoblasts } \\
\text { present }\end{array}$ & $\begin{array}{l}\text { Cylindrical } \\
\text { to slightly } \\
\text { flattened; tips } \\
\text { obtuse }\end{array}$ \\
\hline $\begin{array}{l}\text { Secondary pit- } \\
\text { connections }\end{array}$ & - & Present & Present & Present & - & Present \\
\hline Medullary cells & - & - & - & $\begin{array}{l}\text { Rounded or slightly } \\
\text { radially elongated; } \\
51-101 \text { long, } \\
\text { 30-83 wide }\end{array}$ & - & $\begin{array}{l}\text { Slightly rounded; } \\
50-150 \text { long, } \\
\text { 45-135 wide }\end{array}$ \\
\hline $\begin{array}{l}\text { Lenticular } \\
\text { thickenings }\end{array}$ & - & Absent & $\begin{array}{l}\text { Uniform cell } \\
\text { wall thickening } \\
\text { present }\end{array}$ & $\begin{array}{l}\text { Absent (but } \\
\text { medullary cell } \\
\text { walls uniformly } \\
\text { thickened) }\end{array}$ & - & - \\
\hline Corps en cerise & - & - & - & - & - & Absent \\
\hline $\begin{array}{l}\text { Outer cortex cell in } \\
\text { surface view }\end{array}$ & - & $\begin{array}{l}\text { Polygonal } \\
\text { (hexagonal- } \\
\text { rectangular) }\end{array}$ & $\begin{array}{l}\text { Polygonal } \\
\text { (hexagonal) }\end{array}$ & $\begin{array}{l}\text { Polygonal and } \\
\text { isodiametric }\end{array}$ & - & $\begin{array}{l}\text { Polygonal and } \\
\text { isodiametric }\end{array}$ \\
\hline $\begin{array}{l}\text { Outer cortex cell } \\
\text { diam. }(\mu \mathrm{m}), \\
\text { surface view }\end{array}$ & - & $23-45$ & $18-30$ & $16-34$ (22-48 long) & - & 7-33 (21-33 long) \\
\hline $\begin{array}{l}\text { Outer cortex cell } \\
\text { projections }\end{array}$ & - & Absent & Absent & - & - & Absent \\
\hline $\begin{array}{l}\text { Tetrasporangium } \\
\text { diam. }(\mu \mathrm{m})\end{array}$ & - & - & - & $38-91$ & - & $60-75$ \\
\hline References & Montagne 1842 & Present study & Present study & $\begin{array}{l}\text { Collado-Vides et al. } \\
2017\end{array}$ & Harvey 1853 & $\begin{array}{l}\text { Fujii \& Sentíes } \\
2005\end{array}$ \\
\hline
\end{tabular}

the Key West collections represent a known or novel species of Palisada.

Palisada furcata from Brazil also groups in the P. corallopsis clade, with $1.8 \%$ divergence from its closest congener, P. corallopsis from Mexico. But there are 14 ambiguities in the P. furcata sequence, so that distance estimate is likely to change with better quality sequence data. While the phylogenetic relationship of $P$. furcata to $P$. corallopsis is unresolved in our analysis (Fig. 1), the close grouping warrants comparing the morphological characters for these species (Table 4). Palisada furcata can be distinguished from $P$. corallopsis morphologically by its larger overall habit, cylindrical to slightly flattened (vs. swollen) branchlet tips, and smaller outer cortical cells.
Unfortunately, we did not collect fertile $P$. corallopsis to compare tetrasporangia, a character that has not been described for this species in previous publications.

\section{THE GENUS YUZURUA IN BERMUDA}

Reports of the species currently known as Yuzurua poiteaui appear in the earliest literature for Bermuda as Laurencia gemmifera Harvey (Rein 1873; Dickie 1874; Hemsley 1884). This species was archived pro parte as P.B.-A. no. 1937 (as L. tuberculosa; Collins et al. 1913), and as mentioned above, represents $Y$. poiteaui in a heterotypic collection; however a specimen of the same P.B.-A. number in another fascicle can be attributed to L. intricata. Collins \& Hervey (1917) 
first reported the species in Bermuda as Laurencia poiteaui (J.V.Lamouroux) M.Howe. This name was later transferred to Chondrophycus (Nam 1999) and then to Palisada (Nam 2006, 2007) based on phylogenetic and morphological evidence. Using the $r b c \mathrm{~L}$ sequences of $Y$. poiteaui (as Chondrophycus poiteaui (J.V.Lamouroux) K.W.Nam) and C. gemmiferus (Harvey) Garbary \& J.T.Harper, Díaz-Larrea et al. (2007) concluded that the latter species, different only in minor anatomical characters and should be reduced to a synonym of Palisada poiteaui (J.V.Lamouroux) K.W.Nam (Sentíes \& Diaz-Larrea 2008). Molecular data have also prompted the elevation of Yuzurua, initially a subgenus of Chondrophycus recognized by Nam (1999), to the generic level (MartinLescanne et al. 2010) with $Y$. poiteaui as the generitype. This species appears to be relatively rare in Bermuda at present, with only one collection confirmed with molecular data (intraspecific divergence of $0.2 \%$ in $r b c \mathrm{~L}$ ). Yuzurua poiteaui specimens were far more abundant in our Florida Keys and US Virgin Islands collections.

Sequence data have shown that Palisada iridescens (M.J.Wynne \& D.L.Ballantine) K.W.Nam was closely related to Yuzurua, and the new combination, $Y$. iridescens was proposed (Sentíes et al. 2015). Our data agree with this transfer, as previous records of this species in Bermuda (Schneider \& Lane 2007, as Chondrophycus iridescens) grouped with the Yuzurua clade in both our COI-5P and $r b c \mathrm{~L}$ barcode analyses (Table 1) and $r b c \mathrm{~L}$ phylogeny (Fig. 1). While sequence data for $Y$. iridescens from Guadeloupe, Mexico and St. Kitts are available in GenBank, we chose to exclude these data from our analysis. The sequences of $Y$. iridescens from St. Kitts and Guadeloupe were short (886 bp and 660 bp, respectively) and only overlapped by 173 bp with our $r b c \mathrm{~L}$ sequences, an inadequate number for meaningful comparison. Furthermore, the three sequences of $Y$. iridescens from Senties et al. (2015) deposited in GenBank are quite variable, despite their stating that the divergence among them was extremely low at $0.01-0.02 \%$. Our analysis shows much larger distance values of 1.4-5.5\%. It is clear that the L. iridescens complex needs reassessment so these issues can be resolved. Additional genes and longer sequences from specimens at or near the type locality will be imperative for definitive phylogenetic results.

Our analysis has also resolved a unique sequence from a Bermuda specimen in this clade sister to Yuzurua poiteaui (4.3\% divergence). Thus far, we are able to confirm only a single specimen representing this entity and will require additional collections before we can verify that these represent a unique third species in the genus. At present, this taxon will be regarded as Yuzurua sp. 1Bda (Fig. 1; Appendix 1).

\section{THE GENUS LAURENCIELLA IN BERMUDA}

The genus Laurenciella was segregated from Laurencia (Cassano et al. 2012b) on the basis of molecular sequence data, which showed it to be a distinct clade despite its generic features being indistinguishable from those of Laurencia. The type of the genus, Laurenciella marilzae (Gil-Rodriguez, Sentíes, Diaz-Larrea, Cassano \& M.T.Fujii) Gil-Rodriguez, Sentíes, Diaz-Larrea, Cassano \& M.T.Fujii, was originally described from the Canary
Islands (Gil-Rodriguez et al. 2009, as Laurencia marilzae GilRodriguez, Senties, Díaz-Larrea, Cassano \& M.T.Fujii) based on $r b c \mathrm{~L}$ sequences and characterized morphologically by the distinctive yellow-orange color of its habit (Fig. 4A), cortical cells that project markedly in cross-section, and the presence of 'corps en cerise' in all cells of the thallus. Corroborating evidence from both molecular and morphological analyses of specimens collected in the Mexican Caribbean showed that this species was also present in the tropical western Atlantic Ocean (Sentíes et al. 2011). More recently, a second species from the genus, L. mayaimii Collado-Vides, Cassano \& M.T.Fujii, was described from Florida (Collado-Vides et al. 2018).

Our molecular findings show a clear relationship between Laurenciella marilzae and specimens that we collected in Bermuda and the Florida Keys. Both genetic variation (3.9\% divergence in $r b c \mathrm{~L}$ ) and differences in overall habit morphology suggested that these latter collections were a distinct second species of the genus, described herein as L. namii Popolizio, C.W.Schneider \& C.E.Lane, sp. nov. Not excepting the shared features of Laurenciella and Laurencia sensu stricto (i.e., four pericentral cells in axial segments; presence of 'corps en cerise'; presence of secondary pit connections), microscopic vegetative characters of $L$. marilzae and $L$. namii sp. nov. predominantly overlap (Table 5). In particular, the size and shape of outer cortical cells (Fig. 4D, F), the size and shape of medullary cells (Fig. 4E), the conspicuous projecting of cortical cells in cross-section (Fig. 4D) and the presence of trichoblasts with 3-4 orders of subdichotomous branching all represent shared characteristics (Fig. 4F, G). In addition, Bermuda and the Florida Keys specimens of $L$. namii sp. nov. are distinctly yellow-orange in color (Fig. 4A, B), an identifying feature that is noted for specimens of $L$. marilzae from the type locality and from the Caribbean Sea. However, this does not appear to be a characteristic of the genus as a whole because deepoccurring Brazilian specimens (Rocha-Jorge et al. 2010), as well as an undescribed genetic isolate (Laurenciella sp. 1Bda; Fig. 1), are markedly red in color.

Though the vegetative anatomy appears to be largely cryptic between Laurenciella marilzae and L. namii sp. nov., the two species are quite distinct in overall habit. Laurenciella namii sp. nov. reaches twice the height of L. marilzae and has a thallus texture that is fleshy rather than cartilaginous. The main axes of L. namii sp. nov. are slender and are distinctly lax (Fig. 4A), never displaying the characteristic "turf" form possessed by L. marilzae in the Caribbean (Sentíes et al. 2011). Branching patterns in L. namii sp. nov. are more irregular than alternate (Fig. 4A, B), with upper portions of the thallus tending to be profusely branched, whereas lower portions are often denuded at maturity (Fig. 4A). The habitats of both Caribbean and Canary Islands specimens of $L$. marilzae are documented as exposed sites in the low intertidal zone (Gil-Rodriguez et al. 2009, Sentíes et al. 2011). Our collections of L. namii sp. nov. from Bermuda and Florida are exclusively found in the subtidal and are especially common in shallow, relatively protected habitats at both locations.

Therefore, after a thorough assessment of species in the 'Laurencia-complex' from the western Atlantic, we deter- 
TABLE 5. - Morphological character comparisons of the species of Laurenciella Cassano, Gil-Rodríguez, Senties, Díaz-Larrea, M.C.Oliveira \& M.T.Fujii.

\begin{tabular}{|c|c|c|c|}
\hline & Laurenciella marlizae & Laurenciella mayaimii & Laurenciella namii sp. nov. \\
\hline Thallus color & $\begin{array}{l}\text { main axes yellow-orange, ultimate } \\
\text { branches rosy red }\end{array}$ & \multicolumn{2}{|c|}{$\begin{array}{l}\text { main axes brownish-yellow, ultimate main axes yellow to orange, ultimate } \\
\text { branches rosy red } \\
\text { branches deep rosy red }\end{array}$} \\
\hline Length of upright axes $(\mathrm{cm})$ & to 7 & to 6 & to 15 \\
\hline Main axis basal diam. (mm) & to 1.5 & to 0.9 & to 1 \\
\hline Branching pattern & irregularly alternate and spiral & subopposite to spirally alternate & subopposite to spirally alternate \\
\hline Branchlet diam. $(\mu \mathrm{m})$ & $540-820$ & $410-430$ & $140-350$ \\
\hline Secondary pit-connections & present & present & present \\
\hline Corps en cerise & present, one per cortical cell & present, one per cortical cell & present, one per cortical cell \\
\hline $\begin{array}{l}\text { Outer cortex cell in surface } \\
\text { view }\end{array}$ & $\begin{array}{l}\text { isodiametric-polygonal above, } \\
\text { elongate-polygonal below }\end{array}$ & isodiametric-polygonal & $\begin{array}{l}\text { irregularly rounded polygonal to ovoid } \\
\text { above, elongate-polygonal below }\end{array}$ \\
\hline $\begin{array}{l}\text { Outer cortex cell diam. in } \\
\text { surface view }(\mu \mathrm{m})\end{array}$ & $28-53$ & $20-89$ & $20-49$ \\
\hline \multicolumn{2}{|c|}{ Outer cortex cell projections present } & present & present \\
\hline Medullary cells diam. $(\mu \mathrm{m})$ & $10-100$ & - & $30-115$ \\
\hline Known distribution & $\begin{array}{l}\text { Canary Is., Azores, Mediterranean } \\
\text { Sea, Brazil, Mexico }\end{array}$ & Florida & Bermuda, Florida \\
\hline References & $\begin{array}{l}\text { Gil-Rodriguez et al. } 2009 \text { (as } \\
\text { Laurencia marilzae) }\end{array}$ & Collado-Vides et al. 2018 & $\begin{array}{l}\text { Present study; Collado-Vides et al. } \\
\text { 2018, as L. sp. Florida }\end{array}$ \\
\hline
\end{tabular}

mined that our specimens of Laurenciella namii sp. nov. are unique. We did consider the historical name Laurencia obtusa var. gracilis (C.Agardh) Kützing based on the illustrations and description of Kützing (1865), which we interpreted as "delicate branches spreading widely," and of Collins \& Hervey (1917) who describe it as a "delicate, soft and slender form." Without seeing the original Chondria obtusa var. gracilis in Lund that Agardh (1822) reported from the West Indies, we believe linking this variety to the new species of Laurenciella would be unwise at present. We did not observe Laurencia obtusa var. gracilis in our collections from St. Croix in the West Indies, the type locality of this variety. Interestingly, images of specimens from Bermuda with the characteristics of Laurenciella namii sp. nov., also previously identified as Laurencia obtusa, can be found illustrated on the Macroalgal Herbarium Portal (https://macroalgae.org/portal/collections/ index.php), so this large species in the complex has been an important member of the flora as long as specimens have been collected in the islands.

A second genetically distinct species of Laurenciella from Bermuda has been discovered in this study. Based on $r b c \mathrm{~L}$ sequences, the closest neighbor to 'Laurenciella sp. 1Bda' (Fig. 1) is an undescribed specimen from Brazil, Laurenciella sp. 2 (Cassano et al. 2012b) from which it differs by $0.4 \%$. These likely represent a single species of Laurenciella with a broad distribution in the western Atlantic. A second undescribed species from Brazil, Laurenciella sp. 3 (Cassano et al. $2012 \mathrm{~b}$ ) is closely related to these, with $0.9 \%$ divergence in $r b c \mathrm{~L}$. As with Yuzurua sp. 1Bda, we have confirmed only a single collection representing this taxon.

\section{The GENUS CHONDROPHYCUS IN BERMUDA}

Our COI-5P and $r b c \mathrm{~L}$ barcode analyses (Table 1) uncovered a unique taxon in the genus Chondrophycus from Bermuda, herein described as C. planiparvus Popolizio, C.W.Schneider \& C.E.Lane, sp. nov. Sequences from Chondrophycus cf. undulatus (Yamada) Garbary \& J.T.Harper and C. dotyi (Y.Saito)
K.W.Nam collected in the Hawaiian Islands, grouped with our new Bermuda species in COI-5P barcode gap analysis (Table 1 ). In the $r b c \mathrm{~L}$ analysis, $C$. planiparvus sp. nov. differs by only $0.5 \%$ from an undescribed specimen collected from Flower Garden Banks, Gulf of Mexico (Fujii et al. 2006) (Table 1 and Fig. 1), and these may represent the same species. The two taxa are arranged as a sister grouping to the rest of the Chondrophycus clade, which consists of $C$. dotyi from Hawaii, C. anabeliae Sentíes, M.T.Fujii, Cassano \& Dreckmann from Caribbean Mexico, C. tronoi (E.GanzonFortes) K.W.Nam from the Philippines, C. cf. undulatus from New Caledonia and several undescribed species from South Africa, Australia or New Caledonia. The recently described $C$. anabeliae from the Caribbean (Sentíes et al. 2016) has terete axes, but these are occasionally partially compressed. It bears little morphological resemblance to C. planiparvus sp. nov.

Saito (1967) split the genus Laurencia into two subgenera, Laurencia and Chondrophycus, on the basis of tetrasporangial development relative to the axis (parallel or right-angle) and presence or absence of secondary pit connections between cortical cells. He later determined these features were unreliable since some species possessed features of both subgenera, namely, a parallel arrangement of tetrasporangia and lack of secondary pit-connections (Saito 1982). Species exhibiting this combination of characters would later be attributed to Osmundea (Nam et al. 1994). Ultimately, Garbary \& Harper (1998) elevated the subgenus Chondrophycus to generic rank based on morphological cladistics, including the absence of secondary pit connections.

Nam (1999) proposed an infrageneric classification scheme for Chondrophycus including four subgenera-Chondrophycus, Kangjaewonia, Palisada and Yuzurua. Members of the subgenus Chondrophycus (containing C. cartilagineus (Yamada) Garbary \& J.T.Harper as the type, as well as several others) exhibit right-angle development of tetrasporangia but lack secondary pit connections. For species displaying both 
TABLE 6. - Morphological character and habitat comparisons for species of Chondrophycus (J.Tokida \& Y.Saito) Garbary \& J.T.Harper with compressed axes.

\begin{tabular}{|c|c|c|c|c|c|}
\hline & C. dotyi & C. kangjaewonii & C. planiparvus sp. nov. & C. succisus & C. undulatus \\
\hline Type locality & Hawaii & Korea & Bermuda & Australia & Japan \\
\hline Length of upright axes & $\begin{array}{l}\text { to } 5 \mathrm{~cm} \\
\text { (subcompressed) }\end{array}$ & $\begin{array}{l}\text { to } 10 \mathrm{~cm} \\
\text { (compressed) }\end{array}$ & to $2 \mathrm{~cm}$ (compressed) & $\begin{array}{l}\text { to } 8 \mathrm{~cm} \\
\text { (compressed) }\end{array}$ & $\begin{array}{l}\text { to } 7 \mathrm{~cm} \\
\text { (compressed) }\end{array}$ \\
\hline Branching pattern & $\begin{array}{l}\text { Distichous; } \\
\text { alternate, opposite } \\
\text { or irregular }\end{array}$ & \multicolumn{2}{|c|}{$\begin{array}{r}\text { Distichous; alternateDistichous; irregular to } \\
\text { alternate or opposite }\end{array}$} & \multicolumn{2}{|c|}{$\begin{array}{l}\text { Distichous; oppositeDistichous; opposite } \\
\text { (pinnate) or } \quad \text { (pinnate) } \\
\text { alternate }\end{array}$} \\
\hline Secondary pit connections & Absent & Absent & $\begin{array}{l}\text { Present (abundant, } \\
\text { conspicuous) }\end{array}$ & Absent & Absent \\
\hline Outer cortex cells surface view & Nearly isodiametric & Elongated ovoid & $\begin{array}{l}\text { Ovoid in upper regions } \\
\text { of branches, irregularly } \\
\text { angular and elongated } \\
\text { below }\end{array}$ & $\begin{array}{l}\text { Rounded polygonal } \\
\text { to longitudinally } \\
\text { elongate }\end{array}$ & Quadrangular \\
\hline Outer cortex cell projection & $\begin{array}{l}\text { Domed projections } \\
\text { present in ultimate } \\
\text { branchlets }\end{array}$ & $\begin{array}{l}\text { Absent or } \\
\text { occasionally } \\
\text { slightly projecting } \\
\text { at branch apices }\end{array}$ & $\begin{array}{l}\text { Cortical cell projections } \\
\text { present at most } \\
\text { branch apices }\end{array}$ & Absent & Absent \\
\hline Tetrasporangial arrangement & Right-angle & Parallel & Right-angle & Right-angle & Right-angle \\
\hline Tetrasporangia diam. $(\mu \mathrm{m})$ & Not reported & $180-230$ & $43-68$ & Not reported & to 110 \\
\hline Habitat & $\begin{array}{l}\text { Intertidal; on eroded } \\
\text { coral and basalt } \\
\text { platforms }\end{array}$ & $\begin{array}{l}\text { Lower intertidal on } \\
\text { rock or coral or } \\
\text { subtidal to } 3 \mathrm{~m}\end{array}$ & $\begin{array}{l}\text { From } 13-23 \text { m on coral; } \\
\text { never intertidal }\end{array}$ & $\begin{array}{l}\text { Intertidal; on eroded } \\
\text { coral and basalt } \\
\text { pools }\end{array}$ & $\begin{array}{l}\text { Lower intertidal, } \\
\text { more commonly } \\
\text { on basalt rock }\end{array}$ \\
\hline References & $\begin{array}{l}\text { Saito 1969; Abbott } \\
1999\end{array}$ & $\begin{array}{l}\text { Nam \& Sohn 1994, } \\
\text { Nam } 1999\end{array}$ & Present study & $\begin{array}{l}\text { Cribb 1958; Saito } \\
\text { 1969; Abbott } 1999\end{array}$ & $\begin{array}{l}\text { Yamada 1931; } \\
\text { Tseng 1943; Nam } \\
\text { 1999; Abbott } 1999\end{array}$ \\
\hline
\end{tabular}

right-angle arrangement of tetrasporangia and secondary pit connections, Nam (1999) circumscribed the subgenus Yuzurua, which has since been elevated to generic status and is unquestionably distinct from Chondrophycus in phylogenetic analyses (Martin-Lescanne et al. 2010). Furthermore, Nam (1999) defined the section Parvipapillatae for members of subgenus Yuzurua demonstrating epidermal cell projections at branchlet apices in transverse section, and designated C. parvipapillatus (C.K.Tseng) Garbary \& J.T.Harper as the type species of this section. Later, Nam (2006) proposed the genus Palisada following a morphological cladistics analysis that resolved two paraphyletic clades of Chondrophycus species. Chondrophycus parvipapillatus fell into the clade that did not include $C$. cartilagineus, the generitype, and thus was transferred to Palisada.

Interestingly, our specimens of Chondrophycus planiparvus Popolizio, C.W.Schneider \& C.E.Lane, sp. nov. from Bermuda exhibit the three traits that Nam (2006) used to segregate Palisada parvipapillata (C.K.Tseng) K.W.Nam to Palisada: a right-angle arrangement of tetrasporangia, production of secondary pit connections and apical cortical cell projections. Secondary pit connections are noted to be sporadic in $P$. parvipapillata, but are frequent and conspicuous in $C$. planiparvus sp. nov., and in the former species, cortical cell projections are present throughout the thallus, whereas these are only occasionally seen in the latter, strictly at branch apices. In our analyses, COI-5P sequence data from a Hawaiian specimen of $P$. parvipapillata place the species within the genus Palisada (Table 1), providing molecular evidence for its correct position in the genus and dismissing it as a possible range extension from Bermuda species, despite some morphological similarities.
Table 6 delineates the morphological differences Chondrophycus planiparvus Popolizio, C.W.Schneider \& C.E.Lane, sp. nov. has with congeners having compressed or flattened axes. Our Bermuda species is distinguished from these in having upright axes $2 \mathrm{~cm}$ long or smaller (Fig. 5A-D) and by the conspicuous secondary pit connections present between cortical cells (Fig. 5D, H), a character that historically has been used to segregate morphological subclades of taxa. Chondrophycus planiparvus sp. nov. represents the only current species of the genus that possesses secondary pit connections. However, this trait is not synapomorphic in other genera in the Laurencia complex, including its sister genus Osmundea. McIvor et al. (2002) suggested that secondary pit connections may be an ancestral state that was subsequently lost in some lineages or species in the complex, a concept that is not easily rationalized given our poor knowledge of pit connection functionality on the whole. Nevertheless, the presence of this character in the Bermuda specimens provides an interesting contrast to other members of the genus. Of the species of Chondrophycus exhibiting compressed axes, only C. kangjaewonii (K.W.Nam \& C.H.Sohn) Garbary \& J.T.Harper lacks sequence data available from GenBank, but this species is easily distinguished from C. planiparvus sp. nov. by its parallel arrangement of tetrasporangia, which are also three or four times larger.

Notably, all of the compressed species of the genus from the Pacific Ocean are found in intertidal habitats (or shallow subtidal, as in C. kangjaewonii). Chondrophycus planiparvus Popolizio, C.W.Schneider \& C.E.Lane, sp. nov. specimens have been collected exclusively in subtidal waters off the south shore of Bermuda, from depths of 13-23 m during December-March, when water temperatures in Bermuda are at their lowest. These findings suggest that this novel species 
is adapted to cooler water temperatures and lower light levels than its most similar congeners.

\section{CONCLUSIONS}

Along with the two new species from Bermuda, Laurenciella namii Popolizio, C.W.Schneider \& C.E.Lane, sp. nov. and Chondrophycus planiparvus Popolizio, C.W.Schneider \& C.E.Lane, sp. nov., we distinguish the formerly synonymized Palisada cervicornis from $P$. corallopsis in Bermuda, present the first report of the Indo-Pacific species P. flagellifera in the islands, and provide the first detailed description of Laurencia microcladia from the type locality (Caribbean Sea). Further, two genetic species that have historically been identified as L. obtusa in Bermuda are shown to be distinct from isolates of that taxon from near its type locality (England). These have been determined to be $L$. dendroidea and $L$. catarinensis, both with type localities in Brazil. Therefore, L. obtusa is removed from the Bermuda flora.

Much of the recent research effort on the Laurencia complex has been focused on $r b c \mathrm{~L}$ gene sequencing. While this has resulted in rich comparative data that are useful for assigning specimens to species as well as genera, $r b c \mathrm{~L}$ has not been shown to be an effective marker for resolving relationships at the deeper nodes of the phylogeny in this group. The unsupported intergeneric relationships described above in the molecular results section demonstrate the need for further research that integrates additional taxa (including archival type specimens or recent topotype specimens) and genes with rigorous phylogenetic analyses to produce a bona fide evolutionary framework for the Laurencia complex.

\section{Acknowledgements}

Dr Struan Smith and Roger Simmons of the Bermuda Aquarium, Natural History Museum and Zoo (BAMZ), Drs Jan Locke and Sarah Manuel of the Bermuda Zoological Society and Kaitlin Noyes of the Bermuda Institute of Ocean Sciences (BIOS) provided logistical support while in Bermuda. Additional thanks to Dr. Michael Wynne (MICH) for loaning specimens from the West Indies, and to Drs Yola Metti, Caitlynne Francis and Abel Sentíes for providing sequence data for comparative work. We are grateful for the efforts of Tanya Moore (UNB), Alyssa Rogers (URI) and Kristina Terpis (URI) who produced some of the sequence data for this project. CWS and CEL were funded by NSF DEB grants 1120688 and 1120652 and CWS by the Charles A. Dana Foundation. TRP was partially funded by Rhode Island EPSCoR (Experimental Program to Stimulate Competitive Research). Much of this research was facilitated by work conducted at the Rhode Island Genomics and Sequencing Center, supported in part by the National Science Foundation under EPSCoR Grants Nos. 0554548 \& 1004057 . Work completed at UNB was supported by NSERC Discovery funds to GWS. This is contribution no. 289 to the Bermuda Biodiversity Project (BBP) of BAMZ, Department of Environment \& Natural Resources.

\section{REFERENCES}

Аввотт I. A. 1999. - Marine Red Algae of the Hawaiian Islands. Bishop Museum Press, Honolulu, 477 p.

AgARDH C. A. 1822. - Species algarum... Vol. 1(2). Lundae [Lund]: 169-398.

Areces J. A., Sentíes A. \& Zayas C. R. 2003. — Nuevas adiciones al género Laurencia (Ceramiales, Rhodophyta) para el archipiélago cubano. Serie Oceanológica 1: 104-107.

Bernatowicz A. J. 1952. - Seasonal aspects of the Bermuda algal flora. Papers of the Michigan Academy of Science, Arts \& Letters 36: 3-8.

BørGesen F. 1915. — The marine algae of the Danish West Indies. Part 3. Rhodophyceae. Dansk Botanisk Arkiv 3: 1-80.

Brummitt R. K. \& Powell C. E. 1992. - Authors of Plant Names. Royal Botanic Gardens, Kew, 732 p.

Cassano V., Díaz-Larrea J., Sentíes A., Oliveira M. C., Gil Rodríguez M. C. \& FujII M. T. 2009. - Evidence for the conspecificity of Palisada papillosa with P. perforata (Ceramiales, Rhodophyta) from the western and eastern Atlantic Ocean on the basis of morphological and molecular analyses. Phycologia 48: 86-100. https://doi.org/10.2216/0031-8884-48.2.86

Cassano V., Metti Y., Millar A. J. K., Gil-Rodríguez M. C., Sentíes A., Díaz-Larrea J., Oliveira M. C. \& Fuji M. T. 2012a. - Redefining the taxonomic status of Laurencia dendroidea (Ceramiales, Rhodophyta) from Brazil and the Canary Islands. European Journal of Phycology 47: 67-81. https://doi.org /10.1080/09670262.2011.647334

Cassano V., Oliveira M. C., Gil-Rodríguez M. C., Sentíes A., Díaz-Larrea J. \& Fujil M. T. 2012b. — Molecular support for the establishment of the new genus Laurenciella within the Laurencia complex (Ceramiales, Rhodophyta). Botanica Marina 55: 349-357.

Cassano V., Santos G. N., Pestana E. M. S., Nunes J. M. C., Oliveira M. C. \& Fuji M. T. 2019. - Laurencia longiramea sp. nov. for Brazil and an emendation of the generic delineation of Corynecladia (Ceramiales, Rhodophyta). Phycologia 58: 115127. https://doi.org/10.1080/00318884.2018.1523519

Collado-Vides L., Cassano V., Díaz-Larrea J., Duran A., DaSilva-Medeiros A., Sentíes A \& Fuji M. T. 2014. — Spread of the introduced species Laurencia caduciramulosa (Rhodomelaceae, Rhodophyta) to the northwest Atlantic: a morphological and molecular analysis. Phytotaxa 183 (2): 93-107.

Collado-Vides L., Duran A., Armenis E., Cassano V., Burkepile D., Shantz A. A., Palma L., Díaz-Larrea J., Sentíes A. \& FujII M. T. 2017. - Seasonal recruitment and survival strategies of Palisada cervicornis comb. nov. (Ceramiales, Rhodophyta) in coral reefs. Journal of Phycology 53: 1087-1096. https://doi. org/10.1111/jpy.12567

Collado-Vides L., Cassano V., Santos G. N., Sentíes A. \& FujII M. T. 2018. - Molecular and morphological characterization of Laurencia intricata and Laurenciella mayaimii sp. nov. (Ceramiales, Rhodophyta) in South Florida, United States. Phycologia 57: 287-297. https://doi.org/10.2216/17-80.1

Collins F. S. \& Hervey A. B. 1917. - The algae of Bermuda. Proceedings of the American Academy of Arts \& Sciences 53: 1-195.

Collins F. S., Holden I. \& SeTCHell W. A. 1912. - Phycotheca Boreali-Americana (Exsiccata), Algae of North America. Fascicle XXXVIII. Algae of Bermuda. Nos. 1851-1900. Malden, Massachusetts.

Collins F. S., Holden I. \& Setchell W. A. 1913. - Phycotheca Boreali-Americana (Exsiccata), Algae of North America. Fascicle XXXIX. Algae of Bermuda. Nos. 1901-1950. Malden, Massachusetts.

Collins F. S., Holden I. \& Setchell W. A. 1916. - Phycotheca Boreali-Americana (Exsiccata), Algae of North America. Fascicle XLII. Algae of Bermuda. Nos. 2051-2100. Malden, Massachusetts. Collins F. S., Holden I. \& Setchell W. A. 1917. - Phycotheca 
Boreali-Americana (Exsiccata), Algae of North America. Fascicle XLIV. Algae of Bermuda. Nos. 2151-2200. Malden, Massachusetts.

Cordeiro-Marino M. 1978. — Rodofíceas bentônicas marinhas do Estado de Santa Catarina. Rickia 7: 1-243.

CRIBB A. B. 1958. - Records of marine algae from south-eastern Queensland. III. Laurencia Lamx. University of Queensland Papers, Department of Botany 3: 159-191.

Darriba D., Taboada G. L., Doallo R. \& Posada D. 2012. jModelTest 2: more models, new heuristics and parallel computing. Nature Methods 9: 772.

DAWES C. J. \& MATHIESON A. C. 2008. - The Seaweeds of Florida. University Press of Florida, Gainesville, Florida, 591 p.

Díaz-Larrea J., Sentíes A., Fujil M. T., Pedroche F. F. \& Oliveira M. C. 2007. - Molecular evidence for Chondrophycus poiteaui var. gemmiferus comb. et stat. nov. (Ceramiales, Rhodophyta) from the Mexican Caribbean: implications for the taxonomy of the Laurencia complex. Botanica Marina 50: 250256. https://doi.org/10.1515/BOT.2007.026

DiCKIE G. 1874. - I. On the marine algae of St. Thomas and the Bermudas, and on Halophila baillonis, Asch., in HOOKER J. D., Contributions to the botany of the expedition of H.M.S. 'Challenger'. Journal of the Linnean Society, Botany 14: 311-317. https:// doi.org/10.1111/j.1095-8339.1874.tb00315.x

Figueiredo M. A. O., Barreto M. B. B. \& Reis R. P. 2004. Caracterização das macroalgas nas comunidades marinhas da área de Proteção Ambiental de Cairuçú, Parati, RJ - subsídios para futuros monitoramentos. Revista Brasileira de Botânica 27: 11-17.

Frederick J. J. 1963. - The Marine Algae of the Bermuda Platform. Ph.D. dissertation, University of Michigan, Ann Arbor, 89 p.

Fuji M. T., Cassano V., Stein E. M. \& Carvalho L. C. 2011. Overview of the taxonomy and of the major secondary metabolites and their biological activities related to human health of the Laurencia complex (Ceramiales, Rhodophyta) from Brazil. Revista Brasileira de Farmacognosia 21: 268-282. https://doi. org/10.1590/S0102-695X2011005000064

FujiI M. T., Guimarães S. M. P. B., Gurgel C. \& FredericQ S. 2006. - Characterization and phylogenetic affinities of the red alga Chondrophycus flagelliferus (Rhodomelaceae, Ceramiales) from Brazil on the basis of morphological and molecular evidence. Phycologia 45: 432-441. https://doi.org/10.2216/04-33.1

Fujir M. T. \& Sentíes A. 2005. - Taxonomia do complexo Laurencia (Rhodomelaceae, Rhodophyta) do Brasil, com ênfase nas espécies dos estados de São Paulo e do Espírito Santo. Monografías Ficológicas 2: 69-112.

GARBARY D. J. \& HARPER J. T. 1998. - A phylogenetic analysis of the Laurencia complex (Rhodomelaceae) of the red algae. Cryptogamie, Algologie 19: 185-200.

Gil-Rodríguez M. C., Sentíes A., Díaz-Larrea J., Cassano V. \& FujII M. T. 2009. - Laurencia marilzae sp. nov. (Ceramiales, Rhodophyta) from the Canary Islands, Spain, based on morphological and molecular evidence. Journal of Phycology 45: 264-271. https://doi.org/10.1111/j.1529-8817.2008.00624.x

Gil-Rodríguez M. C., Cassano V., Aylagas E., Sentíes A., DíazLarrea J., Oliveira M. C. \& Fuji M. T. 2010. — Palisada flagellifera (Ceramiales, Rhodophyta) from the Canary Islands, Spain: a new record for the eastern Atlantic Ocean based on morphological and molecular evidence. Botanica Marina 53: 31-40. https://doi.org/10.1515/BOT.2010.010

Guiry M. D. \& Guiry G. M. 2020. — AlgaeBase, world-wide electronic publication, National University of Ireland, Galway. http://www.algaebase.org, accessed on 24 July 2020.

HaRVEY W. H. 1853. - Nereis boreali-americana. Part II. -Rhodospermeae. Smithsonian Contributions to Knowledge 5 (5): 1-258, pls. XIII-XXXVI.

HEMSLEY W. B. 1884. - Algae, i, ii. in, Report of the Botany of the Bermudas and Various Other Islands of the Atlantic and Southern Oceans Report of the Scientific Research of the Exploring Voyage of H.M.S. "Challenger," 1873-1876. Botany 1 (2): 1-135.
Howe M. A. 1918. - Algae. in Britton N. L. (ed.), Flora of Bermuda. Charles Scribner's Sons, New York, $585 \mathrm{p}$.

KEMP A. F. 1857. - Notes on the Bermudas and their natural history, with special reference to their marine algae. Canadian Naturalist and Geologist 2: 145-156.

KÜTZING F. T. 1865. - Tabulae phycologicae. Vol. 15. Gedruckt auf Kosten des Verfassers (in commission bei W. Köhne), Nordhausen, Germany, 36 p.

LAmouroux J. V. F. 1813. - Essai sur les genres de la famille des thalassiophytes non articulées. Annales du Muséum d'histoire naturelle, Paris 20: 131-132.

Le Gall L. \& Saunders G. W. 2010. - DNA barcoding is a powerful tool to uncover algal diversity: a case study of the Phyllophoraceae (Gigartinales, Rhodophyta) in the Canadian flora. Journal of Phycology 46: 374-389. https://doi.org/10.1111/j.15298817.2010.00807.x

LitTler D. S. \& LitTler M. M. 2000. - Caribbean ReefPlants. An Identification Guide to the Reef Plants of the Caribbean, Bahamas, Florida and Gulf of Mexico. Offshore Graphics, Washington, $542 \mathrm{p}$.

Machín-Sánchez M., Cassano V., Díaz-Larrea J., Sentíes A., Fuji M. T. \& Gil-Rodríguez M. C. 2012. — Morphological and molecular evidence demonstrates the amphi-Atlantic distribution of Laurencia catarinensis (Ceramiales, Rhodopyta). Botanica Marina 55: 241-252. https://doi.org/10.1515/bot-2011-0049

MaCHÍN-SÁnCHEZ M., Gil-Rodríguez M. \& Haroun R. 2018. Phylogeography of the red algal Laurencia complex in the Macaronesia region and nearby coastal areas: recent advances and future perspectives. Diversity 10:1-21. https://doi.org/10.3390/ d 10010010

Martin-Lescanne J., Rousseau F., De Reviers B., Payri C., Couloux A., Cruaud C., \& Le Gall L. 2010. - Phylogenetic analyses of the Laurencia complex (Rhodomelaceae, Ceramiales) support recognition of five genera: Chondrophycus, Laurencia, Osmundea, Palisada and Yuzurua stat. nov. European Journal of Phycology 45: 51-61. https://doi.org/10.1080/09670260903314292

MASUDA M., KAWAGUCHI S., TAKAHASHI Y., MATSUO Y. \& SUZUKI M. 1997. - A taxonomic study of the genus Laurencia (Ceramiales, Rhodophyta) from Vietnam. I. Laurencia caduciramulosa Masuda \& Kawaguchi, sp. nov. Cryptogamie, Algologique 18: 1-10. Mateo-Cid E. L., Mendoza-Gonzalez A. C., Sentíes A., DíazLARREA J. \& CALDERÓN J. A. A. 2014. - Laurencia laurahuertana sp. nov. (Rhodomelaceae, Rhodophyta): An epiphytic species from the Mexican Caribbean. Phycological Research 62: 94-101. https://doi.org/10.1111/pre.12043

McIvor L., Maggs C. A., Guiry M. D. \& Hommersand M. H. 2002. - Phylogenetic analysis of the geographically disjunct genus Osmundea Stackhouse (Rhodomelaceae, Rhodophyta). Constancea 83.9.

Metti Y., Millar A. J. K. \& SteInberg P. 2015. - A new molecular phylogeny of the Laurencia complex (Rhodophyta, Rhodomelaceae) and a review of key morphological characters results in a new genus: Coronaphycus, and a description of $C$. novus. Journal of Phycology 51: 929-942. https://doi.org/10.1111/jpy.12333

MONTAGNE C. 1842. - Botanique. Plantes cellulaires, in SAGRA R. de la (ed.), Histoire physique, politique et naturelles de lìle de Cuba. Vol. 11: 549 p.

MurRAY G. 1888. - Catalogue of the marine algae of the West Indian region. I.-Florideae, II.-Phaeophyceae. Journal of Botany, British and Foreign 26: 193-196; 237-243, 303-307; 331-338; 358-363.

NAM K. W. 1999. - Morphology of Chondrophycus undulata and C. parvipapillata and its implications form the taxonomy of the Laurencia (Ceramiales, Rhodophyta) complex. European Journal of Phycology 34: 455-468. https://doi.org/10.1080/095414499 10001718811

Nam K. W. 2006. - Phylogenetic re-evaluation of the Laurencia complex (Rhodophyta) with a description of L. succulenta sp. nov. from Korea. Journal of Applied Phycology 18: 679-607. https:// 
doi.org/10.1007/s10811-006-9073-3

NAM K. W. 2007. - Validation of the generic name Palisada (Rhodomelaceae, Rhodophyta). Algae 22: 53-55. https://doi. org/10.4490/ALGAE.2007.22.2.053

Nam K. W., Choi H. G., Lee S., Park E. J., Kang K. H. \& Kim Y. S. 2000. - Vegetative and reproductive development of Laurencia venusta (Ceramiales, Rhodophyta). Cryptogamie, Algologie 21: 97-110. https://doi.org/10.1016/S0181-1568(00)00109-4

Nam K. W., MagGs C. A. \& Garbary D. J. 1994. - Resurrection of the genus Osmundea with an emendation of the generic delineation of Laurencia (Ceramiales, Rhodophyta). Phycologia 33: 384-395. https://doi.org/10.2216/i0031-8884-33-5-384.1

NAM K. W. \& SOHN C. H. 1994. - Laurencia kangjaewonii sp. nov. (Ceramiales, Rhodophyta) from Korea. Phycologia 33: 397-403. https://doi.org/10.2216/i0031-8884-33-6-397.1

Oliveira Filho E. C. 1977. - Algas Marinhas Bentônicas do Brasil. Tese de Livre Docência, Universidade de São Paulo, São Paulo, 407 p.

Pinheiro-Joventino F., Dantas N. P. \& Maraschin C. D. H. 1998. - Distribuição de algas marinhas no litoral de Fortaleza, Ceará, Brasil. Arquivos de Ciências do Mar 31: 29-40.

Popolizio T. R., Schneider C. W., Chengsupanimit T., SaunDERS G. W. \& LANE C. E. 2013. - Notes on the marine algae of the Bermudas. 13. Helminthocladia kempii sp. nov. (Nemaliales, Liagoraceae) based upon $H$. calvadosii sensu auct. from the western Atlantic. Cryptogamie, Algologie 34: 229-44. https://doi. org/10.7872/crya.v34.iss3.2013.229

ReIN J. J. 1873. — Über die Vegetations- Verhältnisse der BermudasInseln. Bericht uber die Senckenbergische Naturforschende Gesellschaft in Frankfurt am Main, 1872-1873: 131-153.

Rocha-Jorge R., Cassano V., Oliveira M. C. \& Fuji M. T. 2010. - The occurrence of Laurencia marilzae (Ceramiales, Rhodophyta) in Brazil based on morphological and molecular data. Botanica Marina 53: 143-162. https://doi.org/10.1515/ BOT.2010.018

Ronquist F. \& Huelsenbeck J. P. 2003. — MrBayes 3: Bayesian phylogenetic inference under mixed models. Bioinformatics 19: $1572-1574$.

Rousseau F., Gey D., Kurihara A., Maggs C. A., MartinLescanne J., Payri C., De Reviers B., Sherwood A. R. \& Le GALL L. 2017. - Molecular phylogenies support taxonomic revision of three species of Laurencia (Rhodomelaceae, Rhodophyta), with the description of a new genus. European Journal of Taxonomy 269: 1-19.

SAITO Y. 1964. - Contributions to the morphology of the genus Laurencia of Japan. I. Bulletin of the Faculty of Fisheries, Hokkaido University 15: 69-74.

SAITO Y. 1967. - Studies on Japanese species of Laurencia, with special reference to their comparative morphology. Memoirs of the Faculty of Fisheries, Hokkaido University 15: 1-81.

SAITO Y. 1969. - The algal genus Laurencia from the Hawaiian Islands, the Philippine Islands and adjacent areas. Pacific Science 23: $148-160$.

SAITO Y. 1982. - Morphology and infrageneric position of three British species of Laurencia (Ceramiales, Rhodophyta). Phycologia 21: 299-306. https://doi.org/10.2216/i0031-8884-21-3-299.1

Saunders G. W. \& McDevit D. C. 2012. — Methods for DNA barcoding photosynthetic protists emphasizing the macroalgae and diatoms. Methods in Molecular Biology 858: 207-222.

SAunders G. W. \& DrueHL L. 1993. - Revision of the kelp family Alariaceae and the taxonomic affinities of Lessoniopsis Reinke. Hydrobiologia 260/261: 689-697.

Saunders G. W. \& Moore T. E. 2013. - Refinements for the amplification and sequencing of red algal DNA barcode and RedToL phylogenetic markers: a summary of current primers, profiles and strategies. Algae 28: 31-43. https://doi.org/10.4490/ algae.2013.28.1.031

SCHMiTz F. 1889. — Systematische Übersicht der bisher bekannten
Gattungen der Florideen. Flora oder Allgemeine botanische Zeitung 72: 435-456.

SCHNEIDER C. W. 2003. - An annotated checklist and bibliography of the marine macroalgae of the Bermuda islands. Nova Hedwigia 76: 275-361. https://doi.org/10.1127/00295035/2003/0076-0275

SChneider C. W. \& Lane C. E. 2005. - Notes on the marine algae of the Bermudas. 7. Additions to the flora including Chondracanthus saundersii sp. nov. (Rhodophyta, Gigartinaceae) based upon $r b c \mathrm{~L}$ sequence analysis. Phycologia 44: 72-83. https://doi org/10.2216/0031-8884(2005)44[72:NOTMAO]2.0.CO;2

SCHNEIDER C. W. \& LANE C. E. 2007. - Notes on the marine algae of the Bermudas. 8. Further additions to the flora, including Griffithsia aestivana sp. nov. (Ceramiaceae, Rhodophyta) and an update on the alien Cystoseira compressa (Sargassaceae, Heterokontophyta). Botanica Marina 50: 128-140.

Schneider C. W., Lane C. E. \& Saunders G. W. 2010. — Notes on the marine algae of the Bermudas. 11. More additions to the benthic flora and a phylogenetic assessment of Halymenia pseudofloresii Collins \& M. Howe (Halymeniales, Rhodophyta) from its type locality. Phycologia 46: 154-168. https://doi.org/10.2216/ PH09-46.1

Sentíes A., Cassano V., Dreckmann K. M., Gil-RodRíguez, M. C. \& STEIN E. M. \& Fuji M. T. 2016. - Chondrophycus anabeliae (Rhodomelaceae, Ceramiales), a new species in the Laurencia complex from the Mexican Caribbean. Phytotaxa 283 (3): 259-270. https://doi.org/10.11646/phytotaxa.283.3.2

Sentíes A. \& Díaz-Larrea J. 2008. — Proposals for Palisada poiteaui var. gemmifera comb. nov. and Palisada corallopsis comb. nov. (Rhodomelaeae, Rhodophyta). Botanica Marina 51: 69-70. https://doi.org/10.1515/BOT.2008.004

Sentíes A., Díaz-Larrea J., Cassano V., Gil-Rodríguez M. C. \& Fuji M. T. 2011. - Laurencia marilzae (Ceramiales, Rhodophyta) from the Mexican Caribbean: a new record for the tropical western Atlantic. Bulletin of Marine Science 87: 681-686. https:// doi.org/10.5343/bms.2010.1094

Sentíes A., Dreckmann K. M., Hernández O. E., NúÑEz Resendiz M. L., Le GAll L. \& CASSANO V. 2019. — Diversity and distribution of Laurencia sensu stricto (Rhodomelaceae, Rhodophyta) from the Mexican Pacific, including L. mutueae sp. nov. Phycological Research 67: 267-278. https://doi.org/10.1111/pre.12382

Sentíes A., Fujil M. T. \& Rodríguez D. 2001. — Laurencia venusta (Ceramiales, Rhodophyta): a new record from the Atlantic Ocean. Botanica Marina 44: 95-99. https://doi.org/10.1515/ BOT.2001.013

Sentíes A., Wynne M. J., Cassano V., Gil-Rodríguez M. C. \& FujII M. T. 2015. - Yuzurua iridescens (M.J. Wynne \& D.L. Ballantine) comb. nov. (Ceramiales, Rhodophyta) from the Caribbean Sea: morphological and molecular evidence. Brazilian Journal of Botany 38: 605-613. https://doi.org/10.1007/ s40415-015-0154-x

Silvestro D. \& Michalak I. 2011 [2012]. — raxmlGUI: a graphical front-end for RAxML. Organisms Diversity \& Evolution 12: 335-337.

STACKHOUSE J. 1809. - Tentamen marino-cryptogamicum, ordinem novum, in genera et species distributum, in Classe XXIVta Linnaei sistens. Mémoires de la Société Impériale des Naturalistes de Mouscou 2: 50-97.

TANDY G. 1936. - Marine algae. In: Rendle A.B.: Notes on the flora of the Bermudas. Journal of Botany, British and Foreign 74: 42-50, 65-71, 101-112.

TAYLOR W. R. 1960. - Marine Algae of the Eastern Tropical and Subtropical Coasts of the Americas. Univ. Michigan Press, Ann Arbor, 870 p.

TsEng C. K. 1943. - Marine algae of Hong Kong. IV The genus Laurencia. Papers of the Michigan Academy of Science, Arts \& Letters 28: 185-208.

Womersley H. B. S. 2003. - The Marine Benthic Flora of Southern 
Australia - Part IIID Ceramiales - Delesseriaceae, Sarcomeniaceae, Rhodomelaceae., Australian Biological Resources Study \& State Herbarium of South Australia, Canberra \& Adelaide, 533 p.
YAMADA Y. 1931. - Notes on Laurencia, with special reference to the Japanese species. University of California Publications in Botany 16: 185-311.

Submitted on 26 April 2021. accepted on 10 September 2021; published on 26 January 2022. 


\section{APPENDICES}

APPENDIX 1. - Collection details and GenBank accession numbers for isolates included in the molecular analyses of this study. Newly generated GenBank numbers in bold type. For both COI-5P and rbcL genes, we selected one specimen of each newly sequenced species and geographic location for deposit in GenBank. The complete datasets for each gene can be shared upon request. At present, sequence data provided to us from the following are not publicly available: ${ }^{\star \star} \mathrm{M}$. Fujii, ${ }^{* * *}$ V. Cassano.

\section{Taxa}

Acanthophora spicifera (Vahl)

Børgesen

Acanthophora sp.

Alsidium corallinum C.Agardh

Alsidium oliveiranum S.M.Guim. \&

M.T.Fujii

Alsidium seaforthii (Turner) J.Agardh

Alsidium triquetrum (S.G.Gmel.) Trevis.

Bortrychia calliptera (Mont.) Mont.

Bostrychia mixta J.D.Hook. \& Harv.

Bostrychia mortiziana (Kütz.) J.Aga

Bostrychia radicans (Mont.) Mont.

Bostrychia tenella (J.V.Lamour.)

J.Agardh

Coeloclonium umbellatum (Harv.)

J.Agardh

Coeloclonium sp.

Chondria baileyana (Mont. ) Harv.

Chondria californica (Collins) Kylin

Chondria collinsiana M.Howe

Chondria dasyphylla (Woodw.)

C.Agardh

Chondria succulenta (J.Agardh)

Falkenb.

Chondrophycus anabeliae Sentíes,

M.T.Fujii, Cassano \& Dreckmann

Chondrophycus dotyi (Y.Saito)

K.W.Nam

Chondrophycus dotyi

Chondrophycus planiparvus Popolizio,

C.W.Schneid. \& C.E.Lane sp. nov.

Chondrophycus tronoi (Ganzon-

Fortes) K.W.Nam

Chondrophycus undulatus (Yamada)

Garbary \& J.T.Harper

Chondrophycus undulatus

Chondrophycus undulatus

Chondrophycus cf. undulatus

Chondrophycus sp.

Chondrophycus sp.

Chondrophycus sp.

Chondrophycus sp. 1

Chondrophycus sp. 2

Chondrophycus sp. 3

Corynecladia clavata (Sond.) C.Agardh

Corynecladia clavata

Corynecladia elatus (C.Agardh)

Cassano, M.C.Oliveira \& M.T.Fujii

Corynecladia nova (Metti) Cassano,

M.C.Oliveira \& M.T.Fujii

Digenea mexicana G.H.Boo \&

D.Robledo

Digenea rafaelii G.H.Boo, G.Andrade-

Sorcia \& S.M.Boo

Digenea simplex (Wulfen) C.Agardh

Digenea sp.

\section{Voucher/ Collection data}

India, Tamil Nadu coast

Australia, Western Australia, Rottnest Island, 15.III.2015

Spain, Canary Islands, Lanzarote, 13.VI.2018, P. Diaz-Tapia

Brazil, Espirito Santo, Anchieta, Parati Beach, 4.X.2006, M. Fujii

United States, Florida, Fort Pierce, 10.VIII.2013, G. Garcia-Soto

Mexico, Sontecomapan, Vera Cruz, 10.II.1994, J. West \& G. Zuccarello

Saint Helena, Nightingale, Seal Pool and naer shore, 21.III.2010, S. Scott

Indonesia, West Sawang, Sulawesi, 16.XI.1994, J. West \& G. Zuccarello

United States, Mississippi, St. Louis Bay, 11.II.1998, F. Gurgel

American Samoa, Tutuila, 26.VII.1991, B. Rainey

Australia, Western Australia, Rottnest Island, 15.III.2015

Australia, South Australia, Port MacDonnell, 28.VIII.1995, M. Hommersand

Canada, Prince Edward I., Pownal, 29.VII.2008, G. Saunders

United States, California, San Diego Co., Beach Club Reef, La Jolla

Shores, 1.VII.1996, M. Volovsek

Brazil, Rio de Janeiro, Armacao dos Buzios, Praia Rasa, 13.I.2005,

V. Cassano \& J. De-Paula

United States, North Carolina, Carteret Co., Bogue Sound, W. Freshwater

Australia, New South Wales, Batehaven, 30.V.2005, Y. Metti

Mexico, Quintana Roo, Isla Mujeres, 12.Il.2007, A. Sentíes \& M. Gil-

Rodriguez

United States, Hawaii, A. Sherwood (ARS01606)

United States, Hawaii, Oahu, Sandy Beach, 31.V.2015, E. Stein

Bolotype: BDA 0934 [TRP 12-40-13]

Philippines, A. Lluisma

United States, Hawaii, A. Sherwood (ARS02922)

United States, Hawaii, A. Sherwood (ARS02493)

United States, Hawaii, A. Sherwood (ARS00733)

New Caledonia, Loyalty Island, Mare, 22.III.2005, C. Payri

Australia, Norfolk Island, Collins Head, 21.III.2005, Y. Metti \& A. Millar

South Africa, KwaZulu-Natal, Sodwana Bay, Jesser Point, 9.VI.2010,

R. Anderson \& J. Bolton

United States, Texas, Flower Garden Banks Sanctuary, II.2000,

S. Fredericq

New Caledonia, Loyalty Island, Lifou, 26.III.2005, C. Payri

New Caledonia, Loyalty Island, Mare, 21.III.2005, C. Payri

New Caledonia, Loyalty Island, Beautemps/Beaupre, 6.IV.2005, C. Payri

Australia, Victoria, Walkerville, 20.I.2015, P. Díaz-Tapia \& M. Brookes

Australia: Victoria, The Caves, 21.I.2015, P. Diaz-Tapia \& M. Brookes

Australia, Western Australia, Rottnest Island, 15.XI.2008, J. Eu

Australia, NSW, Jervis Bay, Plantation Pt, subtidal, 15.II.2005, Y. Metti \&

A. Millar

Mexico, Playa Xcalococo, Quintana Roo, 19.IV.2018, D. Robledo

Mexico, Bahia de Kino, La Cruses, Sonora, 16.V.2010, S.M. Boo \&

R. Riosmena-Rodriguez

Greece, Saronikos, Gourkolimano, 12.IV.2011, F. Kuepper

Japan, Sesoko Island, Okinawa, 30.VII.2009 $\begin{array}{cc}\text { COI-5P rbcL } & \text { rcession } \\ \text { Accession }\end{array}$

numbers numbers

MT478065

- MF094033

- $\quad$ MN165090

- MN165086

- $\quad \mathrm{MH} 204657$

- MH204654

- $\quad$ AY920806

- MK185794

- $\quad$ AY920813

- AF259497

- AY920836

- $\quad$ MF094052

- $\quad$ MH388575

- KU564500

- $\quad$ AY172578

- $\quad$ AF259497

- U04021

- $\quad$ KY120336

- KX815262

HQ422621

- KX815263

OK209884 OK209859

- $\quad$ AF489864

HQ422996

HQ422752

HQ423055

$-$

KY120338

- KY927795

- $\quad$ AF465817

FJ785309

- FJ785310

- $\quad$ FJ785311

- MF094079

$\mathrm{MH} 704456$

KY120339

- $\quad$ KY120340

- $\quad$ MH514862

- $\quad$ MH514867

MH388507

MH514872 


\begin{tabular}{|c|c|c|c|}
\hline Taxa & Voucher/ Collection data & $\begin{array}{l}\text { COI-5P } \\
\text { Accession } \\
\text { numbers }\end{array}$ & $\begin{array}{l}\text { rbcL } \\
\text { Accession } \\
\text { numbers }\end{array}$ \\
\hline $\begin{array}{l}\text { Laurencia alfredensis C.Francis, } \\
\text { J.J.Bolton, Mattio \& R.J.Anderson }\end{array}$ & $\begin{array}{l}\text { South Africa, Western Cape, Grootbank, 4.VII.2008, R. Anderson \& } \\
\text { J. Bolton }\end{array}$ & - & KY927749 \\
\hline Laurencia cf. brongniartii J.Agardh & Australia, Western Australia, Tarcoola Beach, 1993, S. Fredericq & - & EF061654 \\
\hline Laurencia cf. brongniartii & Taiwan, Makang Harbour, 11.VII.1993, S. Fredericq & - & AF465814 \\
\hline $\begin{array}{l}\text { Laurencia caduciramulosa Masuda \& } \\
\text { S.Kawaguchi }\end{array}$ & $\begin{array}{l}\text { Spain, Canary Islands, Tenerife, Punta del Hidalgo, 6.V.2008, M. Gil- } \\
\text { Rodríguez, M. Fujii, V. Cassano \& J. Díaz-Larrea }\end{array}$ & - & JF781525 \\
\hline Laurencia caduciramulosa & $\begin{array}{l}\text { United States, Florida, Key Biscayne, Crandon Park, 13.VIII.2013, } \\
\text { L. Collado-Vides, A. Duran, M. Fujii, V. Cassano \& J. Díaz-Larrea }\end{array}$ & - & KJ700867 \\
\hline Laurencia caduciramulosa & Cuba, Havana, Rincon de Guanabo, 2002, A. Areces & - & FJ904933 \\
\hline Laurencia caduciramulosa & $\begin{array}{l}\text { Brazil, Rio de Janeiro, Angra dos Reis, Praia do Velho, 19.IV.2006, V. } \\
\text { Cassano \& J.C. De-Paula }\end{array}$ & - & KJ700865 \\
\hline Laurencia cf. calliptera Kütz. & New Caledonia, Ile des Pins, 2.XII.2005, C. Payri & KX258825 & - \\
\hline Laurencia caraibica P.C.Silva & Mexico, Quintana Roo, Cancún, Isla Mujeres, 2006, A. Sentíes & - & EF658642 \\
\hline $\begin{array}{l}\text { L. catarinensis Cordeiro-Marino \& } \\
\text { M.T.Fujii }\end{array}$ & Brazil, Rio Grande do Norte, Maracajau, 24.VI.2006, M. Fujii \& I. Silva & - & \\
\hline Laurencia catarinensis & $\begin{array}{l}\text { Bermuda, St. David's I., Fort Hill Bay, Cooper's Island, 27.V.2012, } \\
\text { T. Popolizio; BDA } 1130 \text { [TRP 12-65-2] }\end{array}$ & OK209904 & OK209872 \\
\hline Laurencia catarinensis & $\begin{array}{l}\text { United States, Florida, Key West, East Dry Rocks Reef, 30.V.2013, C. } \\
\text { Schneider, C. Lane \& T. Popolizio; KW } 208 \text { [CWS/CEL/TRP 13-13-16] }\end{array}$ & OK209903 & OK209873 \\
\hline Laurencia catarinensis & $\begin{array}{l}\text { US Virgin Islands, St. Croix, Fredericksted Pier, 24.XI.2013, T. Popolizio \& } \\
\text { E. Salomaki; STX } 222 \text { [TRP 13-40-5] }\end{array}$ & OK209898 & OK209874 \\
\hline Laurencia catarinensis & $\begin{array}{l}\text { Spain, Canary Islands, Lanzarote, Pechigueras, 15.I.2013, M. Gil-Rodriguez } \\
\text { \& M. Machin-Sanchez }\end{array}$ & KF492718 & - \\
\hline Laurencia catarinensis & Spain, Canary Islands, Tenerife, El Pris, 3.II.2011, M. Machin-Sanchez & - & KF492776 \\
\hline Laurencia catarinensis & $\begin{array}{l}\text { Spain, Canary Islands, Lanzarote, Arrecife, 18.X.2012, J. Martin, M. Carrillo } \\
\text { Perez }\end{array}$ & - & KF492780 \\
\hline Laurencia complanata (Suhr) Kütz. & $\begin{array}{l}\text { South Africa, KwaZulu-Natal, Salt Rock, 9.XII.2010, R. Anderson \& } \\
\text { J. Bolton }\end{array}$ & - & KY927738 \\
\hline Laurencia corymbosa J.Agardh & $\begin{array}{l}\text { South Africa, Eastern Cape, Double Mouth, 14.VII.2010, R. Anderson \& } \\
\text { J. Bolton }\end{array}$ & - & KY927728 \\
\hline Laurencia dendroidea J.Agardh & Brazil, Sao Paulo, Ubatuba, Praia do Felix, 31.VIII.2000, M. Fujii & - & AF465810 \\
\hline Laurencia dendroidea & Brazil, Rio de Janeiro, Ponta do Caioba, Angra dos Reis, 2004, V. Cassano & - & GU330223 \\
\hline Laurencia dendroidea & $\begin{array}{l}\text { Bermuda, Middle buoy, Eastern Blue Cut channel, north of Daniel's Head, } \\
\text { Somerset Is., 20.VIII.2010, C. Schneider, C. Lane \& T. Popolizio; BDA } \\
0137 \text { [CWS/CEL 10-12-38] }\end{array}$ & OK209900 & OK209876 \\
\hline Laurencia dendroidea & $\begin{array}{l}\text { United States, Florida, Key West, Fort Zachary Taylor, 28.V.2013, } \\
\text { C. Schneider, C. Lane, D. McDevit \& T. Popolizio; KW } 064 \text { [CWS/CEL/ } \\
\text { TRP 13-7-2] }\end{array}$ & OK209901 & OK209875 \\
\hline Laurencia dendroidea & $\begin{array}{l}\text { US Virgin Islands, St. Croix, Salt River Bay, 21.XI.2013, C. Lane, } \\
\text { T. Popolizio \& E. Salomaki; STX } 111 \text { [CEL/TRP 13-30-2] }\end{array}$ & OK209899 & OK209877 \\
\hline Laurencia dendroidea & Hawaii, Molokai, 10.II.2007, A. Sherwood (ARS02692) & GU223887 & - \\
\hline Laurencia dendroidea & stralia, Western Australia, Little Turtle, 15.V.2008, J. Huisman & MT822859 & - \\
\hline Laurencia dendroidea & $\begin{array}{l}\text { Australia, New South Wales, Batehaven, Batemans Bay, Observation Point, } \\
\text { 30.V.2005, Y. Metti }\end{array}$ & MT822855 & - \\
\hline Laurencia dendroidea & Australia, New South Wales, Arrawara Headland, 28.VII.2004, Y. Metti & MT822858 & - \\
\hline Laurencia dendroidea & $\begin{array}{l}\text { Australia, Norfolk Island, Little Organ off Captain Cook Memorial, } \\
\text { 18.III.2005, Y. Metti }\end{array}$ & MT822857 & - \\
\hline Laurencia dendroidea & $\begin{array}{l}\text { Australia, New South Wales, Batehaven, Batemans Bay, Observation Point, } \\
\text { 25.X.2005, Y. Metti \& A. Millar }\end{array}$ & MT822856 & - \\
\hline Laurencia dendroidea & $\begin{array}{l}\text { Spain, Canary Islands, Lanzarote, Pechigueras, 15.I.2013, M. Gil-Rodriguez } \\
\text { \& M. Manchin-Sanchez }\end{array}$ & KF492728 & - \\
\hline \multirow[t]{2}{*}{ Laurencia dendroidea } & $\begin{array}{l}\text { Spain, Canary Islands, La Gomera, Punta de La Dama, 21.IX.2009, } \\
\text { E. Aylagas \& M. Manchin-Sanchez }\end{array}$ & KF492725 & - \\
\hline & $\begin{array}{l}\text { Spain, Canary Islands, Tenerife, Puerto Cruz, 13.VII.2006, M. Gil- } \\
\text { Rodriguez, M. Fujii \& M. Manchin-Sanchez }\end{array}$ & - & EF686000 \\
\hline Laurencia dendroidea & Venezuela, Falcon, Playa Buchuacos, 6.X.2012, G. Garcia-Soto & МH388711 & - \\
\hline $\begin{array}{l}\text { Laurencia dichotoma C.Francis, } \\
\text { J.J.Bolton, Mattio \& R.J.Anderson }\end{array}$ & $\begin{array}{l}\text { South Africa, KwaZulu-Natal, Sodwana Bay, Jesser Point, 22.III.2011, J. } \\
\text { Bolton, R. Anderson \& C. Francis }\end{array}$ & - & KY927786 \\
\hline $\begin{array}{l}\text { Laurencia digitata C.Francis, } \\
\text { J.J.Bolton, Mattio \& R.J.Anderson }\end{array}$ & $\begin{array}{l}\text { South Africa, Western Cape, De Hoop, East of Koppie Alleen, 18.II.2011, } \\
\text { C. Francis, R. Anderson \& J. Bolton }\end{array}$ & - & KY927779 \\
\hline Laurencia filiformis (C.Agardh) Mont. & $\begin{array}{l}\text { Australia, Western Australia, Tarcoola Beach, 21.IX.1995, M. Hommersand } \\
\text { \& F. Hommersand }\end{array}$ & - & MH704449 \\
\hline Laurencia flexuosa Kütz. & South Africa, S. KwaZulu-Natal, Palm Beach, 7.II.2001, S. Fredericq & - & AF465815 \\
\hline Laurencia glomerata Kütz. & $\begin{array}{l}\text { South Africa, Western Cape, Mauritz Bay, 2.III.2011, M. Rothmann, C. } \\
\text { Boothroyd \& F. Kemp }\end{array}$ & - & KY927793 \\
\hline Laurencia intricata J.V.Lamour. & Cuba, Ciego de Avila, Cayo Coco, 25.IX.2005, M. Fujii & - & GU330238 \\
\hline
\end{tabular}




\begin{tabular}{|c|c|c|c|}
\hline Taxa & Voucher/ Collection data & $\begin{array}{l}\text { COl-5P } \\
\text { Accession } \\
\text { numbers }\end{array}$ & $\begin{array}{l}\text { rbcL } \\
\text { Accession } \\
\text { numbers }\end{array}$ \\
\hline Laurencia intricata & $\begin{array}{l}\text { Bermuda, Bermuda I., Fairyland Creek, 25.VIII.2010, C. Schneider, C. Lane } \\
\text { \& T. Popolizio; BDA } 0483 \text { [CWS/CEL 10-32-5] }\end{array}$ & OK209897 & OK209879 \\
\hline Laurencia intricata & $\begin{array}{l}\text { United States, Florida, Key West, White Street Pier, 29.V.2013, C. } \\
\text { Schneider, C. Lane, D. McDevit \& T. Popolizio; KW } 131 \text { [CWS/CEL/TRP } \\
\text { 13-9-23] }\end{array}$ & OK209906 & OK209878 \\
\hline Laurencia intricata & $\begin{array}{l}\text { United States, Florida, Key Biscayne, Crandon Park, 13.VIII.2013, } \\
\text { L. Collado-Vides, V. Cassano \& M. Fujii }\end{array}$ & - & MG004181 \\
\hline Laurencia intricata & $\begin{array}{l}\text { US Virgin Islands, St. Croix, Deep Wrecks, 19.XI.2013, C. Lane, } \\
\text { T. Popolizio \& E. Salomaki; STX } 010 \text { [CEL/TRP 13-23-9] }\end{array}$ & - & OK209882 \\
\hline Laurencia intricata & $\begin{array}{l}\text { Mexico, Quintana Roo, Playa del Carmen, 2002, J. Díaz-Larrea \& } \\
\text { A. Sentíes }\end{array}$ & - & GQ149489 \\
\hline Laurencia intricata & $\begin{array}{l}\text { Mexico, Quintana Roo, Puerto Morelos, Ojo Agua, 2004, J. Diaz-Larrea \& } \\
\text { A. Sentíes }\end{array}$ & - & EF658644 \\
\hline $\begin{array}{l}\text { Laurencia karachiana Bibi, V.Cassano } \\
\text { \& Rasheed }\end{array}$ & Pakistan, Karachi, Buleji, 13.VIII.2018, R. Bibi & MK796229 & MK796228 \\
\hline Laurencia cf. kuetzingii A.Millar & New Caledonia, Loyalty Is., Ouvea, 31.III.2005, C. Payri & - & FJ785322 \\
\hline $\begin{array}{l}\text { Laurencia laurahuertana Mateo-Cid, } \\
\text { Mendoza-Gonzalez, Sentíes \& Díaz- } \\
\text { Larrea }\end{array}$ & $\begin{array}{l}\text { Mexico, Quintana Roo, Punta Herrero, 2012, A. Mendoza-Gonzalez \& } \\
\text { L. Mateo-Cid }\end{array}$ & - & KF279401 \\
\hline $\begin{array}{l}\text { Laurencia longiramea Cassano, } \\
\text { G.N.Santos, J.M.C.Nunes, } \\
\text { M.C.Oliveira \& M.T.Fujii }\end{array}$ & $\begin{array}{l}\text { Brazil, Bahia, Maraú, Barra Grande, Praia de Três Coqueiros, 28.IX.2015, } \\
\text { G. Santos, E. Pestana \& J. Nunes }\end{array}$ & - & MH704450 \\
\hline Laurencia longiramea & Brazil, Espirito Santo, Anchieta, Ilhote de Ubu, 30.VI.2007, E. Stein & $\mathrm{MH} 704454$ & - \\
\hline $\begin{array}{l}\text { Laurencia majuscula (Harv.) } \\
\text { A.H.S.Lucas }\end{array}$ & Oman, Dhofar, IX.2001, M. Wynne & KX258827 & - \\
\hline Laurencia cf. majuscula & New Caledonia, Ile des Pins, 2.XII.2005, C. Payri & - & FJ785312 \\
\hline Laurencia cf. mariannensis Yamada & New Caledonia, Lagon Sud-Ouest, Ilot Laregnere, 11.VII.2003, C. Payri & - & FJ785313 \\
\hline Laurencia mcdermidiae I.A.Abbott & United States, Hawaii, Oahu, 8.IV.2007 & GU223878 & - \\
\hline Laurencia mcdermidiae & United States, Hawaii, A. Sherwood (ARS03611) & HQ422883 & - \\
\hline Laurencia mcdermidiae & United States, Hawaii, A. Sherwood (ARS00702) & HQ422627 & - \\
\hline Laurencia microcladia Kütz. & $\begin{array}{l}\text { Bermuda, south shore Bermuda I., Capt. Williams' Bay, 15.I.2012, } \\
\text { C. Schneider, C. Lane \& T. Popolizio; BDA } 0523 \text { [CWS/CEL/TRP 12-2-2] }\end{array}$ & OK209905 & OK209880 \\
\hline Laurencia microcladia & $\begin{array}{l}\text { US Virgin Islands, St. Croix, Turtle Deli Beach, 20.XI.2013, C. Lane, } \\
\text { T. Popolizio \& E. Salomaki; STX } 079 \text { [CEL/TRP 13-26-2] }\end{array}$ & OK209896 & OK209881 \\
\hline $\begin{array}{l}\text { Laurencia multiclavata C.Francis, } \\
\text { J.J.Bolton, Mattio \& R.J.Anderson }\end{array}$ & $\begin{array}{l}\text { South Africa, KwaZulu-Natal, Sodwana Bay, Jesser Point, 22.III.2011, } \\
\text { J. Bolton, R. Anderson \& C. Francis }\end{array}$ & - & KY927789 \\
\hline $\begin{array}{l}\text { Laurencia mutueae Sentíes, Cassano } \\
\text { \& Dreckmann }\end{array}$ & $\begin{array}{l}\text { Mexico, Acapulco, Guerrero, Isla la Roqueta, 7.VI.2017, A. Sentíes \& } \\
\text { K. Dreckmann }\end{array}$ & MK182534 & MK159179 \\
\hline Laurencia natalensis Kylin & South Africa, S. KwaZulu-Natal, Palm Beach, 7.II.2001, S. Fredericq & - & AF465816 \\
\hline Laurencia nidifica J.Agardh & United States, Hawaii, Oahu, 20.V.2007, A. Sherwood (ARS02581) & GU223888 & - \\
\hline Laurencia nidifica & United States, Hawaii, A. Sherwood (ARS00704) & HQ422750 & - \\
\hline Laurencia nidifica & United States, Hawaii, A. Sherwood (ARS02526) & HQ423054 & - \\
\hline Laurencia nidifica & United States, Hawaii, A. Sherwood (ARS02485) & HQ423048 & - \\
\hline Laurencia nidifica & United States, Hawaii, A. Sherwood (ARS00687) & HQ422753 & - \\
\hline Laurencia cf. nidifica & New Caledonia, Ile des Pins, 30.XI.2005, C. Payri & - & FJ785315 \\
\hline Laurencia nipponica Yamada & Japan, Hokkaido, Muroran, 5.VI.2003 & GU223875 & - \\
\hline Laurencia nipponica & Japan, Hokkaido, Kinaoshi, 10.V.2008 & GU223876 & - \\
\hline Laurencia obtusa (Huds.) J.V.Lamour. & Ireland, County Donegal, Fanad Head, 6.VII.1998, C. Maggs & - & AF281881 \\
\hline Laurencia obtusa & $\begin{array}{l}\text { France, Languedoc-Roussillon, Pyrenees-Orientales, Cap Beart, Banyuls- } \\
\text { sur-Mer, 11.VII.2007, L. Bittner }\end{array}$ & KX258828 & - \\
\hline Laurencia oliveirana Yonesh. & $\begin{array}{l}\text { Brazil, Rio de Janeiro, Arraial do Cabo, Ponta da Cabeca, 7.VII.2008, } \\
\text { V. Cassano \& J. De-Paula }\end{array}$ & - & JF810352 \\
\hline Laurencia pacifica Kylin & $\begin{array}{l}\text { United States, California, Moss Beach, Central Beach, 17.II.1992, } \\
\text { S. Fredericq }\end{array}$ & - & AY588411 \\
\hline Laurencia pacifica & $\begin{array}{l}\text { United States, California, Pebble Beach, Stillwater Cove, 20.V.2010, } \\
\text { B. Clarkston, K. Hind \& S. Toews (GWS022101) }\end{array}$ & KM254466 & - \\
\hline Laurencia pacifica & $\begin{array}{l}\text { United States, California, Pebble Beach, Stillwater Cove, 20.V.2010, } \\
\text { B. Clarkston, K. Hind \& S. Toews (GWS022084) }\end{array}$ & HQ544189 & - \\
\hline Laurencia pumila (Grunow) Papenf. & $\begin{array}{l}\text { South Africa, KwaZulu-Natal, Sodwana Bay, Jesser Point, 9.VI.2010, } \\
\text { R. Anderson \& J. Bolton }\end{array}$ & - & KY927730 \\
\hline Laurencia pyramidalis Bory ex Kütz. & France, Brittany, Roscoff, 5.XII.2002, F. Rousseau & - & FJ785316 \\
\hline Laurencia pyramidalis & $\begin{array}{l}\text { Portugal, Azores, Sao Miguel, Mosteiros, 27.VI.2011, M. Fujii, A. Prestes, A. } \\
\text { Pacheco \& M. Machin-Sanchez }\end{array}$ & KF492751 & - \\
\hline
\end{tabular}




\begin{tabular}{|c|c|c|c|}
\hline Taxa & Voucher/ Collection data & $\begin{array}{l}\text { COI-5P } \\
\text { Accession } \\
\text { numbers }\end{array}$ & $\begin{array}{l}\text { rbcL } \\
\text { Accession } \\
\text { numbers }\end{array}$ \\
\hline Laurencia pyramidalis & $\begin{array}{l}\text { Portugal, Madeira, Seixal, Praia da Laje, 7.VII.2011, E. Nogueira, V. } \\
\text { Cassano \& A. Sentíes }\end{array}$ & KF492733 & - \\
\hline Laurencia pyramidalis & $\begin{array}{l}\text { Spain, Canary Islands, Fuerteventura, Garcey, 10.IX.2012, M. Machin- } \\
\text { Sanchez }\end{array}$ & KF492756 & - \\
\hline Laurencia pyramidalis & $\begin{array}{l}\text { Spain, Canary Islands, Tenerife, Puerto de La Cruz, 20.V.2011, M. Gil- } \\
\text { Rodriguez \& M. Machin-Sanchez }\end{array}$ & KF492746 & - \\
\hline Laurencia pyramidalis & $\begin{array}{l}\text { Spain, Canary Islands, Lanzarote, Pechigueras, 11.IV.2012, M. Gil- } \\
\text { Rodriguez \& M. Manchin-Sanchez }\end{array}$ & - & KF492791 \\
\hline Laurencia saitoi Perest. & $\begin{array}{l}\text { United States, California, Monterey, McAbee Beach, 21.V.2010, B. } \\
\text { Clarkston, K. Hind \& S. Toews (GWS022101) }\end{array}$ & HQ544222 & - \\
\hline $\begin{array}{l}\text { Laurencia stegengae C.Francis, } \\
\text { J.J.Bolton, Mattio \& R.J.Anderson }\end{array}$ & $\begin{array}{l}\text { South Africa, Western Cape, Buffel's Bay, 17.IX.2008, R. Anderson \& } \\
\text { J. Bolton }\end{array}$ & - & KY927761 \\
\hline Laurencia venusta Yamada & Australia, Lord Howe Island, Sylphs Hole, 26.X.2005, Y. Metti \& A. Millar & - & KY120345 \\
\hline Laurencia venusta & $\begin{array}{l}\text { Mexico, Quintana Roo, Puerto Morelos, Punta Brava, 18.IV.2004, J. Diaz- } \\
\text { Larrea \& A. Sentíes }\end{array}$ & - & EF061655 \\
\hline $\begin{array}{l}\text { Laurencia viridis Gil-Rodríguez \& } \\
\text { Haroun }\end{array}$ & $\begin{array}{l}\text { Spain, Canary Islands, Tenerife, Punta del Hidalgo, Roca Negra, 6.X.2005, } \\
\text { M. Gil-Rodríguez }\end{array}$ & - & EF685999 \\
\hline Laurencia viridis & $\begin{array}{l}\text { Spain, Canary Islands, Tenerife, Punta del Hidalgo, 13.I.2012, M. Gil- } \\
\text { Rodriguez \& M. Machin-Sanchez }\end{array}$ & KF492758 & - \\
\hline Laurencia viridis & $\begin{array}{l}\text { Portugal, Azores, Santa Maria, Emisores, 2.VII.2011, E. Nogueira, } \\
\text { V. Cassano \& A. Sentíes }\end{array}$ & KF492759 & - \\
\hline Laurencia viridis & $\begin{array}{l}\text { Portugal, Azores, Santa Maria, Boca de Ribeira Seca, 2.VII.2011, M. Fujii, } \\
\text { A. Neto, J. Pombo, M. Machin-Sanchez }\end{array}$ & KF492760 & - \\
\hline Laurencia viridis & $\begin{array}{l}\text { Portugal, Azores, Santa Maria, Boca de Ribeira Seca, 2.VII.2011, M. Fujii, } \\
\text { A. Neto, J. Pombo, M. Machin-Sanchez }\end{array}$ & - & KF492794 \\
\hline Laurencia yamadana M.Howe & United States, Hawaii, Maui, Kihei, 5.IV.2006, A. Carlile & - & GQ252550 \\
\hline Laurencia sp. 1 & New Caledonia, Loyalty Is., Maré, 19.III.2005, C. Payri & KX258819 & - \\
\hline Laurencia sp. 2 & $\begin{array}{l}\text { New Caledonia, Lagon Sud-Ouest, llot Larégnère, 31.I.2008, J. Martin- } \\
\text { Lescanne }\end{array}$ & KX258824 & - \\
\hline Laurencia sp. & Oman, Dhofar, IX.2001, M. Wynne & - & KX146184 \\
\hline Laurencia sp. & Sri Lanka, Odayapiti lagoon, 8.XI.2006, E. Coppejans & KX258818 & KX146176 \\
\hline $\begin{array}{l}\text { Laurenciella marilzae Gil-Rodríguez, } \\
\text { Sentíes, Díaz-Larrea, Cassano \& } \\
\text { M.T. Fujii }\end{array}$ & $\begin{array}{l}\text { Spain, Canary Islands, Tenerife, Punta del Hidalgo, 12.VII.2006, M. Gil- } \\
\text { Rodríguez }\end{array}$ & - & EF686002 \\
\hline Laurenciella marilzae & $\begin{array}{l}\text { Spain, Canary Islands, Lanzarote, Pechigueras, 15.I.2013, M. Gil- } \\
\text { Rodríguez \& M. Machin-Sanchez }\end{array}$ & KF492762 & - \\
\hline Laurenciella marilzae & $\begin{array}{l}\text { Portugal, Azores, Sao Miguel, Cerco da Caloura-Baia, 26.VI.2011, } \\
\text { E. Nogueira, V. Cassano \& A. Sentíes }\end{array}$ & KF492765 & - \\
\hline Laurenciella marilzae & $\begin{array}{l}\text { Spain, Canary Islands, Tenerife, Punta del Hidalgo, 13.I.2012, M. Gil- } \\
\text { Rodríguez \& M. Machin-Sanchez }\end{array}$ & KF492769 & - \\
\hline Laurenciella marilzae & Italy, Palermo, Ustica Island, 4.IX.2017, D. Serio, G. Furnari \& Y. Metti & - & MT822845 \\
\hline Laurenciella marilzae & Italy, Sicily, Brucoli, Siracusa, 18.VII.2017, D. Serio, G. Furnari \& Y. Metti & - & MT822841 \\
\hline $\begin{array}{l}\text { Laurenciella mayaimii Collado-Vides, } \\
\text { Cassano \& M.T.Fujii }\end{array}$ & $\begin{array}{l}\text { United States, Florida, Key Largo, 14.VIII.2013, L. Collado-Vides, } \\
\text { V. Cassano \& M. Fujii }\end{array}$ & MG004178 & MG004183 \\
\hline Laurenciella mayaimii & $\begin{array}{l}\text { United States, Florida, Biscayne Bay, 12.VIII.2013, L. Collado-Vides, } \\
\text { V. Cassano \& M. Fujii }\end{array}$ & MG004176 & - \\
\hline $\begin{array}{l}\text { Laurenciella namii Popolizio, } \\
\text { C.W.Schneid. \& C.E.Lane sp. nov. }\end{array}$ & $\begin{array}{l}\text { Bermuda, north shore Bermuda I., Spanish Point Park, 25.VIII.2010, } \\
\text { C. Schneider, C. Lane \& T. Popolizio; BDA } 0502 \text { [CWS/CEL 10-33-13] }\end{array}$ & OK209886 & OK209870 \\
\hline Laurenciella namii sp. nov. & $\begin{array}{l}\text { Bermuda, north shore Bermuda I., Spanish Point Park, 18.I.2012, C. } \\
\text { Schneider, C. Lane \& T. Popolizio; Holotype: BDA } 0597 \text { [CWS/CEL 12-11-2] }\end{array}$ & OK209887 & - \\
\hline Laurenciella namii sp. nov. & $\begin{array}{l}\text { United States, Florida, Key West, White Street Pier, 29.V.2013, } \\
\text { C. Schneider, C. Lane, D. McDevit \& T. Popolizio; KW } 109 \text { [CWS/CEL/ } \\
\text { TRP 13-9-5] }\end{array}$ & OK209907 & OK209871 \\
\hline Laurenciella namii sp. nov. & $\begin{array}{l}\text { United States, Florida, Key Biscayne, Crandon Park, 12.VIII.2013, } \\
\text { L. Collado-Vides, V. Cassano \& M. Fujii }\end{array}$ & MG004179 & MG004184 \\
\hline Laurenciella sp. 2Brazil & Brazil, Espirito Santo, Anchieta, Ilhote de Ubu, 30.VI.2007, E. Stein & - & 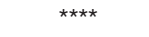 \\
\hline Laurenciella sp. 3Brazil & Brazil, Sao Paulo, Ilha Vitoria, 19.V.2008, M. Fujii & - & $\star \star \star \star ~$ \\
\hline Laurenciella sp. 1Bda & $\begin{array}{l}\text { Bermuda, Gibbet I., mouth of Flatts Inlet, 2.II.2012, T. Popolizio; BDA } 0806 \\
\text { [TRP 12-29-16] }\end{array}$ & OK209885 & OK209869 \\
\hline $\begin{array}{l}\text { Ohelopapa flexilis (Setch.) F.Rousseau, } \\
\text { Martin-Lescanne, Payri \& L.Le Gall }\end{array}$ & , French Polynesia, Tahiti, Tahara Reef, 24.III.2007, A. Alpham & KX258830 & KX146187 \\
\hline $\begin{array}{l}\text { Osmundea blinksii (Hollenb. \& } \\
\text { I.A.Abbott) K.W.Nam }\end{array}$ & $\begin{array}{l}\text { United States, California, San Mateo County, Ano Nuevo, Greyhound Rock, } \\
\text { 17.VII.1996, M. Hommersand }\end{array}$ & - & AY172575 \\
\hline $\begin{array}{l}\text { Osmundea caspica (Zinova \& } \\
\text { Zaberzhinskaya) Maggs \& } \\
\text { L.M.Mclvor }\end{array}$ & Azerbaijan, Sangachal Bay, 1.IX.2003 & - & KX146188 \\
\hline
\end{tabular}




\begin{tabular}{|c|c|c|c|}
\hline Taxa & Voucher/ Collection data & $\begin{array}{l}\text { COI-5P } \\
\text { Accession } \\
\text { numbers }\end{array}$ & $\begin{array}{c}\text { rbcL } \\
\text { Accession } \\
\text { numbers }\end{array}$ \\
\hline Osmundea hybrida (DC.) K.W.Nam & France, Brittany, St. Lunaire, 20.III.1999, F. Rousseau & - & FJ785317 \\
\hline Osmundea hybrida & France, Brittany, Roscoff, Finistere,12.V.2002, F. Rousseau & KX258831 & - \\
\hline Osmundea hybrida & Ireland, County Donegal, Fanad Head, 7.XI.1999, C. Maggs & - & AF281878 \\
\hline $\begin{array}{l}\text { Osmundea oederi (Gunnerus) } \\
\text { G.Furnari }\end{array}$ & Ireland, Donegal County, St John's Point, 12.X.1999, C. Maggs & - & AF281880 \\
\hline $\begin{array}{l}\text { Osmundea osmunda (S.G.Gmel.) } \\
\text { K.W.Nam }\end{array}$ & Ireland, County Donegal, St John’s Point, 12.X.1999, C. Maggs & - & AF281877 \\
\hline Osmundea osmunda & France, Brittany, Le Loup, 19.V.2011, L. Couceiro \& M. Robuchon & KJ960875 & - \\
\hline Osmundea osmunda & France, Brittany, Roscoff, 5.XII.2002, F. Rousseau & - & FJ785318 \\
\hline Osmundea pinnatifida (Huds.) Stackh. & Ireland, Galway, Black Head, H.-G. Choi \& M. Guiry & - & JX828140 \\
\hline Osmundea pinnatifida . & Ireland, Co. Donegal, St. John's Point, 12.X.1999, C. Maggs & - & AF281875 \\
\hline Osmundea pinnatifida . & Ireland, Co. Donegal, St. John’s Point, 12.X.1999, C. Maggs & - & AF281876 \\
\hline Osmundea pinnatifida & France, Brittany, Le Loup, 8.III.2012, L. Couceiro \& M. Robuchon & KJ960886 & - \\
\hline Osmundea pinnatifida & $\begin{array}{l}\text { Spain, Canary Islands, Tenerife, Puerto de la Cruz, San Telmo, 7.X.2005, M. } \\
\text { Gil-Rodriguez }\end{array}$ & - & EF686005 \\
\hline $\begin{array}{l}\text { Osmundea sanctarum M.T.Fujii \& } \\
\text { R.Rocha-Jorge }\end{array}$ & $\begin{array}{l}\text { Brazil, Sao Paulo, Parcel do Sul, Laje de Santos Marine State Park, } \\
\text { 19.IV.2012, R. Rocha-Jorge, M. Barros-Barreto, I. Silva \& M. Fujii }\end{array}$ & - & KC012600 \\
\hline $\begin{array}{l}\text { Osmundea sinicola (Setch. \& } \\
\text { N.L.Gardner) K.W.Nam }\end{array}$ & $\begin{array}{l}\text { United States, California, Orange County, Crescent Beach, 28.V.2002, S. } \\
\text { Murray }\end{array}$ & - & AY588407 \\
\hline $\begin{array}{l}\text { Osmundea spectabilis (Postels \& } \\
\text { Rupr.) K.W.Nam }\end{array}$ & Mexico, Baja California, Punta Santo Thomas, 2.VII.1996, M. Hommersand & - & AY172574 \\
\hline Osmundea spectabilis & $\begin{array}{l}\text { United States, California, Pacific Grove, Bird Rock, 22.V.2010, B. Clarkston, } \\
\text { K. Hind \& S. Toews (GWS022314) }\end{array}$ & KM254469 & - \\
\hline Osmundea spectabilis & $\begin{array}{l}\text { United States, California, Monterey, McAbee Beach, 21.V.2010, B. } \\
\text { Clarkston, K. Hind \& S. Toews (GWS022243) }\end{array}$ & KM254320 & - \\
\hline Osmundea spectabilis & $\begin{array}{l}\text { United States, California, Pescadero, Pigeon Point Lighthouse, 15.V.2010, } \\
\text { B. Clarkston \& K. Hind (GWS021292) }\end{array}$ & KM254866 & - \\
\hline Osmundea spectabilis & $\begin{array}{l}\text { United States, California, Carmel-by-the-Sea, Soberanes Point, 17.V.2010, } \\
\text { B. Clarkston, K. Hind \& S. Toews (GWS021719) }\end{array}$ & KM254508 & - \\
\hline Osmundea spectabilis & $\begin{array}{l}\text { United States, California, Carmel-by-the-Sea, Soberanes Point, 17.V.2010, } \\
\text { B. Clarkston, K. Hind \& S. Toews (GWS021704) }\end{array}$ & KM254561 & - \\
\hline Osmundea spectabilis & $\begin{array}{l}\text { United States, California, San Diego Co., Point Loma, College of the } \\
\text { Nazarenes, } 7 \text { Jul.1996, M. Hommersand }\end{array}$ & - & AY172572 \\
\hline Osmundea spectabilis & $\begin{array}{l}\text { United States, Washington, Partridge Point, Whidbey Island, 12.VII.2011, } \\
\text { A. Savoie \& K. Hind }\end{array}$ & KU564384 & - \\
\hline Osmundea spectabilis & $\begin{array}{l}\text { United States, Washington, Clallam Co., 28.VIII.2012, A. Carlile \& J. } \\
\text { Waaland }\end{array}$ & - & GQ252562 \\
\hline Osmundea spectabilis & United States, Alaska, Sitka, 22.VI.2005, A. Carlile \& J. Waaland & - & GQ252493 \\
\hline $\begin{array}{l}\text { Osmundea splendens (Hollenb.) } \\
\text { K.W.Nam }\end{array}$ & Mexico, Baja California, Bahia Colnett, 2.VII.1996, M. Hommersand & - & AY172576 \\
\hline Osmundea splendens & $\begin{array}{l}\text { United States, California, Santa Cruz, Four Mile, 19.V.2010, B. Clarkston, } \\
\text { K. Hind \& S. Toews (GWS021992, -998) }\end{array}$ & HQ919290 & KU564461 \\
\hline Osmundea splendens & $\begin{array}{l}\text { United States, California, Santa Cruz, Four Mile, 19.V.2010, B. Clarkston, } \\
\text { K. Hind \& S. Toews (GWS021984) }\end{array}$ & KM254322 & - \\
\hline Osmundea splendens & United States, California, Newport, Crystal Grove, 10.XII.2012, K. Miller & - & MH911631 \\
\hline $\begin{array}{l}\text { Osmundea truncata (Kutz.) K.W.Nam } \\
\text { \& Maggs }\end{array}$ & $\begin{array}{l}\text { Spain, Canary Islands, Tenerife, La Barranquera, 5.V.2008, M. Gil- } \\
\text { Rodríguez, M. Fujii, V. Cassano \& J. Díaz-Larrea }\end{array}$ & - & JF781523 \\
\hline Osmundea sp. & Spain, Canary Islands, Gran Canarias, Punta Caldar, 2008 & - & JF781519 \\
\hline $\begin{array}{l}\text { Palisada corallopsis (Mont.) Sentíes, } \\
\text { M.T.Fujii \& Díaz-Larrea }\end{array}$ & $\begin{array}{l}\text { Mexico, Quintana Roo, Cancun, Chaac-Mol Beach, 21.VIII.2005, J. Díaz- } \\
\text { Larrea \& A. Sentíes }\end{array}$ & - & EF061646 \\
\hline Palisada corallopsis & $\begin{array}{l}\text { Bermuda, north shore Bermuda I., Bailey's Reef, 17.VIII.2012, C. Schneider, } \\
\text { C. Lane \& T. Popolizio; BDA } 1336 \text { [CWS/CEL/TRP 12-94-2] }\end{array}$ & & OK209865 \\
\hline $\begin{array}{l}\text { Palisada cervicornis (Harv.) Collado- } \\
\text { Vides, Cassano \& M.T.Fujii }\end{array}$ & United States, Florida, Key Largo, Pickles Reef, 14.VIII.2014, A. Duran & - & MG030375 \\
\hline Palisada cervicornis & $\begin{array}{l}\text { Bermuda, Brackish Pond Flats, inner reef, north shore (3-4 m), 17.I.2012, } \\
\text { C. Schneider, C. Lane \& T. Popolizio; BDA } 0559 \text { [CWS/CEL/TRP 12-8-16] }\end{array}$ & OK209888 & OK209863 \\
\hline $\begin{array}{l}\text { Palisada crustiformans (McDermid) } \\
\text { A.R.Sherwood, A.Kurihara \& } \\
\text { K.W.Nam }\end{array}$ & United States, Hawaii, Oahu, Makapuu, 26.V.2007, A. Kurihara & - & KX146196 \\
\hline $\begin{array}{l}\text { Palisada flagellifera (J.Agardh) } \\
\text { K.W.Nam }\end{array}$ & $\begin{array}{l}\text { Spain, Canary Islands, Tenerife, Playa Paraiso, 12.VII.2006, M. Gil- } \\
\text { Rodríguez, M. Fujii \& A. Sentíes }\end{array}$ & - & EF685998 \\
\hline Palisada flagellifera & $\begin{array}{l}\text { Spain, Canary Islands, Tenerife, Punta del Hidalgo, 13.I.2012, M. Gil- } \\
\text { Rodriguez \& M. Machin-Sanchez }\end{array}$ & KF492772 & - \\
\hline Palisada flagellifera & $\begin{array}{l}\text { Bermuda, SW of North Rock BAMZ "pink sand" collecting site, 16.XI.2012, } \\
\text { T. Popolizio; BDA } 1665 \text { [TRP 12-151-8] }\end{array}$ & OK209892 & OK209866 \\
\hline
\end{tabular}




\begin{tabular}{|c|c|c|c|}
\hline Taxa & Voucher/ Collection data & $\begin{array}{l}\text { COI-5P } \\
\text { Accession } \\
\text { numbers }\end{array}$ & $\begin{array}{l}\text { rbcL } \\
\text { Accession } \\
\text { numbers }\end{array}$ \\
\hline $\begin{array}{l}\text { Palisada furcata (Cordeiro-Marino \& } \\
\text { M.T.Fujii) Cassano \& M.T.Fujii }\end{array}$ & Brazil, Praia de Tambau, Paraiba, 24.II.2004, M. Fujii & - & GU330226 \\
\hline $\begin{array}{l}\text { Palisada parvipapillata (C.K.Tseng) } \\
\text { K.W.Nam }\end{array}$ & New Caledonia, l'îlot Bayes, 1.I.2001, C. Payri & KX258839 & KX146194 \\
\hline Palisada parvipapillata & United States, Hawaii, Oahu, Hauula Beach Park, 18.IX.2007, A. Kurihara & GU223895 & - \\
\hline $\begin{array}{l}\text { Palisada patentiramea (Mont.) } \\
\text { Cassano, Sentíes, Gil-Rodríguez \& } \\
\text { M.T.Fujii }\end{array}$ & Philippines, A. Lluisma & - & AF489862 \\
\hline Palisada perforata (Bory) K.W.Nam & $\begin{array}{l}\text { Spain, Canary Islands, Tenerife, Puerto de La Cruz, San Telmo, 14.VII.2006, } \\
\text { M. Gil-Rodríguez, M. Fujii \& A. Sentíes }\end{array}$ & - & EU256329 \\
\hline Palisada perforata & $\begin{array}{l}\text { Bermuda, Bermuda I., Gravelly Bay, 22.VIII.2012, C. Schneider, C. Lane \& } \\
\text { T. Popolizio; BDA } 0314 \text { [CWS/CEL 10-21-4] }\end{array}$ & OK209891 & OK209867 \\
\hline Palisada perforata & $\begin{array}{l}\text { United States, Florida, Key West, Low Key Channel, 27.V.2013, } \\
\text { C. Schneider, C. Lane, D. McDevit \& T. Popolizio; KW } 016 \text { [CWS/CEL/ } \\
\text { TRP 13-6-15] }\end{array}$ & OK209883 & OK209868 \\
\hline Palisada perforata & $\begin{array}{l}\text { Spain, Canary Islands, Tenerife, Punta del Hidalgo, 13.I.2012, M. Gil- } \\
\text { Rodriguez \& M. Machin-Sanchez }\end{array}$ & KF492773 & - \\
\hline Palisada perforata & Venezuela, Falcon, Playa Buchuacos, 6.X.2012, G. Garcia-Soto & MH388710 & - \\
\hline Palisada cf. robusta K.W.Nam & New Caledonia, Lifu, 23.III.2005, C. Payri & - & FJ785321 \\
\hline Palisada sp. 1Fla & $\begin{array}{l}\text { United States, Florida, Cudjoe Key, Summerland Bridge, 31.V.2013, C. } \\
\text { Schneider, C. Lane, D. McDevit \& T. Popolizio; KW } 234 \text { [CWS/CEL/TRP } \\
\text { 13-14-17] }\end{array}$ & OK209889 & OK209864 \\
\hline Palisada sp. 1 & New Caledonia, Lifou, 23.III.2005, C. Payri & KX258835 & - \\
\hline Palisada sp. 2 & New Caledonia, Nouméa, 4.IV.2008, J. Martin-Lescanne & KX258837 & - \\
\hline Palisada sp. & $\begin{array}{l}\text { South Africa, KwaZulu-Natal, Sodwana Bay, Jesser Point, 9.IX.2010, J. } \\
\text { Bolton, R. Anderson \& C. Francis }\end{array}$ & - & KY927798 \\
\hline $\begin{array}{l}\text { Yuzurua iridescens (M.J.Wynne \& } \\
\text { D.L.Ballant.) Sentíes, M.J.Wynne, } \\
\text { Cassano, Gil-Rodríguez \& M.T.Fujii }\end{array}$ & $\begin{array}{l}\text { Bermuda, Bermuda I., Southampton, West Whale Bay boiler reefs, } \\
\text { 18.VI.2006, C. Schneider \& C. Lane [CWS/CEL 06-4-8] }\end{array}$ & - & OK209858 \\
\hline Yuzurua iridescens & $\begin{array}{l}\text { Bermuda, Bermuda I., Southampton, West Whale Bay boiler reefs, } \\
\text { 20.I.2012, C. Schneider, C. Lane \& T. Popolizio; BDA } 0707 \text { [CWS/CEL/ } \\
\text { TRP 12-21-14] }\end{array}$ & OK209902 & - \\
\hline $\begin{array}{l}\text { Yuzurua poiteaui (J.V.Lamour.) Martin- } \\
\text { Lescanne }\end{array}$ & $\begin{array}{l}\text { Cuba, La Habana, Rincon de Guanabo, 29.VII.2005, J. Díaz-Larrea \& A. } \\
\text { Mallea }\end{array}$ & - & EF061650 \\
\hline Yuzurua poiteaui & $\begin{array}{l}\text { Bermuda, St. George's I., Ferry Reach, BIOS dock, 19.VIII.2010, C. } \\
\text { Schneider, C. Lane \& T. Popolizio; BDA } 0083 \text { [CWS/CEL 10-11-3] }\end{array}$ & OK209894 & OK209860 \\
\hline Yuzurua poiteaui & $\begin{array}{l}\text { United States, Florida, Key West, White Street Pier, 29.V.2013, } \\
\text { C. Schneider, C. Lane, D. McDevit \& T. Popolizio; KW } 141 \text { [CWS/CEL/ } \\
\text { TRP 13-9-33] }\end{array}$ & OK209895 & OK209861 \\
\hline Yuzurua sp. 1Bda & $\begin{array}{l}\text { Bermuda, Bermuda I., Southampton, West Whale Bay boiler reefs, } \\
\text { 30.V.2012, T. Popolizio; BDA } 1153 \text { [TRP 12-69-3] }\end{array}$ & OK209893 & OK209862 \\
\hline Yuzurua sp. & West Indies, Guadeloupe, 3.V.2012, Karubenthos Expedition & - & KX146198 \\
\hline
\end{tabular}


APPENDIX 2. - Collection data and GenBank accession numbers for ITS sequences generated in this study.

\begin{tabular}{|c|c|c|}
\hline Taxa & Voucher/ Collection data & GenBank ITS nos. \\
\hline \multirow[t]{6}{*}{$\begin{array}{l}\text { Laurencia catarinensis } \\
\quad \text { Cordeiro-Marino \& M.T.Fujii }\end{array}$} & $\begin{array}{l}\text { Bermuda, Tucker's Town, Frick's Beach, 19.VIII.2010, C. Schneider, C. Lane \& } \\
\text { T. Popolizio; BDA0013 [CWS/CEL 10-5-8] }\end{array}$ & OK209908 \\
\hline & $\begin{array}{l}\text { Bermuda, St. George's Island, Tobacco Bay, 21.VIII.2010, C. Schneider, C. Lane \& } \\
\text { T. Popolizio; BDA0177 [CWS/CEL 10-14-25] }\end{array}$ & OK209910 \\
\hline & $\begin{array}{l}\text { Bermuda, Gravelly Bay, 22.VIII.2010, C. Schneider, C. Lane \& T. Popolizio; BDA0318 } \\
\text { [CWS/CEL 10-21-7] }\end{array}$ & OK209909 \\
\hline & $\begin{array}{l}\text { Bermuda, north shore Bermuda I., Spanish Point Park, 25.VIII.2010, C. Schneider, } \\
\text { C. Lane \& T. Popolizio; BDA0507 [CWS/CEL 10-33-18] }\end{array}$ & OK209912 \\
\hline & $\begin{array}{l}\text { Bermuda, south shore Bermuda I., Horseshoe Bay grotto, 20.I.2012, C. Schneider, } \\
\text { C. Lane \& T. Popolizio; BDA0678 [CWS/CEL/TRP 12-20-5] }\end{array}$ & OK209913 \\
\hline & $\begin{array}{l}\text { Bermuda, south shore Bermuda I., Warwick Long Bay, 10.VI.2012, T. Popolizio; } \\
\text { BDA1168 [TRP/CWS 12-71-3] }\end{array}$ & OK209911 \\
\hline \multirow[t]{6}{*}{ Laurencia dendroidea J.Agardh } & $\begin{array}{l}\text { Bermuda, St. George's I., Whalebone Bay, 21.VIII.2010, C. Schneider, C. Lane \& } \\
\text { T. Popolizio; BDA0225 [CWS/CEL 10-16-11] }\end{array}$ & OK209918 \\
\hline & $\begin{array}{l}\text { Bermuda, Harrington Sound, Tucker's Bay, 24.VIII.2010, C. Schneider, C. Lane \& } \\
\text { T. Popolizio; BDA0430 [CWS/CEL 10-28-1] }\end{array}$ & OK209914 \\
\hline & $\begin{array}{l}\text { Bermuda, north shore Bermuda I., Spanish Point Park, 25.VIII.2010, C. Schneider, } \\
\text { C. Lane \& T. Popolizio; BDA0510 [CWS/CEL 10-33-24] }\end{array}$ & OK209915 \\
\hline & $\begin{array}{l}\text { Bermuda, north shore Bermuda I., Spanish Point Park, 25.VIII.2010, C. Schneider, } \\
\text { C. Lane \& T. Popolizio; BDA0511 [CWS/CEL 10-33-23] }\end{array}$ & OK209916 \\
\hline & $\begin{array}{l}\text { Bermuda, south shore Bermuda I., Horseshoe Bay grotto, 20.I.2012, C. Schneider, } \\
\text { C. Lane \& T. Popolizio; BDA0676 [CWS/CEL/TRP 12-20-4] }\end{array}$ & OK209919 \\
\hline & $\begin{array}{l}\text { Bermuda, south shore Bermuda I., Grape Bay Beach, 7.II.2012, T. Popolizio; BDA0817 } \\
\text { [TRP/CWS 12-30-10] }\end{array}$ & OK209917 \\
\hline \multirow[t]{6}{*}{ Laurencia microcladia Kützing } & $\begin{array}{l}\text { Bermuda, south shore Bermuda I., Capt. Williams' Bay, 15.I.2012, C. Schneider, } \\
\text { C. Lane \& T. Popolizio; BDA0523 [CWS/CEL/TRP 12-2-2] }\end{array}$ & OK209922 \\
\hline & $\begin{array}{l}\text { Bermuda, Spanish Point Park, 18.I.2012, C. Schneider, C. Lane \& T. Popolizio; } \\
\text { BDA0599 [CWS/CEL/TRP 12-11-3] }\end{array}$ & OK209923 \\
\hline & $\begin{array}{l}\text { Bermuda, south shore Bermuda I., Cox's Bay, Ariel Sands, 31.I.2012, T. Popolizio; } \\
\text { BDA0769 [TRP/CWS 12-27-9] }\end{array}$ & OK209924 \\
\hline & $\begin{array}{l}\text { Bermuda, north shore Bermuda I., Shelly Bay, Bowen Point, 15.II.2012, T. Popolizio; } \\
\text { BDA0855 [TRP/CWS 12-33-5] }\end{array}$ & OK209921 \\
\hline & $\begin{array}{l}\text { US Virgin Islands, St. Croix, Turtle Deli Beach, 20.XI.2013, C. Lane, T. Popolizio \& } \\
\text { E. Salomaki; STX079 [CEL/TRP 13-26-2] }\end{array}$ & OK209925 \\
\hline & $\begin{array}{l}\text { US Virgin Islands, St. Croix, Split Bay, 22.XI.2013, C. Lane, T. Popolizio \& E. Salomaki; } \\
\text { STX150 [CEL/TRP 13-32-1] }\end{array}$ & OK209920 \\
\hline
\end{tabular}

